Sequence Development on a Sediment-Starved, Low Accommodation Epeiric

Carbonate Ramp: Silurian Wabash Platform, USA Mid-continent During Icehouse to Greenhouse Transition

\author{
Alison Elizabeth Spengler \\ Thesis submitted to the faculty of the \\ Virginia Polytechnic Institute and State University in \\ partial fulfillment of the requirements for the degree of \\ Master of Science \\ In \\ Geosciences \\ J. Fred Read, Chair \\ Kenneth A. Eriksson \\ Shuhai Xiao \\ August 28, 2007 \\ Blacksburg, Virginia
}

Keywords: Silurian, Wabash Platform, Indiana, sequence stratigraphy, carbonate

(C) Alison E. Spengler, 2007 


\title{
Sequence Development on a Sediment-Starved, Low Accommodation Epeiric Carbonate Ramp: Silurian Wabash Platform, USA Mid-continent During Icehouse to Greenhouse Transition
}

\author{
Alison Elizabeth Spengler
}

\begin{abstract}
A study of 12 cores and 2 wells with cuttings through the Silurian (444 to 416 m..y.) succession of the Wabash Platform, Indiana was done to establish the high resolution sequence stratigraphy of a sediment-starved low-latitude epeiric sea platform during the transition from Ordovician icehouse to Devonian greenhouse. The Wabash Platform (approximately 200,000 square $\mathrm{km}$ area) is bounded to the north by the Michigan Basin, to the east by the Appalachian Basin, and passed to the southwest into the Vincennes Basin, which was open to the ocean.

Facies developed include: crinoidal grainstone-packstone sheets (updip shoals), buildup facies (stromatactis wackestone - lime mudstone, below storm wave-base settings; stromatoporoid skeletal wackestone - floatstone, storm wave-base to fairweather wave-base; and crinoidal rudstone to packstone; flank facies); non-cherty, skeletal packstone, wackestone, mudstone (sub-fair-weather- to storm wave-base); and cherty, skeletal wackestone - mudstone and variably argillaceous carbonate mudstone (below storm wave-base).

Eight thin sequences (1.3 to $4 \mathrm{~m} . \mathrm{y}$. duration) occur and range from $2 \mathrm{~m}$ to $10 \mathrm{~m}$, with the upper two sequences up to $20 \mathrm{~m}$ downdip; most of the sequences can be
\end{abstract}


correlated to global cycles. Except for the lower three disconformity-bounded sequences, most sequences are relatively conformable and lack well defined sequence boundaries or subaerial exposure surfaces. The most easily mapped surfaces are the transgressive surfaces, given that the correlative conformities are cryptic. Lowstand system tracts probably include downdip grainy facies and the deep ramp seaward of updip late highstand deposits. Transgressive systems tracts are upward deepening, upward fining carbonate units, some of which become more argillaceous and silty upward. This contrasts with the usual association of clastic-prone units with lowstand to early transgressive systems tracts. Highstand systems tracts are subtly upward coarsening from carbonate mudstone to skeletal wackestone/packstone and rarely skeletal grainstone. During deposition of the uppermost two sequences, mudmound barrier banks grew upward into shallow water buildups to form a discontinuous raised rim ( $40 \mathrm{~m}$ relief) to the ramp.

Even though subsidence rates were very low $(<1 \mathrm{~cm} / \mathrm{k} . \mathrm{y}$.$) , the low sedimentation$ rates $(0.3 \mathrm{~cm} / \mathrm{k}$.y. to $0.8 \mathrm{~cm} / \mathrm{k}$.y.) generally prevented the seafloor from building to sea level except for the basal three sequences in which Early Silurian third order glacioeustacy generated disconformable boundaries. Thus the ramp remained subtidal through most of the relatively ice-free greenhouse later Silurian except over the buildups which locally shallowed to sea level. Parasequence development in high accommodation settings elsewhere in North America are compatible with the transition from moderate ice-sheets to an ice free world. However, this is poorly expressed on the Wabash Platform due to the dominantly deeper subtidal setting. The Silurian provides a window into climate change from a global cool period to global hothouse, which may have 
implications for understanding future climate change. 


\section{ACKNOWLEDGEMENTS}

This Master's thesis would not have been possible without the help of friends, colleagues, and family. First, I would like to thank Fred Read for exposing me to the wonderful world of carbonates, and for being both a peer and a friend. I would also like to thank my graduate committee, Kenneth Eriksson and Shuhai Xiao for their valuable input and instruction. Additionally, I would like to thank Chance Amos and Ben Roth for assistance in the field and in the Carbonate Lab. My time at Virginia Tech would not have been complete without the friendship of my fellow graduate students in the Department of Geosciences. The office and technical staff has been invaluable and is thanked for all their assistance.

This work has benefited greatly from grants from the American Association of Petroleum Geologists, National Science Foundation and Eastern Section American Association of Petroleum Geologists. A special thanks for the personnel at the Indiana Geologic Survey for providing access to data and materials, especially Brian Keith, John Droste, Charlie Zuppann and Sherry Cazee. Also, thank you to Mark Kleffner, Ohio State-Lima, for assistance with the conodont data, Dave Harris at the Kentucky Geological Survey and Don Mikulic at the Illinois State Geological Survey. Finally, I thank my parents for support and encouragement through the years. 


\section{CONTENTS}

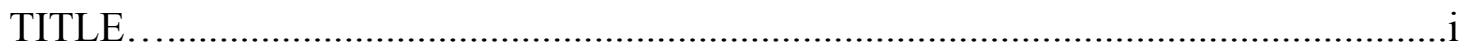

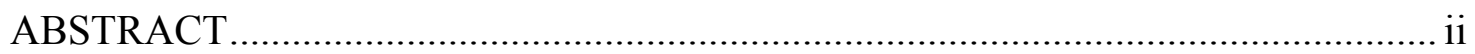

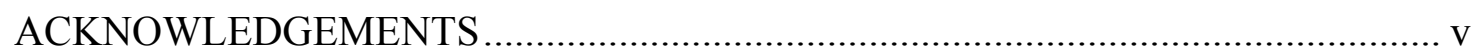

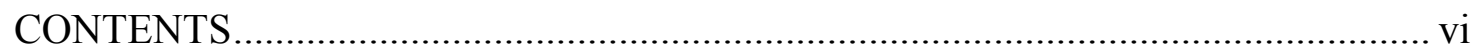

LIST OF FIGURES .................................................................................... viii

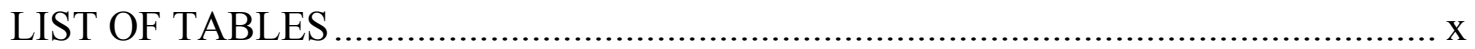

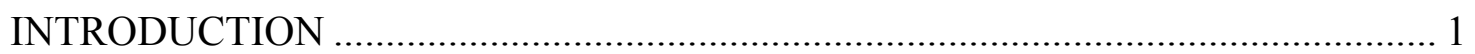

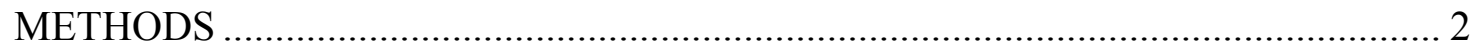

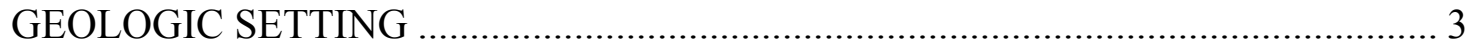

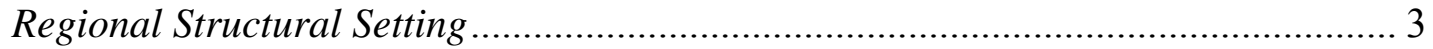

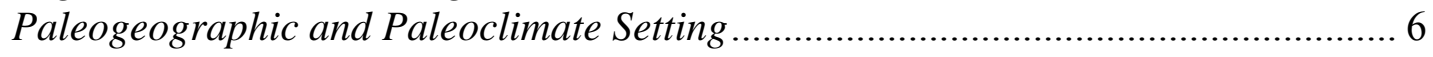

Stratigraphic Framework................................................................................ 7

WABASH PLATFORM FACIES ...................................................................... 10

Crinoid Grainstone and Packstone Sheets ................................................... 10

Buildup Facies ....................................................................................... 11

Non-cherty, Skeletal Wacke-Packstone, Wackestone to Mudstone ..................... 13

Cherty, Skeletal Wackestone - Carbonate Mudstone ...................................... 14

Variably Argillaceous Carbonate Mudstone..................................................... 15

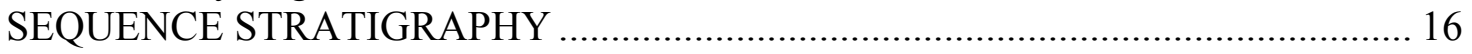

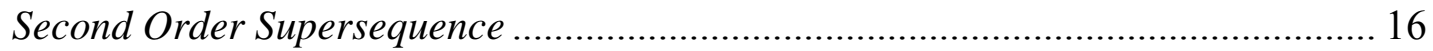

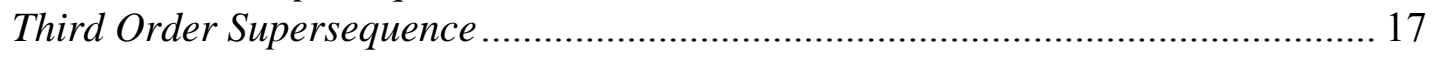

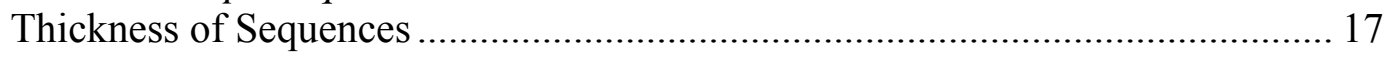

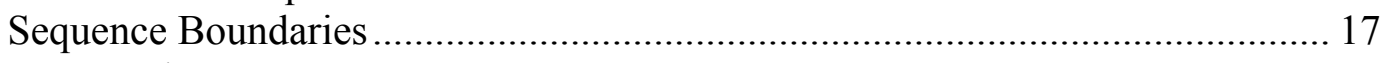

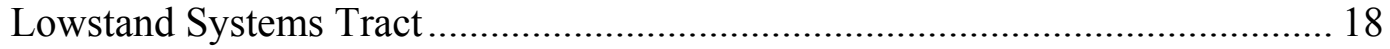

Transgressive Systems Tract......................................................................... 19

Maximum Flooding Surface ....................................................................... 20

Highstand Systems Tract ........................................................................ 20

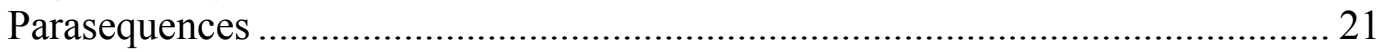

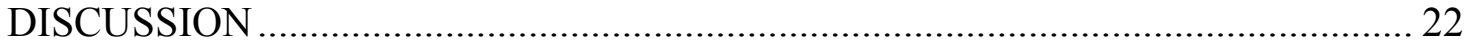

Sedimentation Rates and Duration of Sequences .............................................. 22

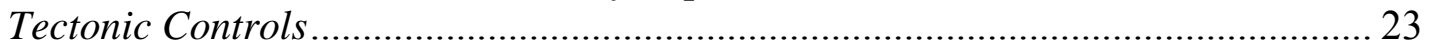

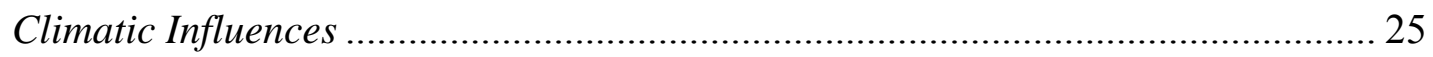

Winds and Sources of Marine Waters …........................................................ 25

Climate and Quasi-estuarine and Anti-estuarine Circulation ............................ 27

Glacial Versus Non-glacial Climate Modes ................................................. 28

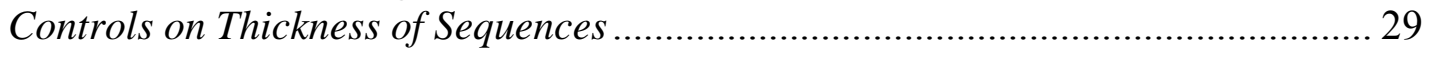

Controls on Eustacy and Sequence Boundary Development .................................. 30

Controls on Lowstand Systems Tract Development................................................ 34

Controls on Transgressive Systems Tracts Development ....................................... 35

Controls on Highstand Systems Tract Development ............................................ 37

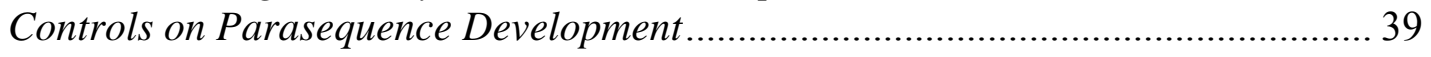

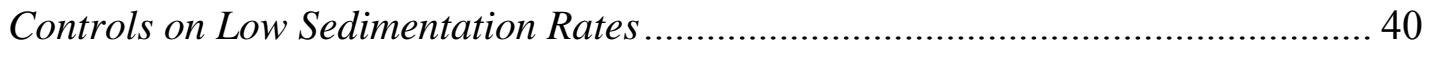

Isotopic Evidence for Eustatic Control on Sequences ......................................... 42

Controls on Development of Bank Complex ....................................................... 44 


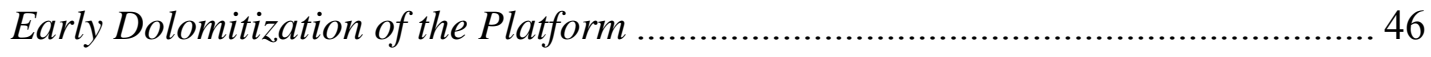

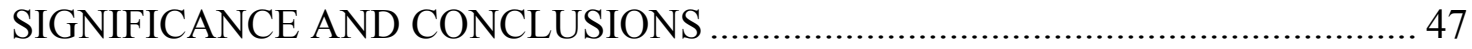

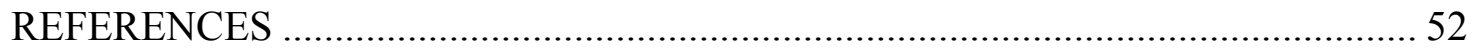

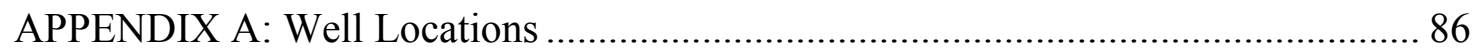

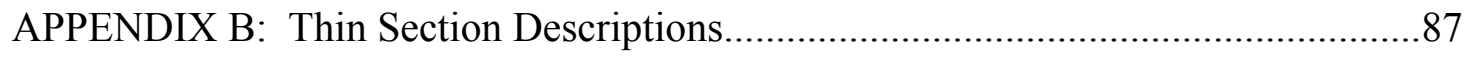

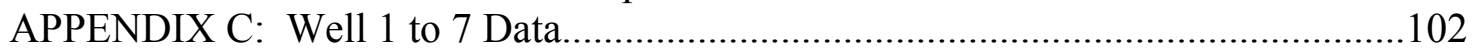

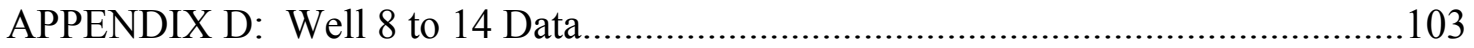

APPENDIX E: North-South Core-Based Cross Section............................................104

APPENDIX F: East-West Core-Based Cross Section............................................... 105

APPENDIX G: North-South Core-Based Cross Section with Well Data....................106

APPENDIX H: East-West Core-Based Cross Section with Well Data......................107 


\section{LIST OF FIGURES}

Figure 1. Regional structure map, Wabash Platform, mid-continent, U.S.A. Location in eastern U.S. shown on inset map.....................................................66

Figure 2. Isopach map of Silurian strata, Indiana (modified from Ault et al., 1992).

Reef trends (stippled), Vincennes (proto-Illinois) Basin, Michigan and

Appalachian basins (dashed) and flexure (dash-dot line) are shown.

Figure 3A. Paleogeography of Laurentia during Early Silurian.................................68

Figure 3B. Paleogeography of Laurentia during Late Silurian..................................68

Figure 4. Chronostratigraphic chart showing graptolite and conodont zones, formational stratigraphy (Nicoll and Rexroad, 1968; Becker, 1974; Rexroad et al., 1978; Rexroad, 1980; Sieverding, 1981; Shaver, 1984; Kleffner, 1998; Mikulic and Kluessendorf, 2001), timing of glacial deposits (Crowell, 1983; Caputo and Crowell, 1985; Grahn and Caputo, 1992; Caputo; 1998; Harris et al., 1998), carbon-isotope excursions from (Saltzman, 2001, 2002) and Indiana sequences, this study (numbering of Wabash Sequences tentative).

Figure 5. Depositional profile showing the facies distribution on the Wabash Platform, Indiana.

Figure 6. Map showing structural drape of Middle Devonian unit over the top of the Silurian carbonate; this map mimics the remnant topography on the platform at the end of the Silurian (Droste and Shaver, 1980).

Figure 7. Slab photographs of facies.............................................................. 73 
Figure 8. Thin section photographs of facies

Figure 9. Regional north-south sequence stratigraphic cross section showing interpretive, vertical and lateral facies succession based on continuous core data. .75

Figure 10. Regional west-east sequence stratigraphic cross section showing interpreted vertical and lateral facies succession, based on continuous core data.

Figure 11. Global and local sea level curves (Johnson, 1996), compared with Indiana sea level cycles (this study) .79

Figure 12A. Circulation models for quasi-estuarine, which dominates during humid, cool climates in the Early Silurian.

Figure 12B. Circulation models for anti-estuarine, which dominated during arid, warmer climates in the later Silurian (Witzke, 1987) 81

Figure 13A. Schematic origin of bounding surfaces. (A) Sea-level versus time plot showing origin of disconformable sequence boundaries which dominate sequences WS-1 to 3. They formed on updip parts of the platform that was relatively high with respect to the sea level lowstand; sea level changes were some tens of meters .82

Figure 13B. Schematic origin of bounding surfaces. Mapped conformable boundaries in sequences WS-4 to 8 on the Wabash platform probably developed on shallowest water facies at tops of sequences (lowstand deposits) and thus they represent transgressive surfaces. .82

Figure 13C. Schematic origin of bounding surfaces. In the basin where the data is 
limited to cuttings, the correlative conformities were placed arbitrarily

beneath the shallowest water facies...................................................8 82

\section{LIST OF TABLES}

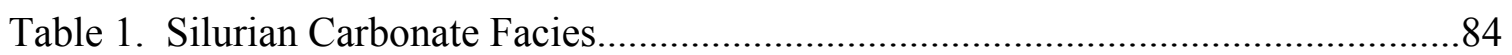

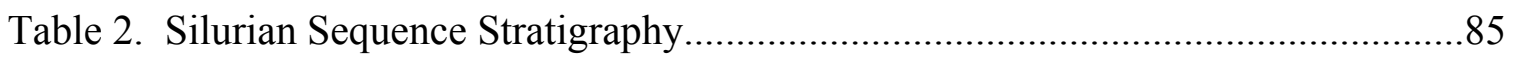




\section{INTRODUCTION}

The Silurian was considered part of the long-term Paleozoic greenhouse climate which only contained brief glaciations in the Late Ordovician and Late Devonian (Fischer, 1983). Recent data from high latitude Gondwanan sites suggest that glaciation continued into the Early Silurian, before global climate warmed to greenhouse conditions (Brenchley et al., 1994; Caputo, 1998; Caputo and Crowell, 1985; Crowell, 1983; Frakes et al., 1992; Grahn and Caputo, 1992; Husseini, 1990; Powell et al., 1994). The later Silurian on Laurentia was extremely warm and dry, with cyclic evaporites in the Michigan and Appalachian Basins (Droste and Shaver, 1977; Mesolella et al., 1976; Shaver et al., 1978; Witzke, 1990). Thus, the Silurian record likely captures the effects of an approximately 20 m.y. transition from a global cool phase into a very warm arid phase. However, this record on the Wabash Platform, Indiana, was strongly influenced by low accommodation and low accumulation rates (Heidlauf et al., 1986).

To study this, continuous cores of the Silurian Wabash Platform, housed at the Indiana Geological Survey, were used to define facies stacking and high resolution sequence stratigraphy of the Wabash Platform carbonates, Indiana (Fig. 1, 2). This study shows the influence that Early Silurian glaciations had on sequence boundary development, compared with those of the relatively ice free, later Silurian. The scarcity of clearly recognizable subaerial surfaces and the dominant subtidal setting complicated the core based sequence analysis and selection of regionally mappable bounding surfaces.

Even allowing for the observed decrease of sedimentation rates with increasingly longer duration (Sadler, 1981), the Wabash Platform had extremely low accumulation rates $(<1 \mathrm{~cm} / \mathrm{k} . \mathrm{y}$.$) . In spite of very low accommodation rates on the platform, the very$ 
low sedimentation rates maintained the dominantly low energy, muddy subtidal ramp setting for most of the Silurian. Factors leading to later Silurian buildups that formed a discontinuous raised rim to the ramp (Droste and Shaver, 1980) are examined. The low sedimentation rates are examined in terms of distance from open ocean, very low tides, little wave energy, large platform size, long residence time of waters and circulation within the epeiric sea (Allison and Wright, 2005; Bosence and Waltham, 1990; Demicco and Hardie, 2002; Witzke, 1987).

\section{METHODS}

Twelve slabbed continuous cores and cuttings from two wells through the Silurian succession, which are housed at the Indiana Geological Survey, were logged. The wells are located with section, township and range (Appendix A). Data from the logged cores were plotted at a scale of 10 feet per inch (core sheet format by Aus Al-Tawil). The core data were plotted in terms of mineralogy, sedimentary structures, extended Dunham classification, grain types, color, grain size, and fossil types versus core depth. Formation picks of drillers were used as preliminary picks to guide stratigraphic correlation. Core logs were color-coded for facies-type. Lithologic markers such as silty argillaceous carbonates were used to help correlate between sections using the lithologic core-logs and electric $\log$ where available. Unfortunately, modern wireline logs were not available for the wells used, so resistivity logs where available, were used instead. Cores were stained locally to differentiate limestone, dolomite and siliciclastic minerals. Stained thin sections of the various facies were examined under the petrographic microscope. For the two wells with cuttings, coarse fraction (1-2mm) of the cuttings for each sample interval (typically 10 feet) were washed, acid etched $(2.5 \% \mathrm{HCl})$, stained with Alizarin Red S, 
and logged using a binocular microscope (cf. Wynn and Read 2006).

Because of sparse area coverage, east-west and north-south cross sections were created by projecting wells onto north-south and east-west cross section lines, by tracing along isopach contours. On the inner ramp, the wells were hung from the SilurianDevonian unconformity. Over the Terre Haute Bank, relief of the buildups above the surrounding platform defined by structural drape of the Middle Devonian over the buildups was used to hang the wells, because this represented the depositional relief at the end of the Silurian (Droste and Shaver, 1980). Rare cores which did not extend to the top Silurian were hung from the Ordovician-Silurian boundary. Interpretive sequence stratigraphic cross sections showing lithofacies distribution, maximum flooding surfaces and sequence boundary or correlative conformities were constructed from the core data. The formations and sequences for this study were correlated to updated conodont zones (Kleffner, 1998; per. com), but to compare the Silurian Wabash Platform sequences with the Silurian global and local sea level curves (Johnson, 1996), it was redrafted to match with older conodont zonations from Johnson (1996).

\section{GEOLOGIC SETTING}

\section{Regional Structural Setting}

The study area is located within the Indiana-southern Illinois portion of the Wabash Platform (Figs. 1, 2), which extends from eastern Iowa to western Ohio, covering an area of 200,000 square km (Shaver et al., 1978). The Wabash Platform is bounded to the southwest by the proto-Illinois Basin (termed the Vincennes Basin), to the north by the Michigan Basin, and to the east, by the Appalachian Basin (Becker and Droste, 1978; Droste and Shaver, 1987b; Seale, 1985). The Vincennes Basin was a large 
oval-shaped intracratonic basin bounded the west by the Ozark Dome and to the east and southeast by the Jessamine and Nashville Domes on the Cincinnati Arch. The Pascola Arch borders the Vincennes Basin to the southwest, and is a Mesozoic feature not active during the Paleozoic. The Cincinnati Arch and the Ozark Dome were effective sedimentation barriers in the mid-Paleozoic, with the Cincinnati Arch inhibiting terrigenous sediment influx from the Appalachians to the east, while the Ozark Dome formed a sediment barrier to the west, starving the Vincennes Basin (Seale, 1985; Shaver et al., 1978). The Cincinnati Arch and the Findlay Arch are Paleozoic features that approximately parallel the Appalachian orogen (Faill, 1997b). The Kanakee Arch lies on the Wabash Platform further to the northwest (Becker, 1974). The lack of an effective southern barrier to the Vincennes Basin in the Silurian allowed open marine waters onto the Wabash Platform, and prevented circulation from becoming restricted, and so evaporites that typify the Michigan and Appalachian basins did not develop here (Droste and Shaver, 1987b; Droste et al., 1985; Shaver et al., 1978).

The seaward margin of the Wabash Platform is bordered by pinnacle buildups of the Terre Haute and Fort Wayne banks, which border the Vincennes and Michigan basins respectively. These form elevated but discontinuous rims to the Wabash Platform, which had a deeper subtidal platform interior (Fig. 2; Becker and Droste, 1978; Shaver et al., 1978). The Wabash Platform, although rimmed by broad banks capped by pinnacle buildups, is a ramp because it lacked a shelf slope break, facies sequences are ramp-like, "reef" trends are discontinuous, and slopes are gradual (less than $1^{\circ}$ ) over hundreds of miles (Ault et al., 1992; Coburn, 1986; Kruger, 1993; Tollefson, 1978).

The proto-Illinois Basin formed over a failed-rift triple junction (Burke and 
Dewey, 1973) in response to latest Proterozoic break-up of Rodinia. Initial lateProterozoic subsidence resulted from rift-related extension (greater than $10 \mathrm{~cm} / \mathrm{k} . \mathrm{y}$. accumulation rates), while later (Cambrian to Middle Ordovician) it was controlled by thermal subsidence $(1.5-7.5 \mathrm{~cm} / \mathrm{k} . \mathrm{y}$. accumulation rates $)$ and/or sediment- and waterloading (Heidlauf et al., 1986; Kolata and Nelson, 1990). Subsidence slowed markedly into the middle and late Paleozoic $(0.6-1.2 \mathrm{~cm} / \mathrm{k} . \mathrm{y}$. accumulation rates). The protoIllinois Basin had a phase of slightly higher subsidence in the Early Silurian, which slowed almost to zero into the Late Silurian. Water depths in the Illinois Basin were shallow from the latest Ordovician into Early Silurian, but deepened to $300 \mathrm{~m}$ by the Middle Silurian and then shallowed into the Early Devonian. The regional crosssections, although modified by post-Silurian erosion and beveling of the inner platform, suggest down-to-basin flexure during the Ludlow and Pridoli.

Following Late Ordovician (Taconic) arc-continent collision, tectonic highlands were developed along the eastern margin of Laurentia, including eastern Greenland (Fig. 3A; Rodgers, 1970). Whether the arc was breached, allowing influx of waters is not clear, but there appears to have been an opening in the Gaspe Peninsula region, Quebec (Bourque, 2001; Bourque et al., 2000). At this stage, Baltica lay to the east of the Northern Appalachians, separated by the Iapetus Ocean (Cocks and Torsvik, 2002; Golonka, 2002; Scotese and McKerrow, 1990). In the later Silurian, Iapetus Ocean in the Northern Appalachians closed, due to collision of Baltica and Laurentia (Salinic disturbance; Boucot, 1962; Cawood et al., 1995; Cunning et al., 1990; Torsvik et al., 1996) . This effectively raised large tectonic highlands (Scandian Orogeny) decreasing influx of ocean waters from the east onto Laurentia (Fig. 3B). 
Collisional tectonics in the Appalachians in the later Ordovician (Taconic) and Silurian caused subsidence within the Vincennes and Michigan basins and the Wabash Platform (Quinlan and Beaumont, 1984) with uplift on the arches. The Baltica-Laurentia collision, as well as collision of Avalonia-Laurentia in the Appalachians may have been responsible for the later Silurian pulse of subsidence (Ettensohn, 1994; Goodman and Brett, 1994).

\section{Paleogeographic and Paleoclimate Setting}

During the Silurian, North America was rotated approximately $45^{\circ}$ clockwise from its present day position and the Vincennes Basin was located at approximately $20^{\circ} \mathrm{S}$ latitude (Fig. 3A). By the end of the Silurian it had moved to approximately $25^{\circ} \mathrm{S}$ (Fig. 3B; Mikulic, 1990; Scotese et al., 1979; Scotese and McKerrow, 1990). Thus the bulk of Laurentia lay in the trade wind belt dominated by easterlies, which is supported by modeling studies (Moore et al., 1994; Witzke, 1987). Conceptual models of surface currents within the Iapetus Ocean during the Late Ordovician and Early Silurian indicate that south-westerly moving currents moved along the eastern margin of Laurentia (Herrmann et al., 2004).

The Silurian was previously thought to be strictly greenhouse (Fischer, 1983), but is now considered to be part of the later Ordovician-Early Silurian cool mode (Frakes et al., 1992). This glacial cool mode is the third most widespread and intense glacial period of the Phanerozoic (Frakes et al., 1992). It was characterized by a major latest Ordovician glaciation, and three glaciations in the Early Silurian Llandoverian to Wenlockian (Caputo, 1998; Caputo and Crowell, 1985; Crowell, 1983; Crowell, 1999). The modeling studies suggest the Late Ordovician-Early Silurian glaciations developed 
as a result of $\mathrm{CO}_{2}$ drawdown by silicate weathering (orogenic highlands), organic carbon burial, drifting of Gondwana over the South Pole, decrease in equator-polar heat transfer by meridional overturning, coupled with long term sea level fall (Brenchley et al., 1994; Herrmann et al., 2004; Melchin and Holmden, 2006). Major ice sheets disappeared by the end-Wenlock. Modeling studies using approximately 4 times present atmospheric $\mathrm{CO}_{2}$ suggest that any glaciations in the Wenlock (and later Silurian) would have been confined to higher altitudes with summer temperatures near freezing, thus the ice sheets would have been small and associated with alpine or piedmont glaciers (Moore et al. 1994). Thus the Middle to Late Silurian, may have been transitional into Early to Middle Devonian greenhouse paleoclimate.

The Silurian Llandovery interval was dominated by a humid climate, while the later Wenlock through the end of the Silurian (Pridoli) had a more arid climate (Bickert et al., 1997; Cramer and Saltzman, 2007; Frakes et al., 1992; Witzke, 1990). Climate modeling for the Wenlock shows that the subtropical belt was a zone of negative precipitation minus evaporation (Moore et al 1994). Also, the precipitation fell on the eastern margin of landmasses and highlands, thus creating a rain shadow effect for much of eastern Laurentia. This later Silurian drying caused evaporite deposition in the Michigan and Appalachian basins, with desert conditions on adjacent land areas on the Jessamine Dome and in present day Wisconsin and Missouri (Droste and Shaver, 1977; Shaver et al., 1976; Witzke, 1990). This change from humid to arid conditions at all scales, had a profound effect on circulation, with quasi-estuarine during humid phases and anti-estuarine circulation during arid phases (Witzke, 1987).

\section{Stratigraphic Framework}


The chronostratigraphy of the Silurian is given in Figure 4, with ages based on conodonts (Becker, 1974; Kleffner, 1998; Mikulic and Kluessendorf, 2001; Nicoll and Rexroad, 1968; Rexroad, 1980; Rexroad et al., 1978; Sieverding, 1981). The Silurian succession unconformably overlies latest Ordovician units of the Manquoketa Group, a gray shaly limestone or dolomitic limestone (Becker, 1974). However, the unconformity in the cores examined lack obvious subaerial features. The Silurian succession thins updip to 30 to $40 \mathrm{~m}$ into the outcrop belt. It thickens downslope to $120 \mathrm{~m}$ both to the west and north. This thickening is most rapid over a flexure bordering the Jessamine Dome (Fig. 2), and is mainly confined to the post-Louisville (post-early Ludlow) units which are absent updip.

The basal Silurian unit updip is the Llandovery Brassfield Limestone (1 to 3 meters thick), a medium to coarse grained skeletal limestone and dolomite (Fig. 4). It is overlain by and thickens downdip (westward) into the Sexton Creek Limestone (0 to 15 $\mathrm{m}$ thick), a gray, fine- to medium- grained cherty, locally dolomitic limestone. Both units are in the Distomodus kentuckyensis assemblage zone (Becker, 1974; Nicoll and Rexroad, 1968; Rexroad, 1980; Sieverding, 1981). The overlying Lee Creek Member is a siliceous dolomite unit in the upper Brassfield Limestone, with Ozarkodina celloni assemblage zone conodonts, indicating a significant hiatus at its base (Fig. 4; Kleffner, 1995; Nicoll and Rexroad, 1968; Sieverding, 1981).

The early Wenlock Osgood Shale (3 to 9 meters thick) disconformably overlies the Brassfield Limestone/Lee Creek Member, with a relatively short hiatus (Fig. 4). It is a gray, fine- to medium-grained, shaly, variably dolomitic limestone (Becker, 1974; Perry and Hattin, 1960; Rexroad, 1980; Seale, 1985; Sieverding, 1981). The early to middle 
Wenlock Laurel Member ( 9 to 12 meters thick updip, 15 to 25 meters thick downdip) is locally conformable on the Osgood Shale (Fig. 4). It is a light gray to tan, fine- to coarsegrained, sparsely to very fossiliferous, variably cherty, dolomitic limestone or dolomite (Shaver et al., 1976; Sieverding, 1981).

The late Wenlock Waldron Shale (1 to 6 meters thick) conformably overlies the Laurel Member and is greenish-gray to bluish-gray, nodular bedded, fine- to mediumgrained, calcareous to dolomitic shale that thins downdip. The upper transition boundary with the late Wenlock-early Ludlow Louisville Limestone cannot be defined biostratigraphically due to the lack of diagnostic fossils (Becker, 1974; Rexroad, 1980; Seale, 1985). The conformably overlying Louisville Limestone (0 to 20 meters thick) is a light to medium brown and gray, fine- to medium-grained, variably fossiliferous limestone and dolomitic limestone that is shaly locally. The Osgood Shale, Laurel Member, Waldron Shale and the Louisville Limestone all grade downdip into the Vincennes Basin into the Wenlockian St. Clair Limestone (Fig. 4; Becker, 1974; Sieverding, 1981; Seale, 1985).

The 0 to 55 meter thick mid to late Ludlow Mississinewa Shale Member of the Wabash Formation conformably overlies the Louisville Limestone and is a greenish-gray, fine grained dolomitic siltstone which contains thin beds of olive-gray, fine- grained limestone (Becker, 1974). It grades downdip into the Vincennes Basin into the Moccasin Springs Formation (Becker, 1974; Lane and Ausich, 1995; Pollock and Rexroad, 1973;

Seale, 1985; Textoris and Carozzi, 1964). Within the basin, the St. Clair and Moccasin Springs contact maybe time transgressive (Droste and Shaver, 1987b). The late LudlowPridoli Liston Creek Limestone Member (up to 50 meters thick) of the Wabash 
Formation, is a yellowish to olive-gray, fine- to medium-grained, cherty limestone or dolomitic limestone (Becker, 1974).

The mid Ludlow-Pridoli Huntington Lithofacies, refers to any reef or reef-like carbonate within the Wabash Formation (Mississinewa Shale and Liston Creek Members) (Becker, 1974; Pinsak and Shaver, 1964; Shaver et al., 1978). The reefs have been found in units as old as the Wenlockian Waldron Shale (Textoris and Carozzi, 1964). Unconformities are not found in the middle to upper Silurian (Tollefson, 1978). The Silurian-Devonian contact is conformable in the Vincennes Basin, but updip on the Wabash Platform, the contact becomes increasingly unconformable with siliclastics infiltrating karstic cavities (Becker, 1974; Droste and Shaver, 1987b).

\section{WABASH PLATFORM FACIES}

Silurian carbonate facies on the Wabash Platform are summarized in Table 1 and their distribution is shown on an idealized depositional profile (Fig. 5). The depositional thinning and thickening on the Terre Haute Bank is shown in Figure 6. Slab and thin section photographs are shown in Figures 7 and 8. The regional facies distribution is shown on the two cross-sections (Figs. 9, 10). Because the Silurian sequences have relatively subtle lithologic changes dominated by muddy carbonates, and many of the Dunham textures are intimately admixed, we have used wacke-packstone for skeletal packstone intimately admixed with wackestone, and wacke-mudstone for intimately admixed skeletal-poor wackestone and mudstone. This allowed recognition of subtle upward-deepening and upward-shallowing trends in sequences.

\section{Crinoid Grainstone and Packstone Sheets}

Crinoid grainstone and packstone units are 3 to 5 meters thick, massive, sheet- 
like, medium gray, units with rare wavy argillaceous stringers, and occur at the base of the section on the inner platform (Figs. 9, 10). They are medium- to very coarse-grained, composed of moderate- to well-sorted whole and fragmented echinoderm, lesser brachiopod, ostracod, trilobite, mollusk, bryozoan, rare glauconite grains and locally, micritized grains. Lime mud is rare to absent, and may be dolomitized.

These facies formed in crinoid-dominated, open marine, wave- and currentagitated shoal settings, indicated by scarcity of lime mud. The lack of mechanical sedimentary structures suggests intense burrow homogenization.

\section{$\underline{\text { Buildup Facies }}$}

Buildup facies of the Wabash Platform have been described by Lowenstam (1950; 1957) Textoris and Carozzi (1964), Shaver (1974; 1987), Mikulic and Klussendorf (1994) and others. The Terre Haute Bank (Fig. 6) consists of a broad bank (50 km wide) cut by two broad passes. It thickens locally due to numerous pinnacle buildups. The Fort Wayne Bank to the north was not part of the study, although a core intersected an isolated buildup behind the bank. The buildups are dominated by stromatactis-bearing wackestone and lime mudstone, stromatoporoid skeletal floatstone and wackestone, and very coarse crinoidal rudstone to packstone. Carbonate mudstone and skeletal wackestone of the regional platform interfinger with or extend onto buildup facies.

Stromatactis-bearing wackestone and lime mudstone: These form units 1 to 15 meters thick, that are light gray, massive or bedded. At bases of buildups, Stromatactis is parallel to the horizontal layering of units, but higher in the buildups, Stromatactis dips conform to the mound morphology with dips up to $30^{\circ}$ in core. They are composed of fine- to medium-grained, poorly to moderately sorted whole and fragmented 
echinoderms, stick bryozoans and lesser brachiopod, mollusk, ostracod and Halysites debris. Stromatactis cavities are lined with marine, isopachous bladed-calcite cement. Most matrix is completely dolomitized, although calcisiltite is a common matrix in undolomitized facies elsewhere on the platform (Textoris and Carozzi, 1964).

These stromatactis-bearing wackestone facies formed in low energy settings, below storm wave-base. The change from parallel, horizontally layered-stromatactis up into dipping stromatactis indicates increase in mound relief with buildup growth. Scattered coral debris and the lack of terrigenous clay indicate that currents periodically winnowed the surfaces of the deeper buildups (Textoris and Carozzi, 1964).

Stromatoporoid skeletal wackestone and floatstone: These are less than 5 meters thick, pale gray to white units generally with inclined stratification. They consist of small platy to sub-spherical stromatoporoids, rare crinoid, brachiopod, ostracod, bryozoan and some fragmented coral (e.g. Favosites and Halysites) with interstitial wacke-mudstone to grainstone, the grainstone being more common in upper parts of some buildups.

Stromatoporoid wackestone to floatstone facies formed by accumulation of scattered in-situ framebuilders along with carbonate sand and mud, in variable energy settings between storm wave-base up into fair-weather wave-base (Shaver and Sunderman, 1989; Textoris and Carozzi, 1964). During this phase, the mounds may have developed into current swept, asymmetric structures, with a high energy wave-influenced windward side and current influenced leeward side (Mikulic and Kluessendorf, 1999; Textoris and Carozzi, 1964).

Crinoidal rudstone, grainstone and packstone: These coarse-grained units commonly form dipping flank beds of buildups. They have abundant gravel-sized and 
lesser sand sized, poorly sorted skeletal debris dominated by crinoids, along with lesser brachiopod, ostracod, bryozoan and solitary corals. Matrix is a dolomitized skeletal siltrich mudstone. Turbid syntaxial overgrowths of marine cement are common on crinoid fragments in mud-lean facies or in shelter cavities.

These facies likely formed in high energy settings, generally on the leeward side of the mounds after they reached wave-base (Mikulic and Kluessendorf, 1994; Textoris and Carozzi, 1964). Skeletal debris produced on mound tops and flanks accumulated as coarse current winnowed aprons on flanks of buildups. Flank beds of allochthonous and autochthonous sediment steepened as the buildups grew laterally (Archer et al., 1980; Shaver and Sunderman, 1989).

\section{Non-cherty, Skeletal Wacke-Packstone, Wackestone to Mudstone}

These units form sheet-like units, 2 to 15 meters thick, on the regional ramp. Wackestone and grain-poor wacke-mudstone commonly grade up into grainy skeletal wacke-packstone caps. Deeper ramp slope sections tens of meters thick in front of buildups, have thick, wackestone-dominated units above cherty carbonates. Wackestonedominated units are widespread both on the deep ramp slope downslope of the buildups and in the platform interior. They are light to dark gray, massive to planar- to wavybedded, with argillaceous stringers and variable amounts of burrowing. Wackepackstones consist of intimately interlayered packstone and wackestone, whereas wackemudstone have admixed wackestone and mudstone fabrics. They are mainly composed of fine- to coarse-grained, poorly to moderately sorted, whole and fragmented echinoderm, lesser brachiopod, mollusk, ostracod, trilobite and bryozoan debris, rare peloids and glauconite. Lime mud is abundant and may be dolomitized. 
On the ramp interior, these skeletal grain-rich to grain-poor wackestone facies formed between fair-weather- and storm wave-base in open marine, low energy, storminfluenced inner platform settings, in waters shallower than 35 meters, decreasing in depth landward (Droste and Shaver, 1987a). This is indicated by presence of lime mud, burrowed units, and relict planar and wavy bedding. These facies probably extended to greater water depths on the ramp slope in front of the Terre Haute Bank. Grain-poor wacke-mudstone formed in the deeper, low energy settings (mud production dominated over grain contribution from the sparse resident benthos), while skeletal wackestone and wacke-packstone formed in shallower areas with more abundant skeletal benthos. Grainrich wacke-packstone formed during shallowing of wackestone lithotopes with more prolific grain production and some winnowing of fines; given that these open marine facies extend far into the platform, water depths would have had to be $>10 \mathrm{~m}$ minimum .

\section{Cherty, Skeletal Wackestone - Carbonate Mudstone}

On the platform, these cherty muddy facies generally occur only in the basal part of the succession (Brassfield-Sexton Creek). They dominate downslope sections in the Vincennes Basin, seaward of the Terre Haute Bank, where they were only sampled from cuttings of wells. The cherty wackestone and mudstone units are 9 to $40 \mathrm{~m}$ thick, and are white to light gray, massive, planar to wavy bedded with variable amounts of argillaceous stringers and burrows. They are composed of rare to abundant fine- to coarse-grained, poorly sorted, whole and fragmented echinoderms, lesser brachiopod, ostracod, and bryozoan debris and nodules of white chert (few percent to $90 \%$ of rock); lime mud is abundant and may be dolomitized, or the matrix altered to microspar.

These facies generally lack storm laminations, and were formed in very low 
energy settings below storm wave base on the gentle upper ramp slope (35 m to $65 \mathrm{~m}$ water depth) and lower ramp slope (65 $\mathrm{m}$ to $100 \mathrm{~m}$ water depth) (Coburn, 1986). Units were burrow-homogenized to form relatively structureless beds. Skeletal production was moderate to low relative to mud production. Much of the silica in the chert probably was from spicules of deeper water, siliceous sponges, and may reflect upwelling and high nutrient levels (c.f. Cramer and Saltzman, 2007).

Variably Argillaceous Carbonate Mudstone

These units are carbonate-prone to highly argillaceous silty (quartz-mica) carbonate mudstone. Units are less than 1 meter to up to 6 meters thick and are sheet-like except where they form wedge-like, deeper lagoon units behind the buildups. They are buff to brownish grey to light gray, planar layered to nodular bedded, with argillaceous dolomitic stringers and minor burrows. They are composed of carbonate mud, fine- to medium-grained, rare echinoderm, brachiopod, ostracod, bryozoan and indeterminate shell debris and are variably dolomitized. Locally, diverse "microbioherms" with reefal assemblages occur in basal parts of argillaceous lime mudstone units of the Waldron Shale (Archer and Feldman, 1986).

Argillaceous carbonate mudstone formed in very low energy settings below storm wave base in the platform interior ( $>35 \mathrm{~m}$ water depths) and over $65 \mathrm{~m}$ depths on the deep ramp (Coburn, 1986; Droste and Shaver, 1987a; Shaver, 1974). Accumulation of abundant lime mud and terrigenous silt and clay outweighed the low skeletal grain production. Although waters may have been normal marine to slightly elevated salinity, low energy and low oxygen levels in a stratified turbid water column with low light could have limited skeletal carbonate production by the resident benthos (Feldman, 1989). 
Sediments were generally burrow-homogenized, expect where low oxygen levels limited burrowing to form laminated units.

\section{SEQUENCE STRATIGRAPHY}

Sequences on the Wabash Platform are summarized in Table 2. The relationship between the formational stratigraphy, sequence stratigraphy, and relative age are shown in Figure 4. The regional north-south cross section traverses the Wabash Platform but does not reach the Fort Wayne Bank in the north (Fig. 9). The regional east-west cross section (Fig. 10) extends from the Jessamine Dome across the Terre Haute bank into the Vincennes Basin.

\section{Second Order Supersequence}

The second order supersequence spans the entire Silurian section and is $30 \mathrm{~m}$ updip and $120 \mathrm{~m}$ downdip. The basal Ordovician-Silurian contact is marked by an unconformity (Becker, 1974). Grainstones of WS-1 and 2 in the Vincennes Basin in Well 7 mark the lowstand systems tract. The transgressive systems tract consists of WS3 to 6 . The maximum flooding surface of the second order supersequence is regionally traceable at the base of WS-7, with deeper water argillaceous mudstones flooding the Wabash Platform. Buildups are common along the platform margin in the highstand systems tract, consisting of WS-7 and 8 and the succession shallows up to the Silurian-

Devonian sequence boundary. The Silurian-Devonian erosional unconformity forms the top sequence boundary on the platform and is increasingly developed to the south and east over the Jessamine Dome, but is conformable downdip in the Vincennes Basin (Becker and Droste, 1978; Droste and Shaver, 1987b). (Becker, 1974; Droste and Shaver, 1982). 


\section{Third Order Supersequence}

In this paper, the third order sequences are informally labeled Wabash-Silurian (sequence WS-1 to 8), in order to avoid prematurely tying these to published sea level curves which differ in detail (Fig. 11; Johnson et al., 1998b; Ross and Ross, 1996). Obvious subaerial surfaces (sequence boundaries) are rare in the Wabash Platform Silurian succession, so sequence boundaries were defined at the turn-around between basinward shifts in facies belts followed by backstepping of facies (Van Wagoner et al., 1988). Thus many boundaries are conformable surfaces that include correlative conformities or even transgressive surfaces (Van Wagoner et al., 1988). Maximum flooding surfaces were picked at the base of the deepest water facies in the sequence, although some picks proved difficult given the relative uniform lithology in some parts of sequences.

\section{Thickness of Sequences}

Sequences WS-1 to 6 have relatively uniform thicknesses across the platform and commonly range from $2 \mathrm{~m}$ to $10 \mathrm{~m}$, and rarely up to $20 \mathrm{~m}$ downdip (sequence WS-6) (Figs. 9, 10). These sequences generally show gentle basinward thickening. Downdip to the west, it is difficult to differentiate sequences WS-1 to 3. Sequences WS-7 and 8 are absent bordering the Jessamine Dome to the southeast, but they thicken markedly to the north and to the west to over $45 \mathrm{~m}$. The thickest sections are commonly associated with mid-ramp buildups, peripheral to the basins.

\section{$\underline{\text { Sequence Boundaries }}$}

Sequence boundaries (and downdip conformable surfaces) were placed at the tops of the coarsest-grained carbonates in the sequences, rather than at bases of clastic-prone 
units, which tend to be deeper water (rather than shallow water nearshore) facies (Feldman, 1989). Regional disconformities are only developed at the base of sequences WS-1 and 2 (Kleffner, 1998; Shaver, 1984). At the base of sequence WS-1, conodont zone $R$. nathoni is missing. There is a significant hiatus at the base of sequences WS-2, where 3 conodont zones appear to be missing: D. staurognathoides, Pt. eopennatus ssp.n.1 and Pt. eopennatus ssp.n.2. There is some evidence of subaerial diagenesis evident at the base of sequences WS-1 and 2. Sequence WS-3 has a local basal disconformity in southeastern Indiana, beneath which there is possible evidence of subaerial exposure (internal sediment filled cavities) and the upper portion of the $P$. celloni zone is missing (Kleffner, 1995; Nicoll and Rexroad, 1968).

The remainder of the boundaries of sequences on the Wabash Platform (sequences WS-4 to 8) are conformable, sharp to gradational surfaces which were placed on top of the shallowest water facies of each sequence on the subtidal ramp, and only locally coincide with hardgrounds or glauconite concentrations. On the basin slope, correlative conformities were arbitrarily placed beneath the shallowest water slope facies.

\section{$\underline{\text { Lowstand Systems Tract }}$}

These likely are represented by relatively shallow water siliciclastic-poor, noncherty wackestone on the deep ramp in front of the Terre Haute Bank in the well cuttings. The grainstone units in the lower part of Well 7 likely are lowstand deposits also. However, they are absent from the more updip Well 6. All the lowstand deposits pass up into cherty, shaly, wackestones and lime mudstones (transgressive to highstand systems tracts). Many of the seaward parts of the shallow water caps on the sequences are likely to be lowstand deposits. 


\section{Transgressive Systems Tract}

The transgressive systems tract cannot be differentiated from the highstand systems tract updip in sequence WS-1, which is grainstone-dominated. In some sequences, the transgressive systems tract is absent and the maximum flooding surfaces coincide with the sequence boundaries (Figs. 9, 10).

Where developed, the transgressive systems tracts are complicated by parasequence development. The most easily recognizable and distinctive transgressive systems tracts are those that contain argillaceous dolomudstones or argillaceous lime mudstones, for example sequence WS-3 (Osgood Shale), sequence WS-6 (Waldron Shale) and sequence WS-7 (Mississinewa Shale). Although previously mapped as "shale", most of these units are argillaceous carbonates. These transgressive systems tracts are deepening upward and fining upward units of wacke-packstone (rare) to wackestone or wacke-mudstone up to burrowed then laminated argillaceous carbonates (Archer and Feldman, 1986; Feldman, 1989). The transgressive systems tract of sequence WS-7 (Wells 3 and 8), has backstepping wackestone to argillaceous carbonate parasequences (Fig. 9).

Carbonate-prone transgressive systems tracts may consist of deepening-upward and fining upward units of skeletal wacke-packstone up into wackestone grading up into carbonate mudstone, as in Wells 8 and 10 in sequence WS-4 and Well 9 in sequence WS3. However, in most transgressive systems tracts, only wackestone up into mudstone is present. There is limited buildup development in the transgressive systems tracts, with the exception of Well 13, where there is a small buildup in the transgressive systems tract of sequence WS-7. However this appears to be part of a shallowing upward succession 
prior to the deepening into the maximum flooding surface, so it may be a part of a smaller scale sequence.

\section{Maximum Flooding Surface}

Maximum flooding surfaces were placed in the upper portion of upwarddeepening lime mudstone or argillaceous mudstone units, above local basal wackestone (Feldman, 1989) and beneath carbonate-prone, more skeletal-rich highstand facies. Deepest water argillaceous mudstones generally are laminated (Archer and Feldman, 1986). Locally, the maximum flooding surface appears to coincide with the sequence boundary where no obvious transgressive systems tract was recognized (e.g. Well 9, sequence WS-5; Well 2, sequence WS-3). Some maximum flooding surfaces are also locally defined by hardgrounds and glauconite concentrations (Well 1, sequence WS-5; Well 9, sequence WS-2). In sequences where more than one parasequence is developed, picking the maximum flooding surface was complicated by the presence of more than one lime mudstone unit, as in sequence WS-6, sequence WS-7 and sequence WS-8.

\section{$\underline{\text { Highstand Systems Tract }}$}

Highstand systems tracts make up more than half of the thickness of sequences and commonly are upward-coarsening units. Simple shallowing-upward trends are complicated by parasequence development. Most highstand systems tracts are skeletal wackestone up into skeletal wacke-packstone and only a few have skeletal packstonegrainstone caps. Highstand facies typically are laminated, grading up into burrowed facies, although locally, laminations may continue to the top of the sequence (Wells 3 and 10, sequence WS-7). More grainy caps of highstand systems tracts initially appear to successively step out basinward from sequence WS-1 through 3, but then appear to be 
stacked vertically (Figs. 9, 10). In the platform interior, upper parts of most highstand systems tracts appear to be skeletal wacke-packstone. Highstand lagoonal mudstone occurs locally behind the regional flexure, bounded updip and downdip by wackestone (Figs. 9, 10).

Significant buildup facies appear to be absent from sequences WS-1 to 6 in the cores studied, but "microbioherms" occur in the Waldron Shale at the base of sequence WS-6 (Archer and Feldman, 1986). Outside the study area, buildups occur as least at low as sequence WS-5 (Shaver and Sunderman, 1983), and within the Vincennes Basin as low as sequence WS-4 (St Clair; Droste and Shaver, 1987b) (Droste and Shaver, 1987b). In this study, only two of the wells were cored through thick buildup facies (Well 5 and 13), while Well 12 cored a small buildup at the top of the Silurian section. In the wells, the buildups have inclined layering with complex interbedding of the buildup facies (Table 1). This made picking parasequences difficult within buildups in the absence of close spaced cores, because it was not clear if the units were randomly interlayered flank beds or were the result of sea level changes. However, broadly shallowing upward trends are evident, and facies grade downslope into muddier facies that coarsen up into wackestone (Textoris and Carozzi, 1964).

In the cuttings, highstand facies in front of the Terre Haute Bank typically are cherty, shaly, poorly fossiliferous wackestone and mudstone. They form units up to $18 \mathrm{~m}$ thick, and are capped by subtle correlative conformities.

\section{$\underline{\text { Parasequences }}$}

Only 1 to 2 parasequences are developed in sequences WS- 1 to 5 , and they are not completely traceable regionally. Most parasequences are three to five meters thick, but 
reach nine to ten meters thick in sequences WS-7 and 8. Sequence WS-6, has 2 to 3 parasequences updip and up to 5 downdip. In sequence WS-7, there are at least 4 parasequences updip and at least 8 downdip. Up to 6 parasequences occur downdip in sequence WS-8.

About half the parasequences show symmetrical upward-deepening to upwardshallowing successions. The remaining parasequences are simple asymmetric shallowing-upward units. Most parasequences consist of slightly deepening wackestone or wacke-mudstone grading into a shallowing-upward and fining-upward mudstone or wackestone capped locally by wacke-packstone. Parasequences generally lack disconformities at their tops, which instead are conformable surfaces on subtidal facies.

\section{DISCUSSION}

\section{Sedimentation Rates and Duration of Sequences}

Based on the duration of the Silurian and the eight sequences developed, their average duration is 2.3 m.y. Based on estimated absolute (Fig. 4), the sequences may range from 1.3 to $4 \mathrm{~m} . \mathrm{y}$, therefore these are third order sequences (c.f. Weber et al., 1995).

Accumulation rates were calculated using the duration of the depositional events (total duration of the Silurian minus the non-depositional events) divided into the preserved sediment thicknesses. These give accumulation rates of $0.2 \mathrm{~cm} / \mathrm{k} . \mathrm{y}$. for the inner ramp, and $0.8 \mathrm{~cm} / \mathrm{k} . \mathrm{y}$. for the Vincennes Basin, values which are similar to the calculated accumulation rates of Heidlauf et al. (1986).

Even allowing for $50 \%$ thinning due to compaction and pressure solution, the accumulation rates are still very low. However, deeper water carbonates of the 
Vincennes Basin (>150 $\mathrm{m}$ thick) probably were largely derived from the platform. But given that the basinal carbonates from the Vincennes Basin were probably only about 50 $\mathrm{km}$ wide (Milner et al., 1975) this would only increase platform production by about $25 \%$ given the $150 \mathrm{~km}$ conservative width of the Wabash Platform to the Jessamine Dome. Therefore corrected accumulation rates due to the sum of these sources would only increase them to 0.4 to $1.2 \mathrm{~cm} / \mathrm{k} . \mathrm{y}$. Such accumulation rates are about an order of magnitude lower than the maximum rates in the Appalachian and Michigan Basins. Healthy modern carbonate platforms (rates of 100 to $400 \mathrm{~cm} / \mathrm{k}$.y. on reefs and $<10$ cm/k.y. in the lagoon; Schlager, 2003; 2005), have rates two to three orders of magnitude higher than the accumulation rates of the Silurian Wabash Platform.

\section{Tectonic Controls}

Tectonics had a major influence on Silurian deposition because the Late Ordovician arc that accreted onto Laurentia effectively formed an elongate barrier separating the Wabash Platform from the ocean to the east (Fig. 3A; Scotese and McKerrow, 1990). This barrier was enlarged during later Silurian, Baltica-Laurentia collision (Fig. 3B). Consequently, much circulation of open marine water onto the Wabash Platform probably was via the Vincennes Basin, although there could have been influx via breaches in the barrier.

Subsidence rates $(\leq 0.1 \mathrm{~cm} / \mathrm{k} . \mathrm{y}$.) of the Silurian Wabash Platform were extremely low, as were the accumulation rates (Heidlauf et al., 1986). Variation in the extremely low rates of subsidence of the platform is important because sedimentation rates were similarly low. Although, unconformities occur in the Early Silurian succession, later sequences appear conformable, and many did not shallow to sea level, which is 
compatible with the extremely slow sedimentation rates, that were insufficient to overcome even the very low subsidence rates, and decreasing magnitude of sea level changes.

Although during the Silurian, the Wabash Platform was tectonically quiescent, there were some tectonic influences. The Cherokee or Taconic Unconformity from the latest Ordovician to the earliest Silurian (Rhuddanian and Aeronian) is only partly due to the major sea level drop associated with the Hirnantian glaciation. This unconformity is angular within the Appalachian Basin, suggesting a tectonic-influence associated with isostatic rebound during the waning Taconic orogeny, which led to sweeping progradation of siliciclastics into the Appalachian Basin (Dorsch et al., 1994; Ettensohn and Brett, 1998; Faill, 1997a, 1997b; Goodman and Brett, 1994). Onset of the so-called Salinic disturbances associated with collision of Baltica-Laurentia, may be evident in the latest Llandovery (late-Telychian) with renewed uplift of the earlier, Taconic peripheral bulges (Cincinnati and Findlay Arches; Goodman and Brett, 1994). This created an unconformity in the eastern part of the Wabash Platform. A slightly younger phase of relative uplift in the Appalachian Basin in the early Wenlock (Sheinwoodian), is not manifested in the study area (Ettensohn, 1994; Ettensohn and Brett, 1998; Goodman and Brett, 1994).

Middle to Late Silurian flexuring and downwarping of the Wabash Platform to the north and west may have led to thicker deposits in the latest Silurian compared with the Early Silurian, assuming that the present thicknesses have not been drastically affected by post-Silurian-pre-Middle Devonian erosion. By contrast, the Vincennes Basin underwent greatest (but still low) subsidence in the Early Silurian, then slowing from the Middle 
Silurian into the Early Devonian (Heidlauf et al., 1986). Perhaps subsidence of the platform increased as basin subsidence slowed.

The fine clastic component of the Osgood and Waldron Shales (base WS-3 and 6 may have come from the Appalachians to the east (Patchen et al., 1987). Later Silurian Mississinewa argillaceous carbonates that formed during and following Late Silurian flexuring, could have come from a southerly source (Droste and Shaver, 1977; Droste and Shaver, 1982) different from the source of the coeval Bloomsburg redbeds from the tectonic Appalachian highlands to the east and northeast. Adjacent coastal deserts on uplifted regions such as the Jessamine Dome may have provided fine Mississinewa windblown sediment. This influx of Mississinewa clastics to the Wabash Platform, as well as flexuring of the platform could have been due to continuing accretion of Avalonia (Becker and Droste, 1978; Ettensohn and Brett, 1998). This later Silurian flexuring created accommodation that promoted upbuilding of the Terre Haute Bank with its pinnacle buildups in the Ludlow and Pridoli (Shaver et al., 1978). Silurian reefs also could have grown in more shelfward, inner platform settings in the later Silurian, but these could have been eroded due to emergence prior to Middle Devonian deposition (Droste and Shaver, 1987b). Slowing of subsidence into the latest Silurian favored emergence of the Wabash Platform as global sea levels fell (Heidlauf et al., 1986).

\section{Climatic Influences}

\section{Winds and Sources of Marine Waters}

The Wabash Platform was located in the Silurian southern tropics (20 to $25^{\circ} \mathrm{S}$, and rotated approximately $45^{\circ}$ clockwise from its present day position; Mikulic, 1990; Scotese et al., 1979; Scotese and Mckerrow, 1990; Witzke, 1990) (Mikulic, 1990; 
Scotese et al., 1979; Scotese and McKerrow, 1990; Witzke, 1990), suggesting that it may have been located in the Trade Wind belt with dominantly easterly winds (Brown et al., 1989; Pope and Steffen, 2003). This is borne out by paleoclimate modeling, which shows the Wabash Platform was influenced year-round by prevailing southeasterly winds (Herrmann et al., 2004; Moore et al., 1994).

Given these prevailing south-easterly winds, the Terre Haute Bank bordering the Vincennes basin was a leeward margin, while the Fort Wayne Bank bordering the Michigan Basin would have been a windward margin, albeit with a smaller basinal fetch. However, the individual buildups on the Wabash Platform show a south to north fore-reef to back-reef polarity (present day geography; Shaver et al., 1978), suggesting that they were influenced by waves from the southwest (Silurian paleogeography) traversing the deep Vincennes Basin. These may be related to southwest wind-generated waves associated with winter storms, or perhaps hurricanes, or could be swell waves generated far to the south in the westerly wind belt.

The prevailing southeasterly wind system would have resulted in northwestward drift of surface waters across the platform, that is, from the interior of the platform toward the Vincennes basin margin. If waters were moving across the platform via openings in the Appalachian tectonic highlands then they would have to come from at least $500 \mathrm{~km}$ away, and as much as $1500 \mathrm{~km}$ away in an upwind direction if the seawater passages were in Maritime Canada (Milner et al., 1975; Scotese and McKerrow, 1990). If sufficiently strong, the southeasterly winds also would have tended to impede tidal flow onto the platform from the Vincennes Basin. All of these factors suggest that the waters of the Wabash Platform had long residence times, which would have tended to 
deplete them of nutrients and calcium and bi-carbonate ions, and result in extremely low sedimentation rates on the platform (Atkinson et al., 1981).

\section{$\underline{\text { Climate and Quasi-estuarine and Anti-estuarine Circulation }}$}

Climate also influenced water circulation and development of low oxygen bottom waters (Fig. 12). Given the westward current drift and cooler, humid Early Silurian climate, circulation initially was quasi-estuarine (Fig., 12A; Witzke, 1987) with inshore waters slightly less saline and less dense than inflowing waters from the Vincennes Basin, which would have had to move as an upwelling underflow beneath the basinward directed surface water drift. This would have favored stratification and low oxygen content in bottom waters, where the Wabash platform lay below the mixed layer. Nutrients from Appalachian rivers also might have provided nutrients to coastal areas of the Appalachian Basin, which might have promoted increased productivity by phytoplankton in nearshore areas, and further depleted oxygen in the waters prior to their migration out onto the Wabash Platform.

In the predominantly arid later Silurian with evaporation far in excess of precipitation, circulation was anti-estuarine (Fig., 12B; Witzke, 1987) with surface waters on the inner platform having slightly elevated salinities, which would have caused them to sink and move seaward. The slightly more saline surface waters generated on the inner platform also likely were ponded in deep lagoonal areas behind the sill provided by the later Silurian Terre Haute Bank, if these areas lay below the mixed layer. As a result, these deeper lagoonal areas also tended to develop low oxygen conditions during high sea levels even under anti-estuarine circulation. Thus in spite of the climate change, the evolving platform continued to promote periodically low oxygen conditions of bottom 
waters during highstands of sea level.

As a result of anti-estuarine circulation, incoming waters from the Vincennes Basin would have had to move onto the platform as a surface layer against the westward drift, impeding movement far onto the platform, and increasing residence time (Witzke, 1987). Bringing the marine waters from the east via gaps in the Appalachian tectonic highlands as part of the westerly drift would not greatly shorten residence times, as these would have had to move such long distances, as well as pass through the Fort Wayne Bank, which would have depleted them of nutrients and dissolved calcium ions (c.f. Smith and Atkinson, 1984). Evaporation of platform waters would have resulted in a gradual continued flux of sea water onto the platform to replace that lost to evaporation, which would have tended to increase nutrient levels. However these would have been rapidly depleted of nutrients as the waters passed over the banks, sites of relatively high productivity compared to the sediment starved, nutrient-poor platform interior, as in Shark Bay today (Smith and Atkinson, 1984).

\section{Glacial Versus Non-glacial Climate Modes}

There is considerable evidence for cooler Early Silurian and later Silurian warming. The major but short-lived, Late Ordovician Hirnantian glaciation, lasting approximately $<1-$ m.y., and the three glaciations in the Llandovery and early Wenlock (early Aeronian, latest Aeronian - early Telychian and latest Telychian - earliest Sheinwoodian) (Caputo, 1998; Caputo and Crowell, 1985; Crowell, 1983; Grahn and Caputo, 1992; Harris et al., 1998; Husseini, 1990; Powell et al., 1994), indicate several short phases of global icehouse conditions during the Late Ordovician (Caradoc) and into the Early Silurian (earliest Wenlock; Brenchley et al., 1994; Caputo, 1998; Kaljo et al., 
2003). In addition, this Early Silurian climate was cooler and wetter than later, manifested by clastic-dominated successions in the Appalachian Basin from the Llandovery until the Wenlock, and evidence of fine siliciclastic influx near bases of some of the Wabash Early to Middle Silurian sequences (Brett et al., 1990; Frakes et al., 1992).

Warming began in the Middle Silurian (Bickert et al., 1997; Frakes et al., 1992), and was accompanied by drying of the climate. Continued aridification promoted deposition of major cyclic evaporites in the adjoining Michigan and Appalachian Basins in the Late Silurian (Droste and Shaver, 1977; Mesolella et al., 1976; Shaver et al., 1978; Witzke, 1990). The dry climate also may have increased influx of windblown fine clastics from adjacent coastal deserts, contributing fine clastics to argillaceous silty carbonates in the Mississinewa Shale Member (Droste and Shaver, 1977; Witzke, 1990). Slightly wetter conditions prevailed in the area during the latest Silurian, with deposition of the evaporite-free, Lower Helderburg carbonates and clastics in the Appalachian Basin (Dorobek and Read, 1986; Smosna, 1988; Smosna et al., 1977).

\section{Controls on Thickness of Sequences}

The relative thinness of the Wabash-Silurian sequences resulted from a combination of low sedimentation rate $(0.3$ to $0.8 \mathrm{~cm} / \mathrm{k} . \mathrm{y})$ coupled with low accommodation rate $(<1 \mathrm{~cm} / \mathrm{k}$.y.). The low sedimentation rates prevented upward shallowing of most sequences to sea level except over buildups, or where glacio-eustatic sea level falls were significant, as in the Early Silurian. Consequently, the facies within sequences are subtidal, and there is little evidence for peritidal deposition in the study area. Sequences WS-1 to 3 were only able to shallow to become non-depositional or undergo erosion, because glacio-eustatic sea level falls were significant (Becker, 1974; 
Nicoll and Rexroad, 1968; Rexroad, 1980). Even though sequences WS-4 to 6 remained subtidal, they were unable to develop significant thicknesses due to low sedimentation rates and low accommodation, and relatively small sea level fluctuations after disappearance of Gondwanan ice sheets following the Early Silurian glaciation.

The thickness of sequence WS-7 and 8 downdip reflect higher sedimentation rates due to buildup growth, and if there has not been extensive erosion of the updip platform, slightly higher accommodation rates due to flexuring peripheral to the Jessamine Dome (Shaver et al., 1978). By the end of the Silurian, there was approximately $40 \mathrm{~m}$ of relief between the tops of buildups and the sediment-starved inner platform (Droste and Shaver, 1980), indicating unfilled accommodation and low accumulation rates away from the buildups.

\section{Controls on Eustacy and Sequence Boundary Development}

A eustatic signal would be expected on the Wabash Platform, given the very slow subsidence rates on the platform (Heidlauf et al., 1986), implying that tectonics had less an influence on sequence development (Fig. 13). Glacio-eustacy is a likely cause of the Early Silurian sea level cycles, given the evidence for Gondwanan glaciations (Brenchley et al., 1994; Caputo, 1998; Caputo and Crowell, 1985; Crowell, 1999; Grahn and Caputo, 1992; Harris et al., 1998; Kaljo et al., 2003). Comparison of the Silurian Wabash Platform sea-level cycles with inferred global cycle and local sea level cycle curves elsewhere indicates a significant eustatic component (Figs. 4, 11).

The end Ordovician to Early Silurian (early Llandovery) unconformity can be correlated to the Hirnantian Glaciation (Fig. 4). At this time, a 50-100 m of sea level drop exposed the platform to erosion and non-deposition (Fig. 13A; Brenchley et al., 
1994; Johnson et al., 1998b; Powell et al., 1994). Relief on this unconformity ranges from $10-70 \mathrm{~m}$ in Laurentia, and up to $275 \mathrm{~m}$ of relief within paleovalleys in Saudi Arabia on Gondwana (Johnson et al., 1998a). The Hirnantian sea level fall may have formed lowstand, thin oolite units downdip in the Illinois Basin (Shaver, 1984).

Sequence WS-1 (Rhuddanian to early Aeronian) correlates well with sea level cycles from elsewhere and cycles 1 of the global composite sea level curve (Johnson, 1996). It appears to correlate also with the Great Basin sea level curve, but which contains a larger and a smaller sea level cycle superimposed (Harris and Sheehan, 1998). This post-Hirnantian 50 to $100 \mathrm{~m}$ sea level rise flooded the emergent platform to form sequence WS-1 with grainstones updip (water depth $<35 \mathrm{~m}$ ) and wackestones grading into deeper water carbonate mudstones downdip (water depth $>60 \mathrm{~m}$ ). During sequence WS-1 deposition, the inner shelf must have stood relatively high, resulting in high energy, shallow water conditions updip and widespread glauconitic crinoidal grainstones, attesting to slow sedimentation rates and influx of clay. Regional slopes on the ramp caused the downdip western and northern parts of the ramp being flooded to significant water depths.

The major hiatus between sequence WS-1 and 2 in the mid to upper Aeronian and early Telychian, is represented on the global sea level curve and in the rapidly subsiding Great Basin by two sea level cycles (Fig. 11; cycles 2 and 3 of Johnson, 1996; Harris and Sheehan, 1998). The early Aeronian glaciation (Glaciation I, Fig. 4) and the latest Aeronian - early Telychian glaciation (Glaciation II, Fig. 4) span the time interval of the missing sequences and lie in the major break between sequences WS-1 and 2. Substantial erosion with up to $60 \mathrm{~m}$ of relief during the lowstand occurred in Wales and 
China, but the widely spaced core data used in this study was not able to detect any significant down-cutting. However, there is up to $53 \mathrm{~m}$ of erosional relief developed in Illinois and Wisconsin with widespread karstic weathering at this time (Kluessendorf and Mikulic, 1996; Mikulic and Kluessendorf, 2001), and up to $50 \mathrm{~m}$ of local high relief erosional surfaces have been recorded on Anticosti Island, Quebec (Desrochers, 2006). However, there is no obvious macroscopic evidence for subaerial exposure and diagenesis on the underlying sequence WS-1 in the cores. This unconformity is coeval with the lowstand between Johnson's sea level cycles 3 and 4, and most likely resulted from Glaciation II (Fig. 4; Desrochers, 2006). It is possible that regional uplift on the Wabash Platform caused the omission of global sea level cycles 2 and 3 from the Wabash Platform, which probably was at too high an elevation to be flooded.

Sequence WS-2 does not correlate with the Johnson composite global curve or other curves. Sequence WS-2 predates Ettensohn's $1^{\text {st }}$ Salinic Tectophase, (Boucot, 1962; Ettensohn, 1994) tending to rule out a tectonic cause. However, deposition of sequence WS-2 was initiated by deglaciation of Glaciation II (Fig. 4) on Gondwana.

The latest Telychian - earliest Sheinwoodian Glaciation (Glaciation III, Fig. 4) possibly correlates with the WS-3 lowstand. Published data suggests that this relative sea level lowstand is an unconformity along the Cincinnati and Findlay Arches, which could have resulted from isostatic far-field uplift in response to subsidence and deposition of thick siliciclastics in the Appalachian Basin (Goodman and Brett, 1994). More likely Glaciation III triggered sea level fall which exposed the top of sequence WS-2 updip, evidence for which can been seen in mud-infilled cavities within grainstones.

Deglaciation initiated deposition of sequence WS-3, with the basal Osgood Shale. 
Sequence WS-3 does not correlate with the inferred timing of sea level cycle 4 of the global composite curve of Johnson (1996). However it does correlate with sea level cycle 4 on the individual curves from Laurentia, Gondwana (Talent et al., 2003), Baltica (Johnson et al., 1991), Bohemica (Kriz, 1991) and China (Johnson and McKerrow, 1991) and cycle sea level cycle 6 of Laurentia of Harris et al. (1998).

Sequence WS-4 correlates with the second of two sea level cycles making up cycle 5 of Johnsons' composite sea level curve and the cycle is evident on most local curves (Fig. 11; Johnson, 1996). Sequence WS-5 correlates with an event in Gondwana and Laurentia, but does not correlate well with global composite curve. Sequence WS-6 correlates well with the sea level cycle 6 of the global composite curve of Johnson (1996). On Gondwana, three events are evident in cycle 6, which are also evident in Indiana. Sequence WS-7 and 8 correlate well with sea level cycles 7 and 8 respectively of the Johnson global composite curve.

The mapped conformable boundaries of sequences WS-4 through 8 on the platform like are transgressive surfaces on the shallowest water (but still relatively deep) facies near the top of the sequences, rather than correlative conformities, which probably are cryptic surfaces that would lie slightly lower in the section. They probably reflect relatively small sea level falls (Fig. 13B), given the absence of glacial deposits on Gondwana. The sea level drops likely were insufficient to expose the platform given its $>35 \mathrm{~m}$ water depths, except outside the study area over shallow highs or where peritidal facies locally developed on some buildups of the Terre Haute and Fort Wayne Banks (Tollefson, 1978). Locally, at the base of sequence WS-8, there is up to $30 \mathrm{~m}$ of erosional karstic relief is developed in Ohio over the Cincinnati Arch (Kahle, 1988). The 
causes of the Middle and Late Silurian sea level falls are not clear, given the paucity of evidence of glaciations on Gondwana at this time (Grahn and Caputo, 1992). Perhaps deposits of minor glaciations were eroded by later Devonian-Carboniferous glaciations, or the glaciations were confined to mountain or piedmont glaciers, which would have little chance of preservation. Such small glaciations likely would cause smaller sea level fluctuations than those of the Early Silurian. However, there is little macroscopic evidence in the cores for exposure even in sequences WS-1 through 3, even though biostratigraphic gaps mark the boundaries. Thus short-term exposure cannot be completely ruled out for sequences WS-4 through 8 .

The end Silurian to lower Devonian unconformity following deposition of sequence WS-8 on the Wabash Platform resulted from a sea level drop that is a major global event (Johnson, 1996; Sloss, 1988), during which there was some karsting and beveling of the more slowly subsiding Silurian carbonates updip.

\section{Controls on Lowstand Systems Tract Development}

Wackestone and lesser grainstone facies of the lowstand systems tracts formed on the deep ramp in front of the Terre Haute Bank during lowered sea level stages. The lowstand grainstones in Well 7 lie in a more basinward position than Well 6, which lacks such facies, suggesting Well 7 grainstones formed over a basinal high. The conformable, correlative conformities beneath the lowstand deposits on the deep ramp, and the paucity of lowstand clastics, suggest that sea level falls did not expose the deep ramp, and that any source of siliciclastics was far distant. It is probable that some wacke-packstone caps (water depths 20 to $35 \mathrm{~m}$ ) beneath conformable surfaces mapped as sequence boundaries are in fact lowstand deposits, and that the conformable boundary is the transgressive 
surface (Van Wagoner et al., 1988).

Controls on Transgressive Systems Tracts Development

Local absence of significant transgressive systems tracts in a few sequences could be the result of localized very low sedimentation rates (Allison and Wright, 2005;

Demicco and Hardie, 2002), in which effectively there was no sedimentation on the starved platform interior. It is also likely that sea level rise relative to sedimentation rate was so rapid that the platform underwent local incipient drowning. This could be due to an extended lag time or lag depth during which little sediment was being produced during transgressive deepening (Goldhammer et al., 1990; Koerschner and Read, 1989).

The upward change from poorly fossiliferous to non-fossiliferous wackestones to mudstones in transgressive systems tracts indicates a change from oxygenated to low oxygen conditions in bottom waters. In the humid Early Silurian, large rivers flowing into the northern Appalachian Basin, would have generated a quasi-estuarine circulation with low salinity surface water providing a lid on the platform waters, resulting in low oxygen conditions below the pycnocline once waters became deep enough (Bickert et al., 1997; Cramer et al., 2006; Witzke, 1987). This may have played a role in the development of transgressive systems tracts in sequences WS-1 and 2.

However, as the climate became more arid and the circulation became antiestuarine (Witzke, 1987), the salinity stratification would have been inverted with evaporative concentrated surface waters sinking and ponding into any silled, deeper areas of the platform, resulting in low oxygen conditions and deposition of carbonate mudstones, in a similar manner to that described by Cramer et al.(2006) and Brett (1999) for the Appalachian Basin. Where the ramp lacked any sill, these low $\mathrm{O}_{2}$, low nutrient 
bottom waters would have flowed downslope into the Vincennes Basin.

Most sequences have well developed transgressive systems tracts, but simple upward deepening trends are complicated by parasequence development. Argillaceous carbonates make up transgressive systems tracts in the Osgood, Waldron and Mississinewa "shales". These fine siliciclastics likely were not from transgressive reworking of clastics that moved out onto the platform during lowered sea levels, nor are they simply due to backstepping of nearshore siliciclastic-prone lagoonal facies because they locally overlie clastic-free wackestone of the early transgressive systems tract (AlTawil et al., 2003). Most argillaceous carbonates, such as the Waldron Shale, show an upward increase in fine siliciclastics in the transgressive systems tract which could reflect initial cooler, drier climates due to lowered sea levels, and slightly increasing seasonal rainfall as flooding continued, favoring clastic influx. Climates then became drier as the globe warmed, and sea level peaked, shutting off the clastic input. The upward increase in clastics also was due to declining carbonate deposition due to increasing water depth, decreasing light, and stratification of the water column which led to decreased oxygen on the sea floor (Feldman, 1989). The sea floor initially lay in the photic zone between fair weather and storm-wave base. As transgressive water depths increased, a stressed environment below storm wave base developed with high turbidity and decreased oxygen concentration (Feldman, 1989). Clastic-free wackestone facies that occur downdip of units such as the Osgood "Shale" reflect decreased influx of fine clastics onto the deeper offshore part of the inner ramp.

The upward deepening of the transgressive tracts and backstepping of clastic-free wackestone units in argillaceous carbonate-prone parasequences (as in sequence WS-7) 
reflect sedimentation rates lower than accommodation rates during transgression. Given the low tectonic subsidence $<1 \mathrm{~cm} / \mathrm{k} . \mathrm{y}$. (Heidlauf et al., 1986), this short term accommodation generated by subsidence would have been less than $10 \mathrm{~m}$ for a million year sea level rise, thus most accommodation must have been generated by sea level rise that outpaced sediment upbuilding. Although it seems likely that humid conditions may have caused influx of water-borne fine siliciclastics, windblown fines might have contributed siliciclastics as the long-term climate became more arid (Droste and Shaver, 1977). The clastic sediments were not detrimental to reef growth on the Wabash Platform (Shaver et al., 1978), as the major buildups developed during times of significant terrigenous clastic influx (e.g. Mississinewa "Shale"), perhaps because the terrigenous fines were carried by bottom-hugging warm saline bottom waters once the turbid influxing waters had become mixed with platform waters.

Carbonate-prone transgressive systems tracts are usually thinner $(<2 \mathrm{~m}$ thick $)$ than transgressive systems tracts with argillaceous carbonates. Influx of clastics might have added to the overall low sedimentation rates. How climate might have limited influx of clastics to form carbonate-prone transgressive systems tracts is not clear, because the carbonate-prone transgressive systems tracts occur throughout the section. Perhaps sea level was sufficiently high so that there were no nearby coastal deserts and little influx of clastics during more arid phases, or the Cincinnati Arch and subtle highs on the ramp may have been sufficient to bar water-borne siliciclastic influx from the Appalachians (Zuppann, 1988).

\section{Controls on Highstand Systems Tract Development}

The Wabash Platform highstand systems tracts developed during near stable to 
gradually falling sea levels. The transition from poorly fossiliferous mudstones culminating in wackestone or wacke-packstone is due to shallowing from below the pycnocline to above the pycnocline. The low subsidence rates provided little accommodation (less than $10 \mathrm{~m}$ during the transgression), so that the highstand systems tracts tended to fill the accommodation left from the transgressive phase, which decreased as eustatic sea level fell and hydro-isostatic rebound occurred, offsetting the small amount of long term subsidence during the fall.

Given the thinness of most of the sequences (few meters to $10 \mathrm{~m}$ ), only part of the relative sea level fall could have come from upbuilding, except over buildups, where sediment rates were relatively high. In the Early Silurian where sea level changes were perhaps tens of meters, decreased accommodation due to sea level fall was substantial, culminating in erosion. However, the inferred smaller sea level changes in the later Silurian suggests that shallowing by sediment-upbuilding could have been important, especially on and adjacent to the buildups which had relatively high sedimentation rates. Flexuring of the Wabash Platform during deposition of sequences WS-7 and 8 could have increased the accommodation downdip, thus yielding the thick highstand buildups (Shaver et al., 1978).

Except for sequence WS-1, where the inner platform stayed above fair-weather wave base and local areas of sequences WS-4 and 5, most sequences shallowed only to mud-prone wacke-packstone facies. This suggests that late highstand water depths remained below fair-weather wave base (water depths of perhaps 10 to $20 \mathrm{~m}$ ), and/or tide and wave energy on the muddy inner platform was insufficient to winnow the fines. These subtidal late highstand water depths in the Middle to Late Silurian are borne out by 
open marine biotas and lack of evidence for emergence to tidal or subaerial levels (sequences WS-4 to 8). Reported progradational geometries and toplap relations on buildups indicate that sedimentation rates were significantly greater than accommodation rates during highstand deposition of prograding grainy flank facies on the buildups. Most buildups were too small to generate tidal flat facies because sediment was continually swept off the buildups by waves and currents, preventing shallowing to tidal levels, and promoting progradation of flank facies (Textoris and Carozzi, 1964). The succession only became regionally exposed during the end Silurian global sea-level fall and the ensuing low sea levels of the Early Devonian (Sloss, 1988).

\section{Controls on Parasequence Development}

Parasequences are relatively scarce in the Silurian of the Wabash Platform due to very low accommodation. Only 1 to 2 parasequences occur in each Early Silurian sequences. By contrast, in the high accommodation settings of the Great Basin, U.S.A. there are 7 to 20 parasequences per sequence (Harris and Sheehan, 1998) indicating fourth order cycles (>100 k.y. each). This is compatible with "transitional" eustacy associated with moderate ice-sheets (Read et al., 1995). Sequences WS-4 through 6 on the Wabash Platform have (up to 7 parasequences per sequence) again indicating fourth order $>100$ k.y. cycles. In buildups in Wabash Platform sequences WS-7 and 8, 3 to 11 parasequences are developed per sequence, again suggesting fourth order parasequences. However by contrast, in the high accommodation setting of the Appalachians, Pridoli cycles appear to be precessional $(<20$ k.y.) and dominated by peritidal facies in the Tonoloway Formation (Bell and Smosna, 1999; Smosna et al., 1977) and in the latest Silurian and Early Devonian of the Helderberg Group (Anderson and Goodwin, 1990; 
Dorobek, 1987). This indicates that the climate was greenhouse with little ice.

\section{Controls on Low Sedimentation Rates}

The low accumulation rates on the Silurian Wabash Platform (from 0.3 to 0.8 $\mathrm{cm} / \mathrm{k} . \mathrm{y}$.) are one to two orders of magnitude lower than modern carbonate platforms. These rates are low, even taking into account the well-documented decrease in sedimentation rates with increasing time span (Sadler, 1981). The estimated duration of the disconformities on the platform, and the relative scarcity of hardgrounds rules these out as a major cause of the apparent low rates. Some modern inner platform settings have relatively low sedimentation rates (Belize lagoons; 6 to $60 \mathrm{~cm} / \mathrm{k} . y$.; lagoonal Florida Bay; 1 to $40 \mathrm{~cm} / \mathrm{k} . \mathrm{y}$.) although these are at least 4 times higher than the Silurian (Bosence and Waltham, 1990; Gischler, 2003; Yang et al., 2004). The very low sedimentation rates on the Wabash Platform and Vincennes Basin were generally too low to fill to sea level even with the extremely low accommodation rates, which resulted in dominantly subtidal sediments (Droste and Shaver, 1987a). As a result of the unfilled accommodation, there were few subaerial exposure events, except in the glacially influenced Llandovery when sea level falls were greatest.

For the Bahamas Platform, Demicco and Hardie (2002) calculated production rates of less than $60 \mathrm{~cm} / \mathrm{k} . \mathrm{y}$. some $20 \mathrm{~km}$ from the platform margin, that approached zero production in the innermost area. This decreased production was attributed to long residence times of waters and shallow water depths between 5 to $10 \mathrm{~m}$ which is much shallower than the water depths ( $\sim 15$ to $35 \mathrm{~m})$ estimated for the interior Wabash Platform (Droste and Shaver, 1987a). On carbonate platforms wider than $100 \mathrm{~km}$ and water depths less than a few meters, high rates of carbonate production would be difficult to maintain, 
resulting in the platform interior being a carbonate sink, rather than a carbonate source and sink. Modeling reinforces this idea that productivity on platforms decreases both with decreasing water depth and increasing distance from the platform margin (Bosence and Waltham, 1990).

Very low sedimentation rates in large platform interiors also could be due to stratification of the water column (Allison and Wright, 2005). Large epi-continental platforms are sufficiently distant from the open ocean, so that tides might be very low, in the absence of tide-amplifying basin geometries. This would promote stratification due to lack of tide/wave mixing of the water column. Stratification of the water mass and quasi-estuarine circulation in the Early Silurian humid cool phase likely was due to influx of fresh water to form slightly decreased salinity surface waters on the inner ramp. With the influx of a surface "lid" of turbid freshwater onto the platform, light penetration to the bottom decreased (shutting down photosynthesis) the water mass stratified, low bottom oxygen levels developed creating highly stressed environment below storm wave base, decreasing biologic production and calcification, accompanied by deposition of argillaceous, poorly fossiliferous carbonates (Feldman, 1989). The fines in the muddy platform sediments likely were easily re-suspended by waves (storms) which also would have decreased light penetration, decreasing production. This low light is supported by the relative scarcity of skeletal algae and calcified microbes in the Silurian platform succession.

Stratification during the more arid, later Silurian probably was promoted by the raised rim barrier bank complex rimming the platform, which acted as a discontinuous sill to out-flowing marine, slightly more saline bottom waters (anti-estuarine circulation). 
This would have formed a microtidal or atidal inner ramp, on which salinities increased slightly with depth, and the outflow of warm, saline bottom waters was impeded (but not stopped) by the discontinuous rim, and its intervening broad passages. Where the deep lagoon seafloor behind the banks lay below the depth of the mixing, a stagnant layer formed (Tollefson, 1978) and the resulting salinity stratification was accompanied by decreased oxygen levels, suppressing productivity.

Hypersalinity (as opposed to density stratification due to slightly increased salinities of bottom waters) cannot be called upon for decreased sedimentation rates for much of the later Silurian Wabash Platform because most of shallower water wackestones have relatively open-marine benthos (Tollefson, 1978). Michigan Basin evaporites mark the edges of regressing and transgressing brines acting on seafloor, indicating that brines did not extend onto the Wabash Platform (Droste and Shaver, 1977).

\section{Isotopic Evidence for Eustatic Control on Sequences}

Stable isotope excursions documented by various workers for Late Ordovician through basal Devonian indicates a global eustatic cause of supersequence boundaries, and for at least three of the Silurian sequences (Cramer and Saltzman, 2005; 2007; Jeppsson et al., 1990; Saltzman, 2001; 2005; Witzke, 1987).

The Ordovician-Silurian supersequence boundary is accompanied by major positive global excursions in carbon and oxygen, associated with the Late Ordovician Hirnantian glaciation (Azmy et al., 1998; Brenchley et al., 1994; Holmden et al., 1998), the oxygen isotope excursion marks ice buildup on Gondwana, and the positive carbon excursions are attributed to increased burial of light carbon coupled with influx of heavy 
carbon from exposed carbonate terrains (Saltzman, 2002). The end Silurian supersequence boundary also has a marked positive excursion globally associated with shallowing, with significant exposure on the shallow platforms indicating a eustatic (but not necessarily glacio-eustatic) origin. The Silurian-Devonian carbon excursion is again attributed to increased carbon burial within the epeiric seas and influx of riverine heavy carbon (Saltzman, 2002).

In contrast, the three major positive carbon isotope excursions within are associated with highstands rather than lowstands. During cold lowstand phases, high latitude cooling generated low sea levels, and cold saline bottom water ventilated the oceans (Cramer and Saltzman, 2007; Jeppsson et al., 1990). During transgression, where conditions were favorable, these nutrient rich waters upwelled onto the continental margins. The cool humid climates on the shelves favored quasi-estuarine circulation during transgression, which provided a "lid" on the platform nutrient rich waters, resulting in low oxygen conditions below the pycnocline initiating the $\delta^{13} \mathrm{C}$ excursion. As climate warmed and became more arid and water depths increased on the platform, became sites of widespread carbonate deposition (late transgression to early highstand; Cramer and Saltzman, 2007. The inner platform areas became a source of warm saline waters undergoing anti-estuarine circulation (evaporation in excess of precipitation); these saline bottom waters flowed off the platforms into the oceans, shifting the source of bottom water production from the high latitudes to middle latitudes (Azmy et al., 1998; Cramer and Saltzman, 2007). Widespread anoxia developed in the deep oceans, resulting in widespread organic carbon burial. This culminated in the major positive $\delta^{13} \mathrm{C}$ excursion, as the source of light carbon in the deep oceans became 
disconnected from the isotopically heavy carbon of the epi-continental waters due to diminished return of the biological pump. As $\mathrm{CO}_{2}$ was drawn down, the climate cooled, sea levels fell, and the oceans started to re-ventilate, releasing light carbon, pushing $\delta^{13} \mathrm{C}$ to low background values as the oceans re-ventilated.

These climatic and associated sea level fluctuations led to the Silurian having more frequent, major $\delta^{13} \mathrm{C}$ excursions than any other period in the Phanerozoic (four excursions of $\delta^{13} \mathrm{C}>+4 \%$ in $\sim 30$ m.y.; Azmy et al., 1998; Bickert et al., 1997; Cramer and Saltzman, 2007; Cramer et al., 2006; Saltzman, 2001; 2005). The biostratigraphy indicates that the major Silurian positive carbon isotope excursions immediately post-date deposition of the major argillaceous carbonate units. Perhaps the "shales" of the Osgood, Waldron and Mississinewa mark major events in the stratigraphy, heralding more extreme swings in climate (Cramer and Saltzman, 2005).

\section{Controls on Development of Bank Complex}

It is tempting to suggest that local sea surface temperature was a major control on the onset and growth of the buildups. This is suggested by major extinction of reefal assemblages in the Late Ordovician Ashgillian glaciation and lowered sea level, and the presence of three glaciations in the Early Silurian and the lack of later Silurian glaciations. During this time, biodiversity of Silurian reefs increased (cf. Copper 2002). Although isotopic data suggests a return to greenhouse sea surface temperatures in the early Llandovery, reef return took considerably longer (Azmy, 1999 in Copper, 2002). The Silurian reef belts expanded globally into the Middle Silurian Wenlock. In terms of Silurian paleogeography, the Wabash Platform lay on the downstream (cooler) end of a major south- to southwest-directed warm current-system flowing from the tropics along 
eastern North America. This warm current would have favored reef development in its warmer upstream part, with the downstream end favoring reef growth only during times of major global warmth. The ramp was relatively deep with cooler basin derived bottom waters throughout its extent in the Early Silurian. However as the Silurian climate warmed, and deeper water mud banks (adapted to cool waters) built up along the margin into shallow warmer waters, they were succeeded by more "reefy" assemblages, although significant framebuilt structures are relatively rare. Silurian stromatoporoids and corals probably had relatively rapid growth rates and probably were zooxanthelate.

Stromatoporoids likely were aragonite in contrast to the calcite corals (Copper, 2002).

The relative synchronaeity of onset of evaporite deposition in the Michigan and Appalachian Basins with buildup development along the Wabash Platform margins suggests that they are related. It seems likely that salinity would have increased across the arid Wabash Platform into the Michigan and Appalachian Basins. This "antiestuarine circulation system would have tended to increase nutrient concentrations in the platform waters as the climate aridified, in a similar manner to that occurring on the modern banks of Shark Bay where waters generally are nutrient poor (Davies, 1970; Logan and Cebulski, 1970; Smith and Atkinson, 1984). The large excess of evaporation over precipitation tends to increase nutrients in the water mass, but these are quickly utilized by the bank biotas of autotrophs and heterotrophs, so that phosphorous levels are reduced to near zero above salinities of $48 \%$, the limit of seagrass bank growth in Shark Bay (Smith and Atkinson, 1984). The maximum carbonate bank production of 100 $\mathrm{cm} / \mathrm{k}$.y. occurs in the shallow photic zone (typically $<10 \mathrm{~m}$ water depth) on tops of shallow fringing and barrier banks within the metahaline water mass (40 to $48 \%$ ), with 
diverse, bank building biotas associated with sea grasses. Growth of sea grasses is reduced in the oceanic and hypersaline parts of Shark Bay, and banks are absent. It seems unlikely that Paleozoic communities would not have had macroalgae or some other soft-bodied assemblage in the niche occupied by modern grasses, and thus onset of negative estuarine circulation might have triggered bank-complexes along the Wabash Platform margins, given that this epi-continental platform was so nutrient-poor because of limited exchange with the distant ocean.

However, as the banks grew, they further depressed sedimentation rates in the platform interior as in Florida Bay (Wanless et al., 1995) and Shark Bay (Hagan and Logan, 1974; Smith and Atkinson, 1984). This could have shut down sedimentation on the inner part of the Wabash Platform, so that only a relatively thin succession developed here. This would have been subsequently stripped during the Early Devonian emergence.

\section{Early Dolomitization of the Platform}

Although early dolomitization was not part of this study, there is an increase in fabric-preserving fine dolomite both upsection and downdip from the inner- to the midramp. This downdip increase in dolomitization is opposite to the trend commonly seen on early reflux dolomitized platforms which commonly have widespread tidal flat facies updip. The subtidal ramp carbonates bordering the Vincennes Basin were determined, via geochemical studies including ${ }^{87} \mathrm{Sr} /{ }^{86} \mathrm{Sr}$ isotopes, to have been dolomitized during very early burial by seawater or modified seawater rather than by burial brines from the Vincennes Basin (Kruger and Simo, 1994). In the presence of dolomitizing fluids, the muddy carbonates of the Wabash Platform would have been highly susceptible to dolomitization given their fine grain size and large surface area (Kruger and Simo, 1994). 
There likely was a climatic influence given that the Early Silurian was relatively humid, whereas the later Silurian was arid and probably generated more dolomitizing waters. During humid phases, updip regions along the Cincinnati Arch with brackish lenses may have acted as a hydrologic pump drawing in seawater into the platform from the Vincennes Basin as proposed for the Bahama Platform (Kruger and Simo, 1994; Vahrenkamp et al., 1991).

Hypersaline brines (but below gypsum and anhydrite saturation) may have been produced during arid climate, synchronous with evaporite deposition in the Michigan Basins (Droste and Shaver, 1977). A spatial control on dolomitization could have arisen as sea level periodically fell below the level of the elevated rim, and lagoonal waters became more saline and denser. During arid phases, these saline waters likely underwent reflux, dolomitizing the downdip subjacent parts of the ramp, while updip regions, especially along the Cincinnati Arch, were not hypersaline, due either to fresh water dilution (in the Early Silurian) or perhaps exposure over the Jessamine Dome.

\section{SIGNIFICANCE AND CONCLUSIONS}

The Wabash Platform provides an example of sequence development on an accommodation-limited, sediment-starved carbonate ramp in an epeiric setting on Laurentia. Low sedimentation rates (inner ramp, $0.3 \mathrm{~cm} / \mathrm{k}$.y. mid-ramp buildups 0.8 $\mathrm{cm} / \mathrm{k} . \mathrm{y}$.) were one to two orders of magnitude lower than modern platform rates. In spite of the extremely low accommodation rates $(<1 \mathrm{~cm} / \mathrm{k} . \mathrm{y}$.), the sea floor tended to remain deeply submerged except during Early Silurian glacio-eustatic lowstands, and over later Silurian buildups. In the later Silurian, increased mid-ramp sedimentation rates generated raised, discontinuous barrier banks bordering the basins, although the outer ramp still 
maintained its low gradient and the inner ramp remained sediment-starved. This resulted in differential relief in which the buildup complex was some $40 \mathrm{~m}$ higher than the inner ramp surface (Droste and Shaver, 1980).

Such astonishingly low sedimentation rates on the platform could have been due to the great distance of this epeiric sea ramp from a source of open marine waters, its leeward margin position with regard to prevailing easterlies, long residence times of waters, persistent deeper subtidal water depths, the large size of the platform $(200,000 \mathrm{sq}$ $\mathrm{km}$ ), and stratification in the water column, all of which limited or even shut down the carbonate factory (Allison and Wright, 2005; Bosence and Waltham, 1990; Demicco and Hardie, 2002).

During cooler, humid phases (Early Silurian, and some later Silurian transgressive systems tracts), circulation was quasi-estuarine, in which less saline surface waters formed a "lid" promoting low $\mathrm{O}_{2}$ conditions below the pycnocline. During warmer, arid phases (later Silurian highstands), anti-estuarine circulation with dense, saline inner platform waters sinking and moving seaward dominated, but because of the growth of buildups along the margin, still generated low $\mathrm{O}_{2}$ conditions below the pycnocline in deep lagoons. These switches in climate and circulation have been implicated in the reported global $\delta^{13} \mathrm{C}$ excursions in the Silurian in moving the site of saline bottom water formation between high latitude and mid-latitude areas (Cramer and Saltzman, 2007).

In the Early Silurian, significant glacio-eustatic sea level changes driven by waxing and waning of Gondwana ice sheets resulted in biostratigraphically determined, disconformable sequence boundaries. In contrast, the later Silurian may have had smaller sea level changes, thus sequences are more conformable. These later Silurian sea level 
changes could also have been glacio-eustatic, but driven by local mountain glaciers, given the strong evidence for a global eustatic origin and global $\delta^{13} \mathrm{C}$ signatures that require significant changes in climate and global oceanographic circulation. Water depths on the Middle and Late Silurian ramp were commonly sufficiently deep to inhibit exposure during most sea level falls, except over buildups.

Conformable surfaces between sequences on the inner ramp likely are not correlative conformities (equivalent to updip sequence boundaries). They are more likely to be transgressive surfaces (not to be confused with maximum flooding surfaces) on lowstand subtidal carbonates (typically wacke-packstone). This posed a challenge in applying the standard sequence stratigraphic model to the succession, in which sequence boundaries are the traceable surfaces (Van Wagoner et al., 1988). Lowstand systems tracts on the Wabash Platform are recorded on the deep ramp slope by carbonate prone, non-cherty skeletal wackestone, and by rare grainstone-packstone.

The transgressive systems tracts on the ramp are dominated by upward deepening wackestone up into variably argillaceous mudstone, and reflect eustatic sea level rise outpacing sedimentation with only a small contribution from driving subsidence. The Wabash Platform highstand systems tracts are upward shallowing successions, from carbonate mudstone grading up into subtidal wackestone and then wacke-packstone (which may be lowstand deposits). Sequence-capping, cross-bedded grainstones and peritidal laminites generally are absent within the study area (except on local buildups), and reflect incomplete shallowing and unfilled accommodation due to low sedimentation rates.

The few buildup cores examined in the study are dominated by upward 
shallowing sequences and parasequences of carbonate mudstone, stromatactis- and stromatoporoid- lime mudstone/wackestone, and crinoidal packstone-grainstone flank beds. Buildups only locally have a rigid, interlocking skeletal framework. The major buildups were not initiated until the Ludlow and continued through the Pridoli. Buildup development appears to have been concurrent with increased accommodation space, perhaps due to flexuring peripheral to the Jessamine Dome (Okla, 1976), global warming and aridification of the climate, which may have increased nutrient availability along the bank margins in this nutrient starved setting. The later Silurian ramp with its mid-ramp barrier banks, contrasts with the earlier Silurian homoclinal ramp with its strongly layer cake character and limited facies differentiation.

Hardgrounds are not confined to a single sequence stratigraphic position and are not regionally traceable. They were developed locally on sequence boundaries, on maximum flooding surfaces, as well as within transgressive and highstand systems tracts. This somewhat random distribution is analogous to that described from the Tertiary of North Carolina (Coffey and Read, 2004). Both are characterized by very low sedimentation rates, associated glauconite and frequent shut-down of the carbonate factory.

Positive carbon isotope excursions have been documented by other workers from elsewhere at the supersequence bounding, Ordovician-Silurian and Silurian-Devonian unconformities, and from early highstand strata just above the Osgood, Waldron and Mississinewa "shales" (Azmy et al., 1998; Cramer and Saltzman, 2005; 2007; Saltzman, 2001; 2002). These global signals indicate global (rather than local) causes compatible with eustatic sea level and climate changes having controlled sequence development. 
The latest Ordovician-Early Silurian icehouse on this sediment starved, very lowaccommodation platform is manifested in disconformity-bounded Early Silurian third order sequences with very few fourth order parasequences; in higher accommodation settings in the Great Basin, U.S.A., sequences have numerous fourth-order parasequences, compatible with transitional eustacy and moderate ice sheets (Read et al., 1995). Later Silurian, global greenhouse conditions are compatible with the smaller third order sea level changes and conformable sequences. However, the low accumulation rates and unfilled accommodation prevented the recording of many fifth-order small high frequency sea level cycles. However, many small precessional cycles typical of greenhouse climate are recorded in the peritidal facies of this age in the more rapidly accumulating Appalachian Basin succession. 


\section{REFERENCES}

Al-Tawil, A., T. C. Wynn, and J. F. Read, 2003, Sequence response of a distal-toproximal foreland ramp to glacio-eustasy and tectonics; Mississippian, Appalachian Basin, West Virginia-Virginia, U.S.A: Special Publication - Society for Sedimentary Geology, v. 78, p. 11-34.

Allison, P. A., and V. P. Wright, 2005, Switching off the carbonate factory; A-tidality, stratification and brackish wedges in epeiric seas: Sedimentary Geology, v. 179, p. $175-184$.

Anderson, E. J., and P. W. Goodwin, 1990, The significance of metre-scale allocycles in the quest for a fundamental stratigraphic unit: Journal of the Geological Society of London, v. 147, p. 507-518.

Archer, A. W., D. J. Bottjer, J. B. Droste, A. S. Horowitz, S. M. Kelly, D. L. Krisher, and R. H. Shaver, 1980, Stratigraphy, structure, and zonation of large Silurian reef at Delphi, Indiana: AAPG Bulletin, v. 64, p. 115-131.

Archer, A. W., and H. R. Feldman, 1986, Microbioherms of the Waldron Shale (Silurian, Indiana); implications for organic framework in Silurian reefs of the Great Lakes area: Palaios, v. 1, p. 133-140.

Atkinson, M. J., S. V. Smith, and E. D. Stroup, 1981, Circulation in Enewetak Atoll: Limonol. Oceanogr., v. 26, p. 1074-1083.

Ault, C. H., L. E. Becker, J. B. Droste, S. Keller, and R. H. Shaver, 1992, Map of Indiana showing thickness of Silurian rocks and location of reefs.

Azmy, K., J. Veizer, M. G. Bassett, and P. Copper, 1998, Oxygen and carbon isotopic composition of Silurian brachiopods: Implications for coeval seawater and glaciations: GSA Bulletin, v. 110, p. 1499-1512.

Becker, L. E., 1974, Silurian and Devonian Rocks in Indiana Southwest of the Cincinnati Arch, Bulletin - Indiana, Geological Survey, no.50,, Bloomington, Indiana, p. 83.

Becker, L. E., and J. B. Droste, 1978, Late Silurian and Early Devonian Sedimentological History of Southwestern Indiana: Bloomington, IN, Indiana Geological Survey.

Bell, S. C., and R. Smosna, 1999, Regional facies analysis and carbonate ramp development in the Tonoloway Limestone (U. Silurian; Central Appalachians): 
Southeastern Geology, v. 38, p. 259-278.

Bickert, T., J. Patzold, C. Samtleben, and A. Munnecke, 1997, Paleoenvironmental changes in the Silurian indicated by stable isotopes in brachiopod shells from Gotland, Sweden: Geochimica et Cosmochimica acta, v. 61, p. 2717-2730.

Bosence, D., and D. Waltham, 1990, Computer modeling the internal architecture of carbonate platforms: Geology, v. 18, p. 26-30.

Boucot, A. J., 1962, Appalachian Siluro-Devonian, in K. Coe, ed., Some aspects of the Variscan fold belt v. 9th: Manchester, Manchester University Press.

Bourque, P.-A., 2001, Sea level, synsedimentary tectonics, and reefs; implications for hydrocarbon exploration in the Silurian-lowermost Devonian Gaspe Belt, Quebec Appalachians: Bulletin of Canadian Petroleum Geology, v. 49, p. 217-237.

Bourque, P.-A., M. Malo, and D. Kirkwood, 2000, Paleogeography and tectonosedimentary history at the margin of Laurentia during Silurian to earliest Devonian time; the Gaspe Belt, Quebec: Geological Society of America Bulletin, v. 112 , p. $4-20$.

Brenchley, P. J., J. D. Marshall, G. A. F. Carden, D. B. R. Robertson, D. G. F. Long, T. Meidla, L. Hints, and T. F. Anderson, 1994, Bathymetric and isotopic evidence for a short-lived Late Ordovician glaciation in a greenhouse period: Geology, v. 22, p. 295-298.

Brett, C. E., 1999, Wenlockian fossil communities in New York State and adjacent areas paleontology and paleocology: World and Regional Geology, v. 11, p. 592-637.

Brett, C. E., W. M. Goodman, and S. T. LoDuca, 1990, Sequences, cycles, and basin dynamics in the Silurian of the Appalachian foreland basin: Sedimentary Geology, v. 69, p. 191-244.

Brown, J., A. Colling, D. Park, J. Phillips, D. Rothery, and J. Wright, 1989, Ocean Circulation: Oxford, England, The Open University.

Burke, K., and J. F. Dewey, 1973, Plume-generated triple junctions: key indicators in applying plate tectonics to old rocks: Journal of Geology, v. 81, p. 406-433.

Caputo, M. V., 1998, Ordovician-Silurian Glaciations and Global Sea-Level Changes, in E. Landing, and M. E. Johnson, eds., Silurian Cycles: Linkages of Dynamic 
Stratigraphy with Atmospheric, Oceanic, and Tectonic Chanes: Albany, NY, The New York State Education Department.

Caputo, M. V., and J. C. Crowell, 1985, Migration of glacial centers across Gondwana during Paleozoic Era: GSA Bulletin, v. 96, p. 1020-1036.

Cawood, P. A., J. A. M. van Gool, and G. R. Dunning, 1995, Collisional tectonics along the Laurentian margin of the Newfoundland Appalachians, in J. P. Hibbard, C. R. van Staal, and P. A. Cawood, eds., Special Paper - Geological Association of Canada, vol.41, p. 283-301.

Coburn, G. W., 1986, Silurian of Illinois Basin; a carbonate ramp, AAPG Bulletin, v. 70, p. 575.

Cocks, L. R. M., and T. H. Torsvik, 2002, Earth geography from 500 to 400 million years ago; a faunal and palaeomagnetic review: Journal of the Geological Society of London, v. 159, p. 631-644.

Coffey, B. P., and J. F. Read, 2004, Mixed carbonate-siliciclastic sequence stratigraphy of a Paleogene transition zone continental shelf, southeastern USA: Sedimentary Geology, v. 166, p. 21-57.

Copper, P., 2002, Silurian and Devonian reefs; 80 million years of global greenhouse between two ice ages: Special Publication - Society for Sedimentary Geology, v. 72, p. 181-238.

Cramer, B. D., and M. R. Saltzman, 2005, Sequestration of (super 12) C in the deep ocean during the early Wenlock (Silurian) positive carbon isotope excursion: Palaeogeography, Palaeoclimatology, Palaeoecology, v. 219, p. 333-349.

Cramer, B. D., and M. R. Saltzman, 2007, Fluctuations in epeiric sea carbonate production during Silurian positive carbon isotope excursions; a review of proposed paleoceanographic models, in A. Munnecke, and T. Servais, eds., Palaeogeography, Palaeoclimatology, Palaeoecology, v. 245, p. 37-45.

Cramer, B. D., M. R. Saltzman, and M. A. Kleffner, 2006, Spatial and temporal variability in organic carbon burial during global positive carbon isotope excursions; new insight from high resolution delta (super 13) C (sub carb) stratigraphy from the type area of the Niagaran (Silurian) Provincial Series: 
Stratigraphy, v. 2, p. 327-340.

Crowell, J. C., 1983, Ice ages recorded on Gondwanan continents: Transactions of the Geological Society of South Africa, v. 86, p. 238-262.

Crowell, J. C., 1999, Pre-Mesozoic ice ages; their bearing on understanding the climate system: Geological Society of America Memoir, v. 192, Geological Society of America, $106 \mathrm{p}$.

Davies, G. R., 1970, Carbonate bank sedimentation, eastern Shark bay, Western Australia: Memoir - American Association of Petroleum Geologists, v. 13, p. 85168.

Demicco, R. V., and L. A. Hardie, 2002, The "carbonate factory" revisited; a reexamination of sediment production functions used to model deposition on carbonate platforms: Journal of Sedimentary Research, v. 72, p. 849-857.

Desrochers, A., 2006, Rocky shoreline deposits in the Lower Silurian (upper Llandovery, Telychian) Chicotte Formation, Anticosti Island, Quebec, in D. Rudkin, and M. E. Johnson, eds., Canadian Journal of Earth Sciences $=$ Revue Canadienne des Sciences de la Terre, v. 43, p. 1205-1214.

Dorobek, S. L., 1987, Petrography, geochemistry, and origin of burial diagenetic facies, Siluro-Devonian Helderberg Group (carbonate rocks), central Appalachians: AAPG Bulletin, v. 71, p. 492-514.

Dorobek, S. L., and J. F. Read, 1986, Sedimentology and basin evolution of the SiluroDevonian Helderberg Group, Central Appalachians: Journal of Sedimentary Petrology, v. 56, p. 601-613.

Dorsch, J., R. K. Bambach, and S. G. Driese, 1994, Basin-rebound origin for the "Tuscarora unconformity" in southwestern Virginia and its bearing on the nature of the Taconic Orogeny: American Journal of Science, v. 294, p. 237-255.

Droste, J. B., and R. H. Shaver, 1977, Synchronization of deposition; Silurian reefbearing rocks on Wabash Platform with cyclic evaporites of Michigan Basin, in J. H. Fisher, ed., Reefs and evaporites- Concepts and depositional models; Studies in Geology v. 5, p. 93-109.

Droste, J. B., and R. H. Shaver, 1980, Recognition of Buried Silurian Reefs in 
Southwestern Indiana: Application to the Terre Haute Bank: Journal of Geology, v. 88 , p. $567-587$.

Droste, J. B., and R. H. Shaver, 1982, The Salina Group (Middle and Upper Silurian) of Indiana, Special Report - Indiana, Geological Survey, Volume 24, Bloomington, Indiana, Indiana Geological Survey, p. 41.

Droste, J. B., and R. H. Shaver, 1987a, Paleoceanography of Silurian seaways in the Midwestern basins and arches region, in R. M. Feldmann, ed., Paleoceanography, v. 2, p. 213-227.

Droste, J. B., and R. H. Shaver, 1987b, Upper Silurian and Lower Devonian Stratigraphy of the Central Illinois Basin, Special Report - Indiana, Geological Survey, Bloomington, Indiana, p. 29.

Droste, J. B., R. H. Shaver, and J. L. Wilson, 1985, Comparative stratigraphic framework for Silurian reefs; Michigan Basin to surrounding platforms, in K. R. Cercone, and J. M. Budai, eds., Special Papers - Michigan Basin Geological Society, vol.4, p. 73-93.

Dunning, G. R., S. J. O'Brien, S. P. Colman-Sadd, R. F. Blackwood, W. L. Dickson, P. P. O'Neill, and T. E. Krogh, 1990, Silurian orogeny in the Newfoundland Appalachians: Journal of Geology, v. 98, p. 895-913.

Ettensohn, F. R., 1994, Tectonic control on formation and cyclicity of major Appalachian unconformities and associated stratigraphic sequences, in J. M. Dennison, and F. R. Ettensohn, eds., Concepts in Sedimentology and Paleontology, vol.4, p. 217242.

Ettensohn, F. R., and C. E. Brett, 1998, Tectonic components in third-order Silurian cycles; examples from the Appalachian Basin and global implications: Bulletin New York State Museum (1976), v. 491, p. 145-162.

Faill, R. T., 1997a, A geologic history of the north-central Appalachians; Part 1, Orogenesis from the Mesoproterozoic through the Taconic Orogeny: American Journal of Science, v. 297, p. 551-619.

Faill, R. T., 1997b, A geologic history of the north-central Appalachians; Part 2, The Appalachian Basin from the Silurian through the Carboniferous: American 
Journal of Science, v. 297, p. 729-761.

Feldman, H. R., 1989, Taphonomic processes in the Waldron Shale, Silurian, southern Indiana: Palaios, v. 4, p. 144-156.

Fischer, A., 1983, Milankovitch and climate: Episodes, v. 1983.

Frakes, L. A., J. E. Francis, and J. I. Syktus, 1992, Climate modes of the Phanerozoic; the history of the earth's climate over the past 600 million years: Cambridge, United Kingdom (GBR), Cambridge Univ. Press.

Gischler, E., 2003, Holocene lagoonal development in the isolated carbonate platforms off Belize, in P. Blanchon, and L. Montaggioni, eds., Sedimentary Geology, v. 159, p. 113-132.

Goldhammer, R. K., P. A. Dunn, and L. A. Hardie, 1990, Depositional cycles, composite sea-level changes, cycle stacking patterns, and the hierarchy of stratigraphic forcing; examples from Alpine Triassic platform carbonates: Geological Society of America Bulletin, v. 102, p. 535-562.

Golonka, J., 2002, Plate-tectonic maps of the Phanerozoic: Special Publication - Society for Sedimentary Geology, v. 72, p. 21-75.

Goodman, W. M., and C. E. Brett, 1994, Roles of eustasy and tectonics in development of Silurian stratigraphic architecture of the Appalachian foreland basin, Concepts in Sedimentology and Paleontology, v. 4, p. 147-169.

Grahn, Y., and M. Caputo, 1992, Early Silurian glaciations in Brazil: Palaeogeography, Palaeoclimatology, Palaeoecology, v. 99, p. 9-15.

Hagan, G. M., and B. W. Logan, 1974, Development of Carbonate Banks and Hypersaline basins, Shark Bay, Western Australia: Memoir - American Association of Petroleum Geologists, v. 22, p. 61-139.

Harris, M. T., J. J. Kuglitsch, R. Watkins, D. P. Hegrenes, and K. R. Waldhuetter, 1998, Early Silurian stratigraphic sequences of eastern Wisconsin: Bulletin - New York State Museum (1976), v. 491, p. 39-49.

Harris, M. T., and P. M. Sheehan, 1998, Early Silurian stratigraphic sequences of the eastern Great Basin (Utah and Nevada): Bulletin - New York State Museum (1976), v. 491, p. 51-61. 
Heidlauf, D. T., A. T. Hsui, and G. d. Klein, 1986, Tectonic subsidence analysis of the Illinois Basin: Journal of Geology, v. 94, p. 779-794.

Herrmann, A. D., B. J. Haupt, M. E. Patzkowsky, D. Seidov, and R. L. Slingerland, 2004, Response of Late Ordovician paleoceanography to changes in sea level, continental drift, and atmospheric pCO (sub 2); potential causes for long-term cooling and glaciation, in M. C. Pope, and M. T. Harris, eds., Palaeogeography, Palaeoclimatology, Palaeoecology, v. 210, p. 385-401.

Holmden, C., R. A. Creaser, K. Muehlenbachs, S. A. Leslie, and S. M. Bergstrom, 1998, Isotopic evidence for geochemical decoupling between ancient epeiric seas and bordering oceans; implications for secular curves: Geology, v. 26, p. 567-570.

Husseini, M. I., 1990, The Cambro-Ordovician Arabian and Adjoining Plates: A GlacioEustatic Model: Journal of Petroleum Geology, v. 13, p. 267-288.

Jeppsson, L., M. G. Bassett, and P. D. Lane, 1990, An oceanic model for lithological and faunal changes tested on the Silurian record, Journal of the Geological Society of London, v. 147, p. 663-674.

Johnson, M. E., 1996, Stable Cratonic Sequences and a Standard for Silurian Eustasy, in B. J. Witzke, G. A. Ludvigson, and J. Day, eds., Paleozoic Sequence Stratigraphy: Views from the North American Craton: GSA Special Paper, v. 306: Boulder, Geological Society of America, p. 203-211.

Johnson, M. E., B. G. Baarli, H. Nestor, M. Rubel, and D. Worsley, 1991, Eustatic sealevel patterns from Lower Silurian (Llandovery Series) of southern Norway and Estonia: Geological Society of America Bulletin, v. 103, p. 315-335.

Johnson, M. E., R. Jia-Yu, and S. Kershaw, 1998a, Calibrating Silurian Eustasy Against the Erosion and Burial of Coastal Paleotography, in E. Landing, and M. E. Johnson, eds., Silurian Cycles: Linkages of Dynamic Stratigraphy with Atmospheric, Oceanic, and Tectonic Chanes: Albany, NY, The New York State Education Department.

Johnson, M. E., and W. S. McKerrow, 1991, Sea level and faunal changes during the latest Llandovery and Earlist Ludlow (Silurian): Historical Biology, v. 5, p. 153169. 
Johnson, M. E., J. Rong, and S. Kershaw, 1998b, Calibrating Silurian eustasy against the erosion and burial of coastal paleotopography: Bulletin - New York State Museum (1976), v. 491, p. 3-13.

Kahle, C. F., 1988, Surface and subsurface paleokarst, Silurian Lockport, and Peebles Dolomites, western Ohio, in N. P. James, and P. W. Choquette, eds.: New York, Springer-Verlag.

Kaljo, D., T. Martma, P. Mannik, and V. Viira, 2003, Implications of Gondwana glaciations in the Baltic Late Ordovician and Silurian and a carbon isotopic test of environmental cyclicity: Bulletin de la Societe Geologique de France, v. 174, p. 59-66.

Kleffner, M. A., 1995, A conodont- and graptolite-based Silurian chronostratigraphy: Special Publication - SEPM v. 53, p. 159-176.

Kleffner, M. A., 1998, Wenlock conodont chronostratigraphy and sequences of the Appalachian Basin in New York, Ohio, and Tennessee, AAPG Bulletin, v. 82, p. 1769.

Kluessendorf, J., and D. G. Mikulic, 1996, An Early Silurian sequence boundary in Illinois and Wisconsin: Special Paper - Geological Society of America, v. 306, p. 177-185.

Koerschner, W. F., III, and J. F. Read, 1989, Field and modelling studies of Cambrian carbonate cycles, Virginia, Appalachians: Journal of Sedimentary Petrology, v. 59 , p. 654-687.

Kolata, D. R., and W. J. Nelson, 1990, Basin-forming mechanisms of the Illinois Basin: AAPG Memoir, v. 51, p. 287-292.

Kriz, J., 1991, The Silurian of the Prague Basin (Bohemia); tectonic, eustatic and volcanic controls on facies and faunal development, in M. G. Bassett, P. D. Lane, and D. Edwards, eds., Special Papers in Palaeontology, vol.44, p. 179-203.

Kruger, J. M., 1993, Deposition and diagenesis of the lower Tippecanoe II Sequence (Upper Ordovician to Lower Silurian), Illinois Basin: Doctoral thesis, University of Wisconsin at Madison, Madison, WI, United States (USA).

Kruger, J. M., and J. A. Simo, 1994, Pervasive dolomitization of a subtidal carbonate 
ramp, Silurian and Devonian, Illinois Basin, USA: Special Publication of the International Association of Sedimentologists, v. 21, p. 387-405.

Lane, N. G., and W. I. Ausich, 1995, Interreef crinoid fauna from the Mississinewa Shale Member of the Wabash Formation (northern Indiana; Silurian; Echinodermata): Journal of Paleontology, v. 69, p. 1090-1106.

Logan, B. W., and D. E. Cebulski, 1970, Sedimentary environments of Shark bay, Western Australia: Memoir - American Association of Petroleum Geologists, v. 13 , p. 1-37.

Lowenstam, H. A., 1950, Niagaran reefs of the Great Lakes area: Journal of Geology, v. 58, p. $430-487$.

Lowenstam, H. A., 1957, Niagaran reefs in the Great Lakes area, Chapter 10 of Ladd, H. S., ed., Paleoecology.

Melchin, M. J., and C. Holmden, 2006, Carbon isotope chemostratigraphy in Arctic Canada; sea-level forcing of carbonate platform weathering and implications for Hirnantian global correlation: Palaeogeography, Palaeoclimatology, Palaeoecology, v. 234, p. 186-200.

Mesolella, K. J., J. D. Robinson, L. M. McCormick, and A. R. Ormiston, 1976, Cyclic Deposition of Silurian Carbonates and Evaporites in Michigan Basin, Silurian Reeds of Great Lakes Region of North America: Tulsa Oklahoma, The American Association of Petroleum Geologists.

Mikulic, D. G., 1990, Tippecanoe II Subsequence; Silurian System through Lower Devonian Series: AAPG Memoir, v. 51, p. 101-107.

Mikulic, D. G., and J. Kluessendorf, 1994, The classic Silurian reefs of the Chicago area, in J. Grace, ed.: Department of Geology, Western Michigan University.

Mikulic, D. G., and J. Kluessendorf, 1999, The classic Silurian reefs of the Chicago area: Champaign, IL, Guidebook Series - Illinois State Geological Survey, 57 p.

Mikulic, D. G., and J. Kluessendorf, 2001, Geology of the Silurian Rocks, in J. Lasemi, and R. C. Berg, eds., Three-dimensional Geologic Mapping: A Pilot Program for Resource and Environmental Assessment in the Villa Grove Quadrangle, Douglas County, Illinois: Illinois State Geological Survery Bulletin, v. 106: Champaign, 
Illinois, Illinois State Geological Survery, p. 118.

Milner, S., R. T. Buffler, R. E. Farmer, and D. K. Clark, 1975, Stratigraphic atlas of North and Central America: Princeton Univ. Press.

Moore, G. T., S. R. Jacobson, C. A. Ross, and D. N. Hayashida, 1994, A paleoclimate simulation of the Wenlockian (late Early Silurian) world using a general circulation model with implications for early land plant paleoecology: Palaeogeography, Palaeoclimatology, Palaeoecology, v. 110, p. 115-144.

Nicoll, R. S., and C. B. Rexroad, 1968, Stratigraphy and conodont paleontology of the Salamonie Dolomite and Lee Creek Member of the Brassfield Limestone (Silurian) in southeastern Indiana and adjacent Kentucky, Bulletin - Indiana, Geological Survey, p. 73.

Okla, S. M., 1976, Subsurface stratigraphy and sedimentation of middle and upper Silurian rocks of northern Indiana: Doctoral thesis, Indiana University at Bloomington, Bloomington, $143 \mathrm{p}$.

Perry, T. G., and D. E. Hattin, 1960, Osgood (Niagaran) bryozoans from the type area [Indiana]: Journal of Paleontology, v. 34, p. 695-710.

Pinsak, A. P., and R. H. Shaver, 1964, The Silurian formation of northern Indiana: Indiana Geological Survey Bull., v. 72, p. 1195-1250.

Pollock, C. A., and C. B. Rexroad, 1973, Conodonts from the Salina Formation and the Upper Part of the Wabash Formation (Silurian) in North-Central Indiana: Geologica et Palaeontologica, v. 7, p. 77-85.

Pope, M. C., and J. B. Steffen, 2003, Widespread, prolonged late Middle to Late Ordovician upwelling in North America; a proxy record of glaciation?: Geology, v. 31, p. 63-66.

Powell, J. H., B. K. Moh'd, and A. Masri, 1994, Late Ordovician - Early Silurian glaciofluvial deposits preserved in palaeovalleys in South Jordan: Sedimentary Geology, v. 89, p. 303-314.

Quinlan, G. M., and C. Beaumont, 1984, Appalachian thrusting, lithospheric flexure, and the Paleozoic stratigraphy of the Eastern Interior of North America: Can. Journal of Earth Science, v. 21, p. 973-996. 
Read, J. F., J. F. Read, C. Kerans, L. J. Weber, J. F. Sarg, and F. M. Wright, 1995, Overview of carbonate platform sequences, cycle stratigraphy and reservoirs in greenhouse and icehouse worlds: SEPM Short Course Notes, v. 35, p. 102.

Rexroad, C. B., 1980, Field trip 1; Silurian stratigraphy and conodont paleontology, southeastern Indiana, in R. H. Shaver, ed., Field Trips 1980 from the Indiana University Campus, Bloomington: Bloomington, Indiana, Indiana Geol. Survey, Indiana, United States

Rexroad, C. B., A. V. Noland, and C. A. Pollock, 1978, Conodonts from the Louisville Limestone and the Wabash Formation (Silurian) in Clark County, Indiana and Jefferson County, Kentucky Special Report - Indiana, Geological Survey; no 16, Bloomington, Indiana, p. 19.

Sadler, P. M., 1981, Sediment accumulation rates and the completeness of stratigraphic sections: Journal of Geology, v. 89, p. 569-584.

Saltzman, M. R., 2001, Silurian delta ${ }^{13}$ C stratigraphy: A view from North America: Geology, v. 29, p. 671-674.

Saltzman, M. R., 2002, Carbon isotope (delta (super 13) C) stratigraphy across the Silurian-Devonian transition in North America; evidence for a perturbation of the global carbon cycle: Palaeogeography, Palaeoclimatology, Palaeoecology, v. 187, p. 83-100.

Saltzman, M. R., 2005, Phosphorus, nitrogen, and the redox evolution of the Paleozoic oceans: Geology, v. 33, p. 573-576.

Schlager, W., 2003, Benthic carbonate factories of the Phanerozoic, in J. J. G. Reijmer, C. Betzler, and M. Mutti, eds., International Journal of Earth Sciences, v. 92, p. 445-464.

Schlager, W., 2005, Carbonate sedimentology and sequence stratigraphy: SEPM Concepts in Sedimentology and Paleontology, v. 8: Tulsa, Oklahoma, SEPM, 2000

Scotese, C. R., R. K. Bambach, C. Barton, R. Van der Voo, and A. M. Ziegler, 1979, Paleozoic base maps: Journal of Geology, v. 87, p. 217-277.

Scotese, C. R., and W. S. McKerrow, 1990, Revised world maps and introduction, in W. 
S. McKerrow, and C. R. Scotese, eds., Memoir - Geological Society of London, vol.12, p. 1-21.

Seale, G. L., 1985, Relationship of possible Silurian reef trend to middle Proterozoic stratigraphy and structure of the southern Illinois Basin of western Kentucky, Thesis Series - Kentucky Geological Survey, Report: 3, Lexington, KY, p. 63.

Shaver, R. H., 1974, Silurian Reefs of Northern Indiana: Reef and Interreef Macrofaunas: Bulletin of the American Association of Petroleum Geologists, v. 58, p. 934-956.

Shaver, R. H., 1984, Midwestern basin and arches correlation chart: Am. Assoc. Pet. Geol. Tulsa OK United States (USA).

Shaver, R. H., 1987, The Silurian reefs near Wabash, Indiana, in D. L. Biggs, ed.: Boulder, Geol. Soc. Am.

Shaver, R. H., C. H. Ault, W. I. Ausich, J. B. Droste, A. S. Horowitz, W. C. James, S. M. Okla, C. B. Rexroad, D. M. Suchomel, and J. R. Welch, 1978, The Search for a Silurian reef model; Great Lakes area, Special Report - Indiana, Geological Survey, p. 36.

Shaver, R. H., W. I. Ausich, and J. B. Droste, 1976, Search for Silurian reef model; Great Lakes area: AAPG Bulletin, v. 60, p. 684.

Shaver, R. H., and J. A. Sunderman, 1983, Silurian Reef and Interreef Stata as Responses to a Cyclical Succession of Environments, Southern Great Lakes Area (Field Trip 12), in R. H. Shaver, and J. A. Sunderman, eds., Field Trips in Midwestern Geology, v. 1, The Geological Society of America.

Shaver, R. H., and J. A. Sunderman, 1989, Silurian seascapes: Water depth, clinoforms, reef geometry, and other motifs- A critical review of the SIlurian reef model: Geological Society of America Bulletin, v. 101, p. 939-951.

Sieverding, J. L., 1981, Stratigraphy and Environmental Analysis of the Osgood Formation (Niagran), Southeastern Indiana: Master's thesis, Indiana University at Bloomington, Bloomington.

Sloss, L. L., 1988, Tectonic evolution of the craton in Phanerozoic time, in L. L. Sloss, ed.: Denver, Geol. Soc. Am. 
Smith, S. V., and M. J. Atkinson, 1984, Phosphorus limitation of net production in a confined aquatic ecosystem: Nature, v. 307, p. 626-627.

Smosna, R., 1988, Paleogeographic reconstruction of the Lower Devonian Helderberg Group in the Appalachian Basin, in N. J. McMillan, A. F. Embry, and D. J. Glan, eds., Memoir - Canadian Society of Petroleum Geologists, v. 14, p. 265-275.

Smosna, R., D. G. Patchen, S. M. Warshauer, and W. J. Perry, Jr., 1977, Relationships between depositional environments, Tonoloway Limestone, and distribution of evaporites in the Salina Formation, West Virginia.

Talent, J. A., R. Mawson, and A. Simpson, 2003, Silurian of Australia and New Guinea; biostratigraphic correlations and paleogeography, in E. Landing, and M. E. Johnson, eds., Bulletin - New York State Museum (1976), vol.493, p. 181-219.

Textoris, D. A., and A. V. Carozzi, 1964, Petrography and evolution of Niagaran (Silurian) reefs, Indiana: Bulletin of the American Association of Petroleum Geologists, v. 48, p. 397-426.

Tollefson, L. J. S., 1978, Paleoenvironmental analysis of the Kokomo and Kenneth limestone members of the Salina Formation in the vicinity of Logansport, Indiana Master's thesis, University of Illinois at Urbana-Champaign, Urbana, IL, United States (USA).

Torsvik, T. H., M. A. Smethurst, J. G. Meert, R. Van der Voo, W. S. McKerrow, M. D. Brasier, B. A. Sturt, and H. J. Walderhaug, 1996, Continental break-up and collision in the Neoproterozoic and Palaeozoic; a tale of Baltica and Laurentia: Earth-Science Reviews, v. 40, p. 229-258.

Vahrenkamp, V. C., P. K. Swart, and J. Ruiz, 1991, Episodic dolomitization of late Cenozoic carbonates in the Bahamas; evidence from strontium isotopes: Journal of Sedimentary Petrology, v. 61, p. 1002-1014.

Van Wagoner, J. C., H. W. Posamentier, R. M. Mitchum, Jr., P. R. Vail, J. F. Sarg, T. S. Loutit, and J. Hardenbol, 1988, An overview of the fundamentals of sequence stratigraphy and key definitions, in C. K. Wilgus, B. S. Hastings, C. A. Ross, H. W. Posamentier, J. Van Wagoner, and C. G. S. C. Kendall, eds., Special Publication - Society of Economic Paleontologists and Mineralogists, vol.42, p. 
$39-45$.

Wanless, H. R., D. J. Cottrell, M. G. Tagett, L. P. Tedesco, and E. R. Warzeski, Jr., 1995, Origin and growth of carbonate banks in South Florida: Special Publication of the International Association of Sedimentologists, v. 23, p. 439-473.

Witzke, B. J., 1987, Models for circulation patterns in epicontinental seas applied to Paleozoic facies of North America Craton, in R. M. Feldmann, ed., Paleoceanography, v. 2, p. 229-248.

Witzke, B. J., 1990, Palaeoclimate constraints for Palaeozoic Palaeolatitudes of Laurentia and Euramerica, in W. S. McKerrow, and C. R. Scotese, eds., Palaeozoic Palaeogeography and Biogeography: Memoir \#12, Geological Society of London.

Yang, W., S. J. Mazzullo, and C. S. Teal, 2004, Sediments, facies tracts, and variations in sedimentation rates of Holocene platform carbonate sediments and associated deposits, northern Belize; implications for "representative" sedimentation rates: Journal of Sedimentary Research, v. 74, p. 498-512.

Zuppann, C. W. K., Brian D; Keller, Stanley J, 1988, Geology and petroleum production of the Illinois Basin, v. 2: Champaign, Illinois, Illinois Geological Survey, 140 p. 


\section{FIGURES}

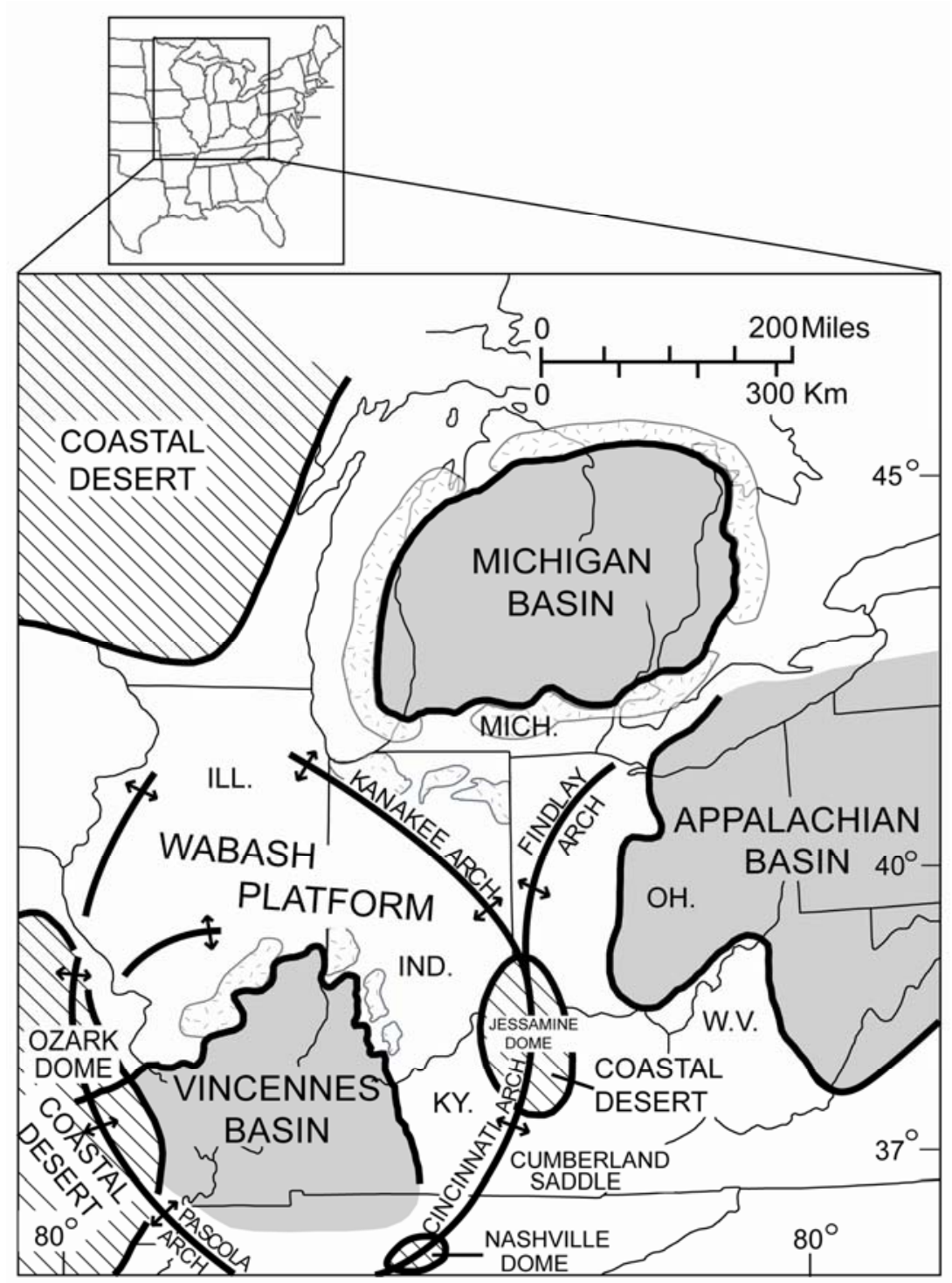

Fig. 1. Regional structure map, Wabash Platform, mid-continent, U.S.A. Location in eastern U.S. shown on inset map. Wabash Platform is bounded by "reefal" banks (Terre Haute and Fort Wayne banks) (stippled), Vincennes, Michigan and Appalachian basins (gray) and coastal deserts (diagonal lines). It is bordered by the Cincinnati and Findlay arches and Jessamine, Nashville and Ozark domes (modified from Shaver et al., 1978 and Seale, 1985). 


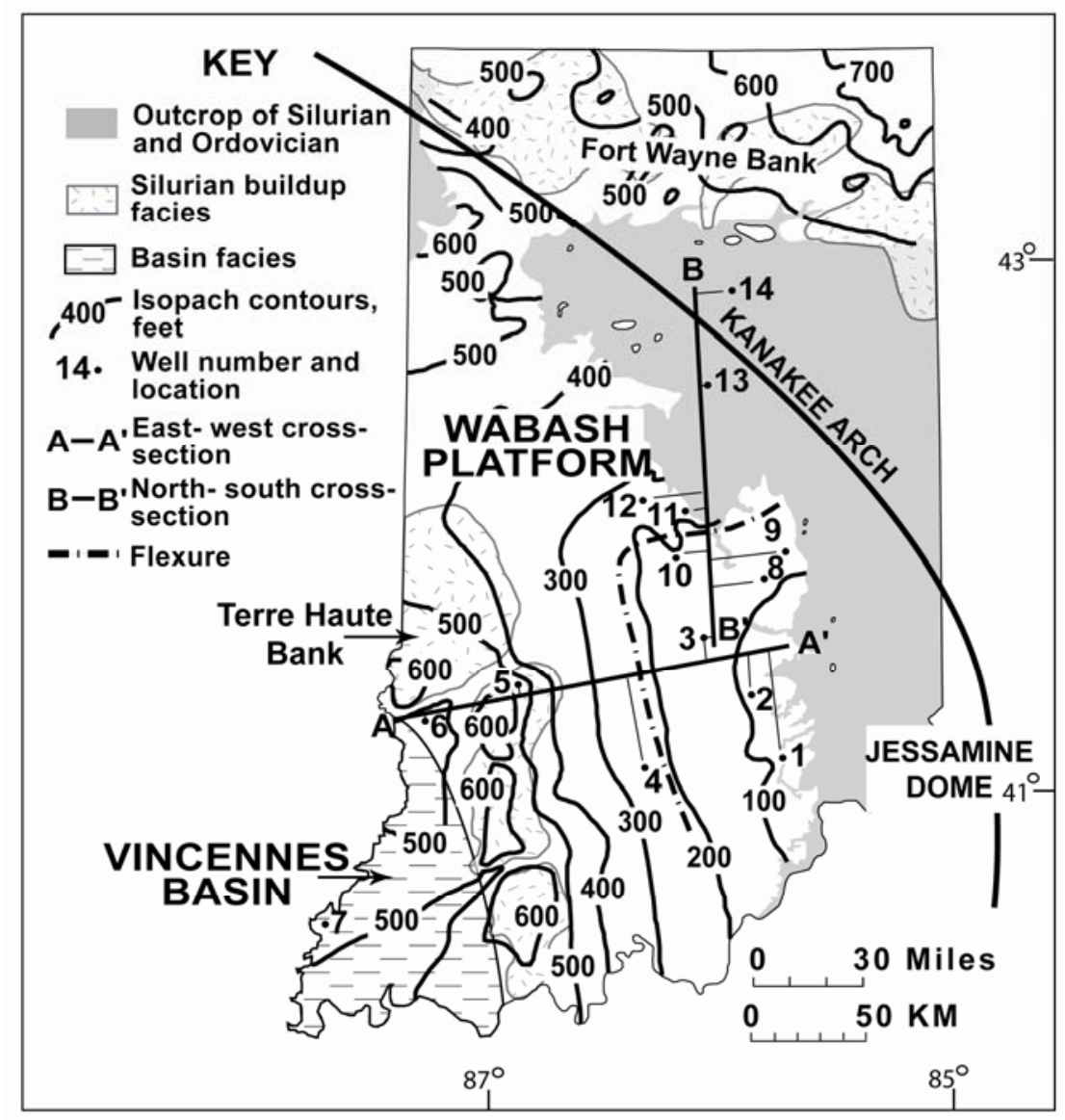

Fig. 2. Isopach map of Silurian strata, Indiana (modified from Ault et al., 1992). Reef trends (stippled), Vincennes (proto-Illinois) Basin, Michigan and Appalachian basins (dashed) and flexure (dash-dot line) are shown. Studied wells are relabeled as Well 1 (Well 131, Jennings Co.), Well 2 (Well 128, Bartholomew Co.), Well 3 (Well 125, Johnson Co.), Well 4 (Well 152, Lawrence Co.) Well 5 (Well 14, Owen Co.), Well 6 (Sullivan Co.), Well 7 (Gibson Co.), Well 8 (Well 493, Shelby Co.), Well 9 (Well 481, Rush Co.), Well 10 (Well 494, Marion Co.), Well 11 (Well 113, Marion Co.), Well 12 (Well 472, Boone Co.) Well 13 (Well 736, Howard Co.), and Well 14 (Well 416, Wabash Co.). Detailed well locations are given in Appendix I. 


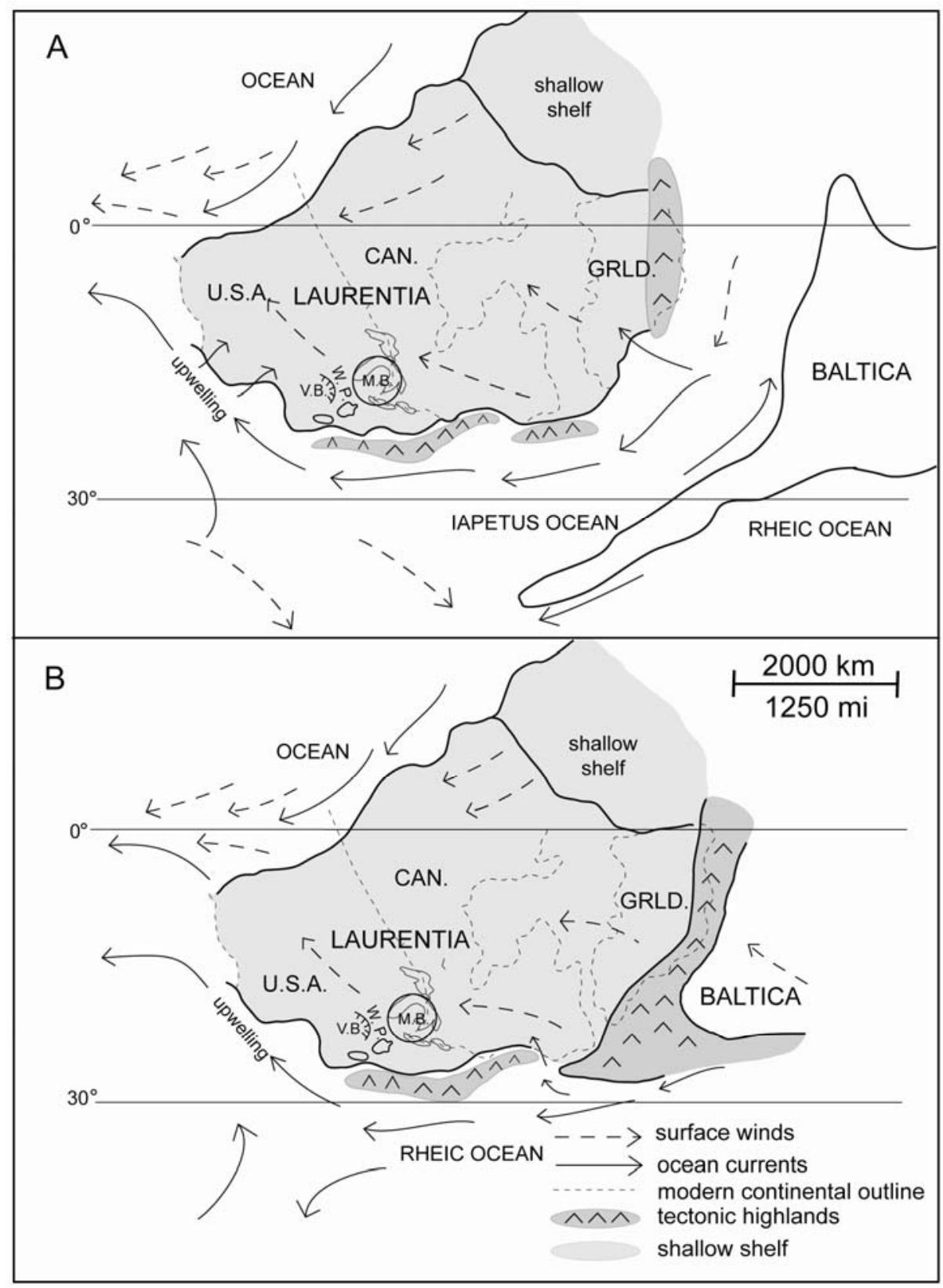

Fig. 3. Paleogeography of Laurentia during A. Early Silurian and B. Late Silurian.

Modern continental outlines are dashed. Winds (dashed arrows) and surface currents (solid arrows) shown. Drawn from data in Copper, (2002), Herrmann et al., (2002), Milner et al., (1975) and Moore et al. (1994). 


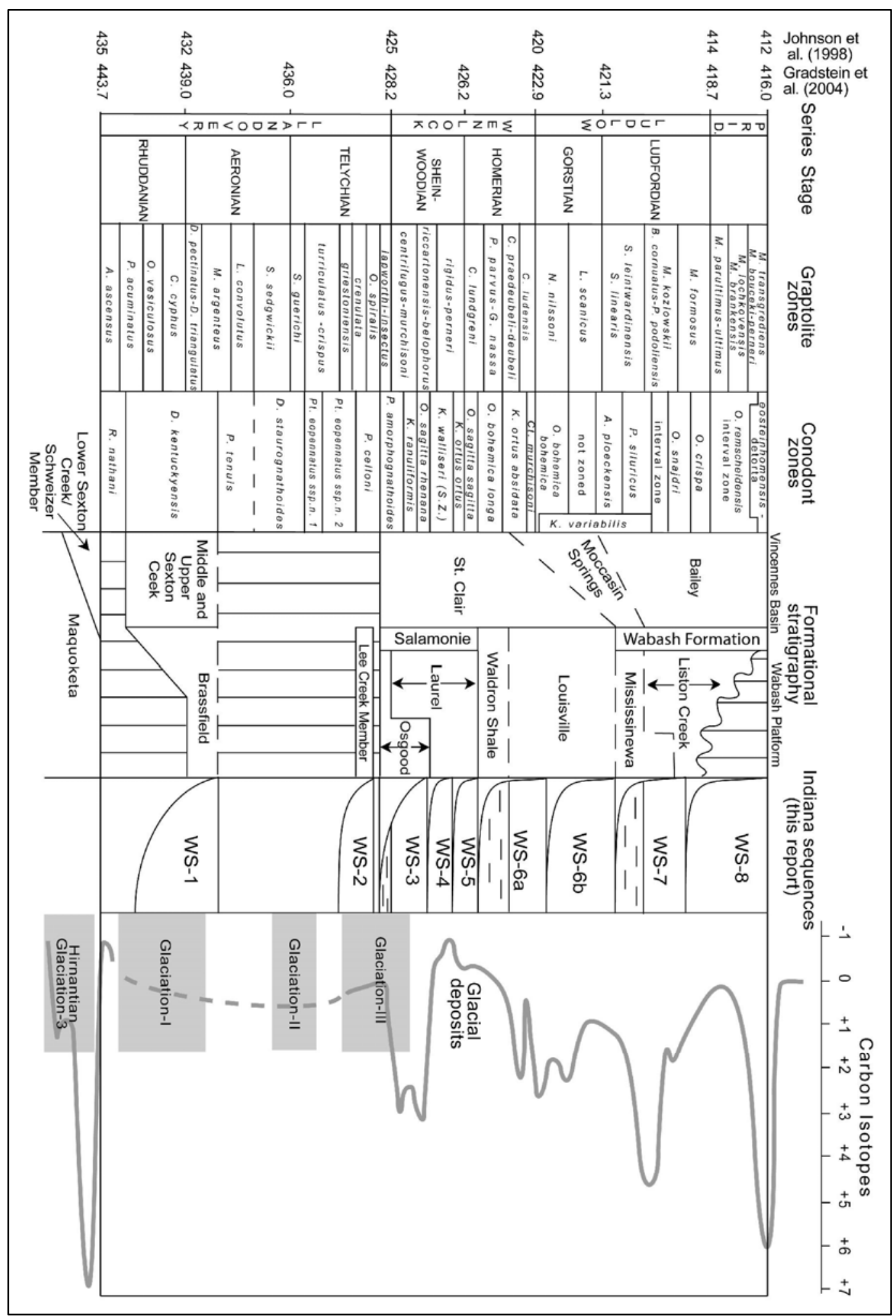


Fig. 4. Chronostratigraphic chart showing graptolite and conodont zones, formational stratigraphy (Nicoll and Rexroad, 1968; Becker, 1974; Rexroad et al., 1978; Rexroad, 1980; Sieverding, 1981; Shaver, 1984; Kleffner, 1998; Mikulic and Kluessendorf, 2001), timing of glacial deposits (Crowell, 1983; Caputo and Crowell, 1985; Grahn and Caputo, 1992; Caputo; 1998; Harris et al., 1998), carbon-isotope excursions from (Saltzman, 2001, 2002) and Indiana sequences, this study (numbering of Wabash Sequences tentative). Conodont zones were updated using data Kleffner, (1998) and Kleffner, (pers. com.). 


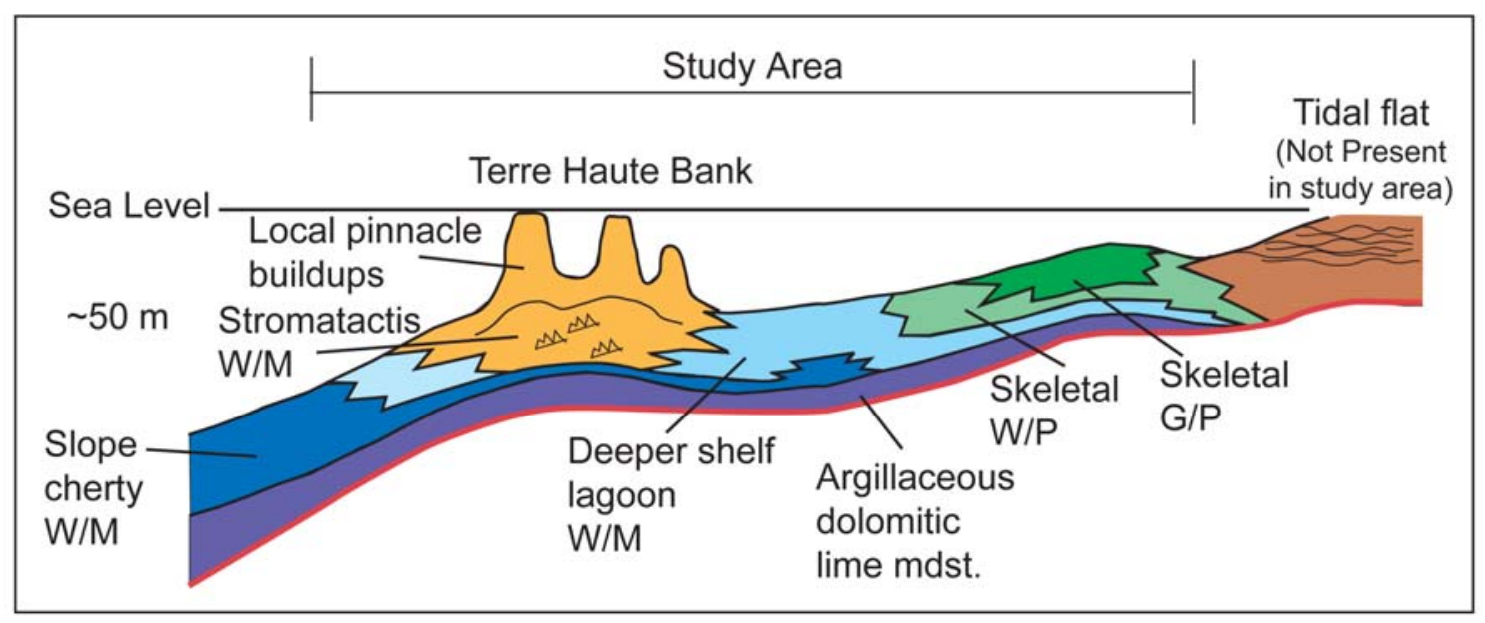

Fig. 5. Depositional profile showing the facies distribution on the Wabash Platform, Indiana. Transgressive facies of some sequences include argillaceous, (quartz-mica) carbonate mudstone (purple). The lack of peritidal facies in the study area is striking and the succession is dominated by subtidal facies. Buildups are absent from the Llandoverian. 


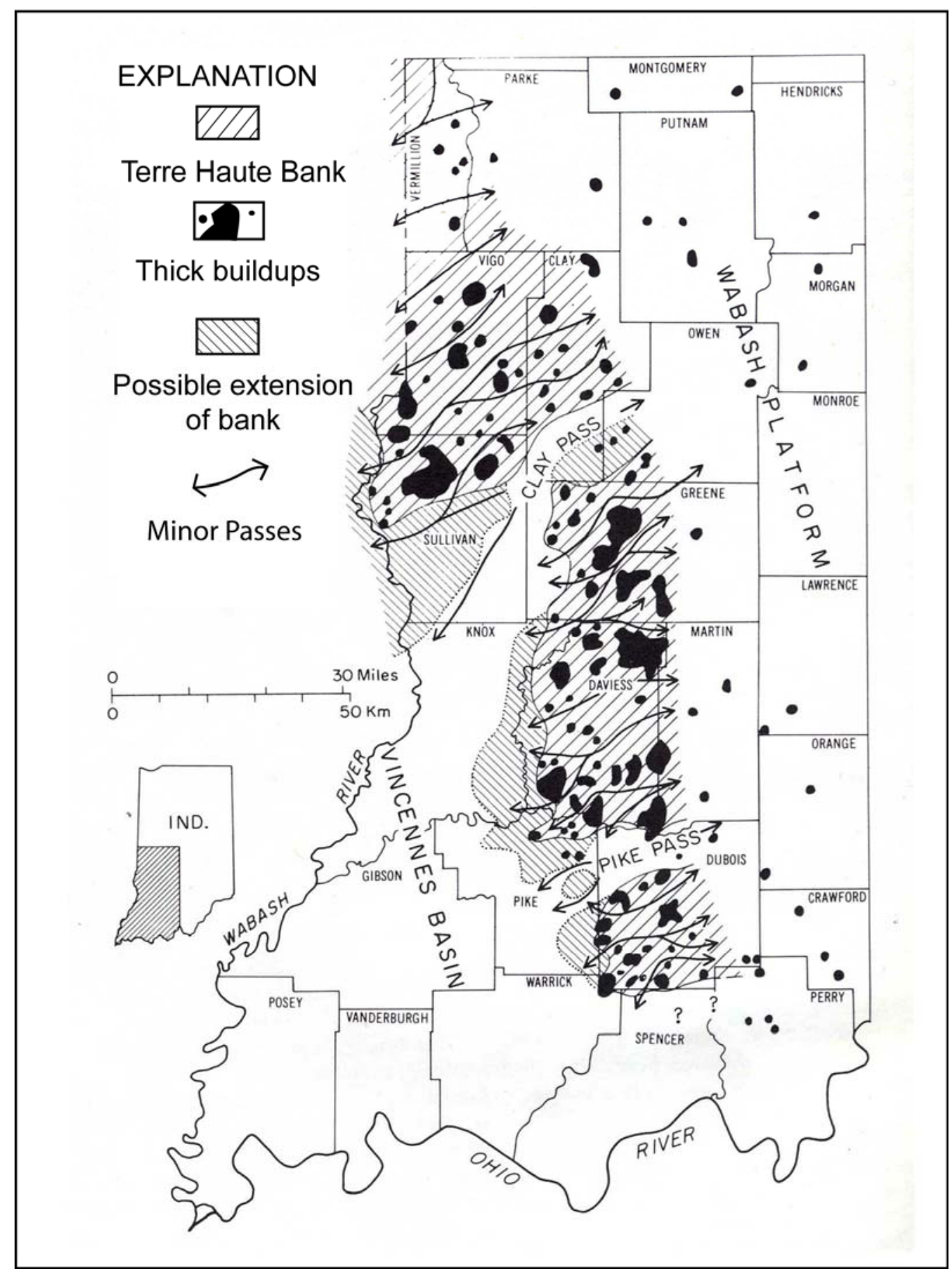

Fig. 6. Map showing structural drape of Middle Devonian unit over the top of the

Silurian carbonate; this map mimics the remnant topography on the platform at the end of the Silurian (Droste and Shaver, 1980). 

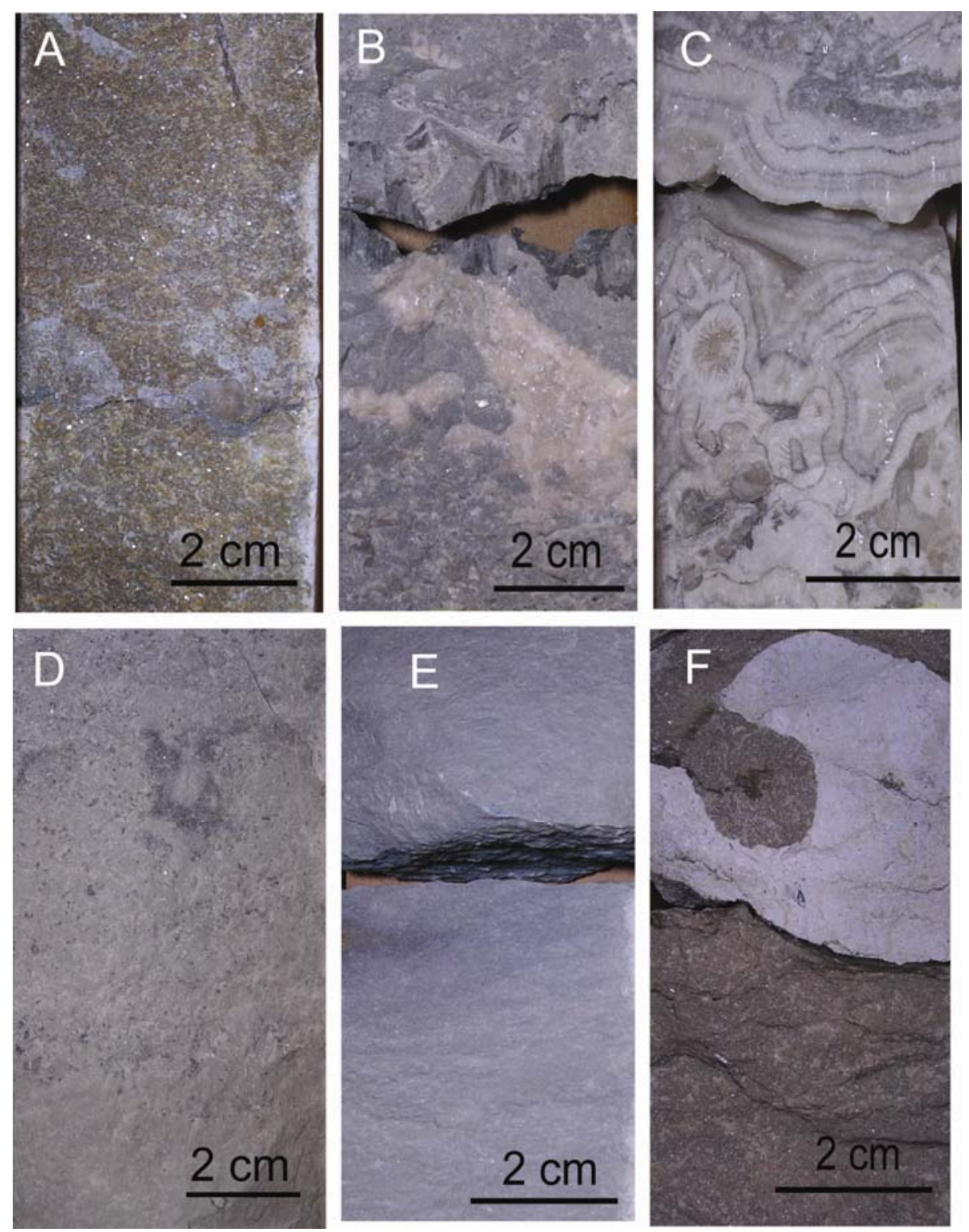

Fig. 7. Slab photographs of facies (scale shown on photographs): (A) crinoidal grainstone fom flat sheet-like units, Early Silurian, Well 1, $156 \mathrm{ft}$. deep; (B) stromatactisbearing wackestone from buildups, Late Silurian, Well 13, $181 \mathrm{ft}$. deep; (C) stromatoporoid boundstone from buildups, Late Silurian, Well 13, $150 \mathrm{ft}$. deep; (D) noncherty skeletal mudstone Well 3, $230 \mathrm{ft}$. deep; (E) transgressive, deep water, argillaceous carbonate mudstone Well 10, $285 \mathrm{ft}$. deep; (F) cherty mudstone Well 13, $430 \mathrm{ft}$. deep. 

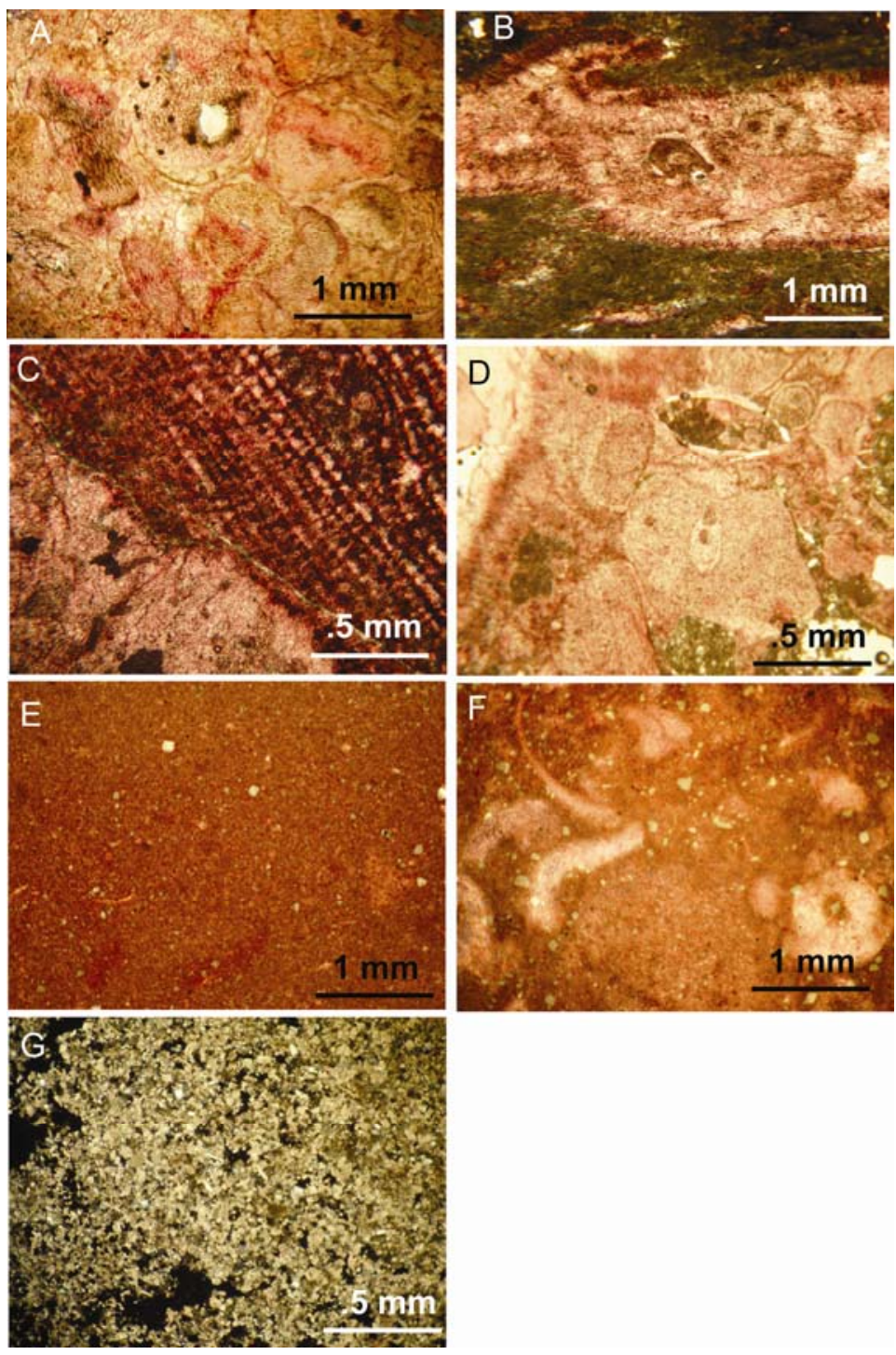

Fig. 8. Thin section photographs of facies (scale shown on photographs) (A) crinoid grainstone sheets form flat sheet-like units, Early Silurian, Well 1, $156 \mathrm{ft}$. deep; (B) stromatactis-bearing wackestone from buildups, Late Silurian, Well 13, $128 \mathrm{ft}$. deep; (C) stromatoporoid skeletal floatstone from buildups, Late Silurian, Well 13, 54 ft. deep; (D) crinoid rudstone from flank of buildups, Late Silurian, Well 13, $76 \mathrm{ft}$. deep; (E) noncherty mudstone Well 11, $202 \mathrm{ft}$. deep; (F) non-cherty skeletal wackestone Well 3, $257 \mathrm{ft}$. deep; and (G) transgressive, deep water, argillaceous dolomudstone, Well 3, $220 \mathrm{ft}$. deep. 
To Fort

\section{Wayne Bank}

\section{WELL 14
(सA16)
WABASCO}

Top Liston Creek

竞

क

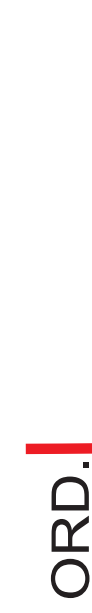

\section{WS-8}

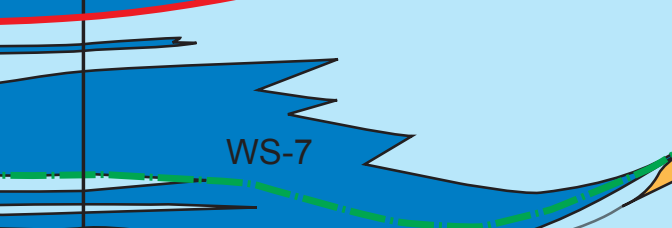

Top Mississinewa

$\frac{\text { WS-6b }}{\text { WS-6a }}$

WS-6a
Top Waldron Shale
WS-5.

WS-3 Osgood

ำ
$175 \mathrm{~km}$

ISOLATED BUILDUP

ATED BU
WELL 13
(H736)

\section{Wabash Platform}

$>$

\begin{tabular}{|c|c|c|c|c|c|c|}
\hline HOWARD CO. & $\begin{array}{c}\text { WELL 12 } \\
(\# 472) \\
\text { BOONE CO. }\end{array}$ & $\begin{array}{c}\text { WELL 11 } \\
\text { (\# 113) } \\
\text { MARION CO. }\end{array}$ & $\begin{array}{c}\text { WELL } 10 \\
\text { (\# 494) } \\
\text { MARION CO. }\end{array}$ & $\begin{array}{l}\text { WELL } 9 \\
\text { (\# 481) } \\
\text { RUSH CO. }\end{array}$ & $\begin{array}{c}\text { WELL } 8 \\
\text { (\# 493) } \\
\text { SHELBY CO. }\end{array}$ & $\begin{array}{c}\text { WELL 3 } \\
\text { (\# 125) } \\
\text { JOHNSON CO }\end{array}$ \\
\hline
\end{tabular}

Top Mississinewa Top Waldron Shale Top Louisville

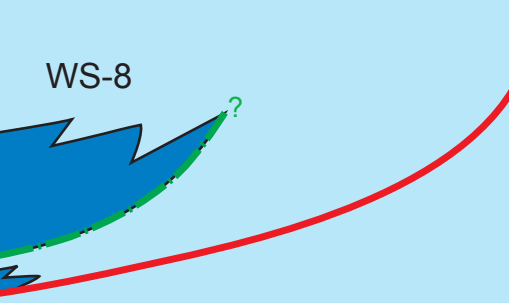

${ }_{2} 3+2+$

$2=-1=$

$+$

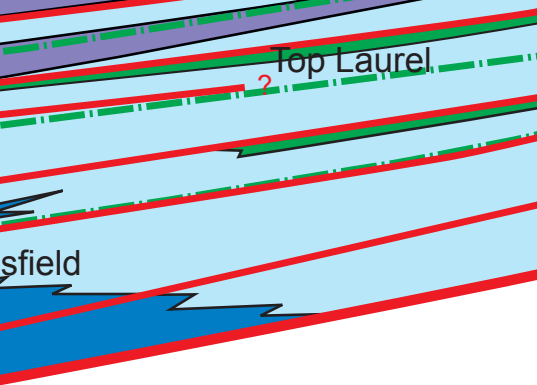

Top Brassfiel

$100 \mathrm{ft}$

$\sim 30 \mathrm{~m}$

$\sim 20 \mathrm{~km}$

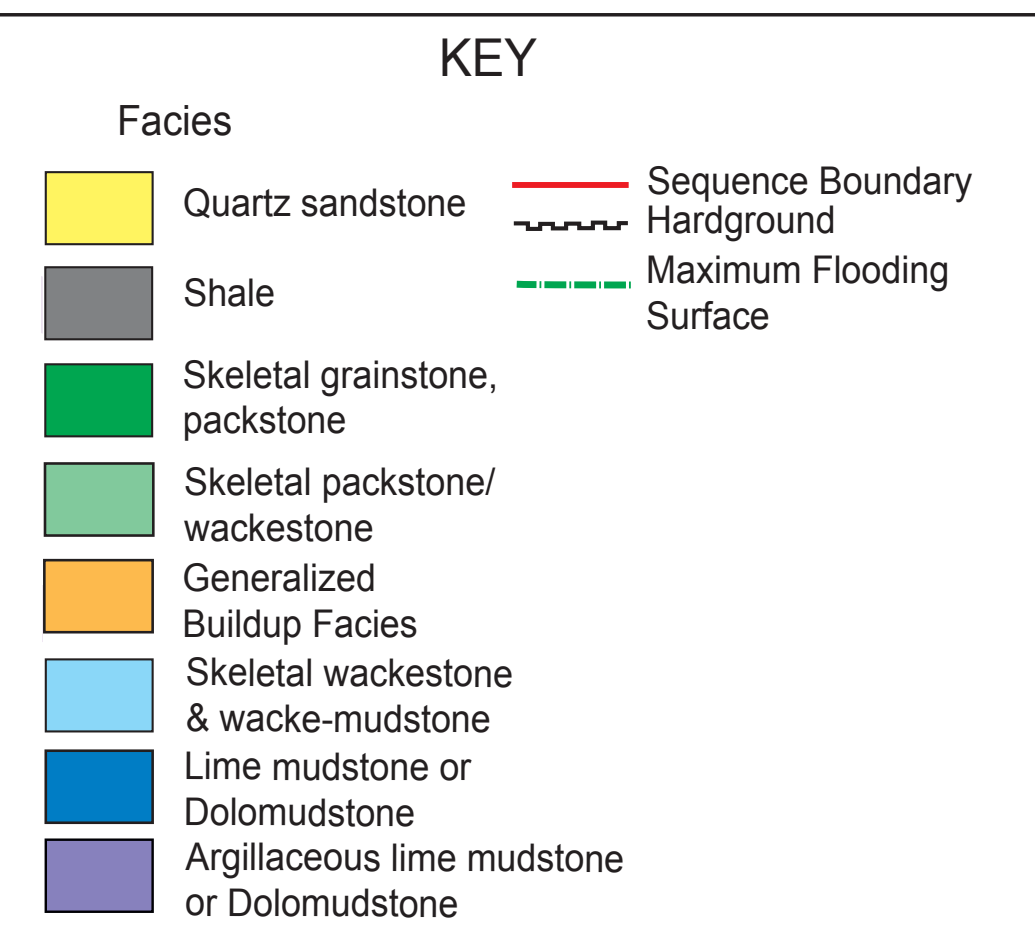


Fig. 9. Regional north-south sequence stratigraphic cross section showing interpretive, vertical and lateral facies succession based on continuous core data. Cross-section does not extend to the Fort Wayne Bank, and the buildup shown is an isolated mound.

Significant unconformities occur at the supersequence boundary on top of the Ordovician, and on top of the Silurian. Sequence boundaries at the bases of WS-1 to 3 are disconformities, but the others are conformable surfaces (probably transgressive surfaces), reflecting the relatively deeper water setting of much of the shelf. 
A

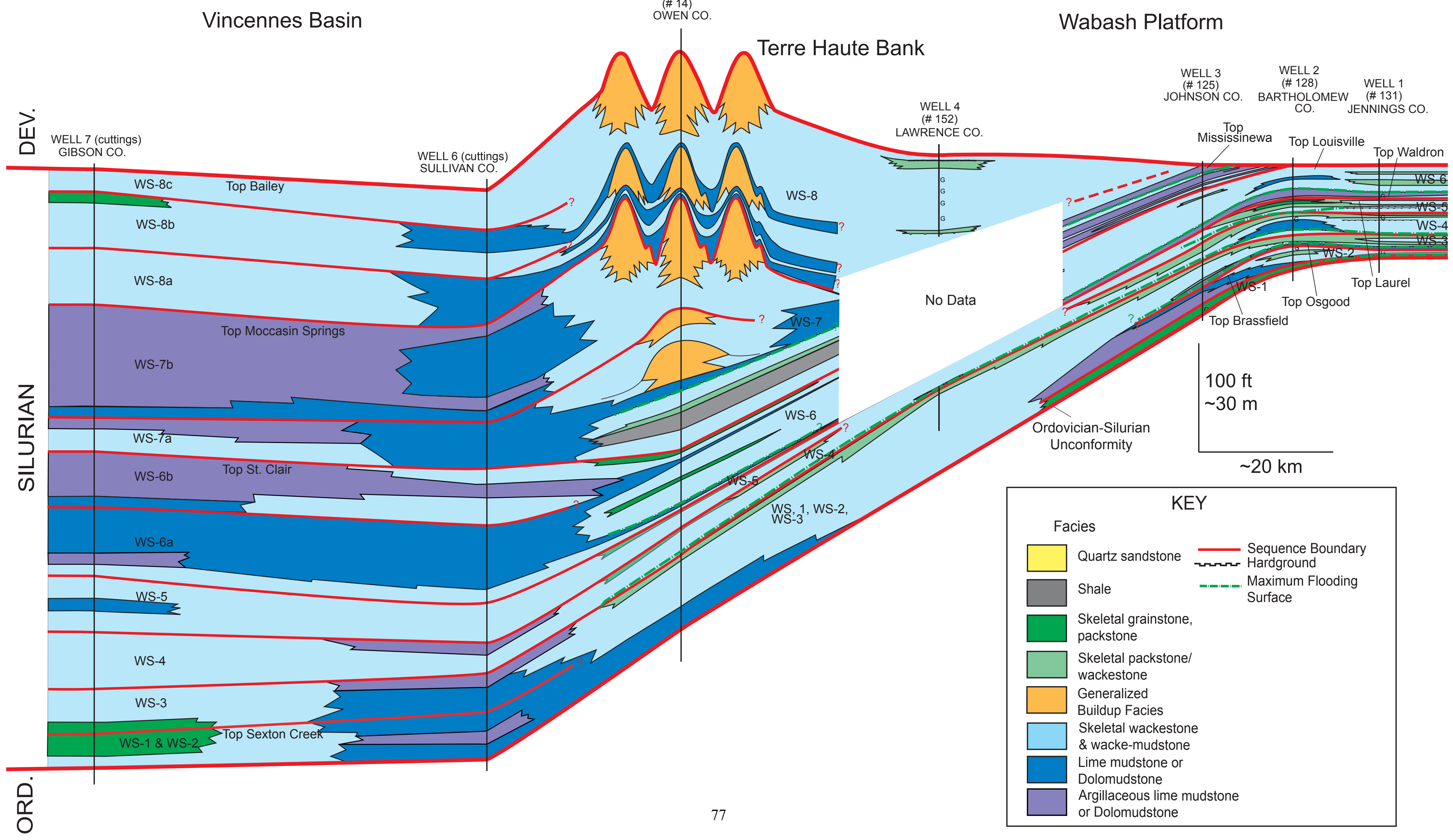


Fig. 10. Regional west-east sequence stratigraphic cross section showing interpreted vertical and lateral facies succession, based on continuous core data. Cross section extends from near Jessamine Dome, across Terre Haute Bank and into the Vincennes Basin. Wells 6 and 7 are from the ramp slop into the basin. See Figure 9 for further explanation. 


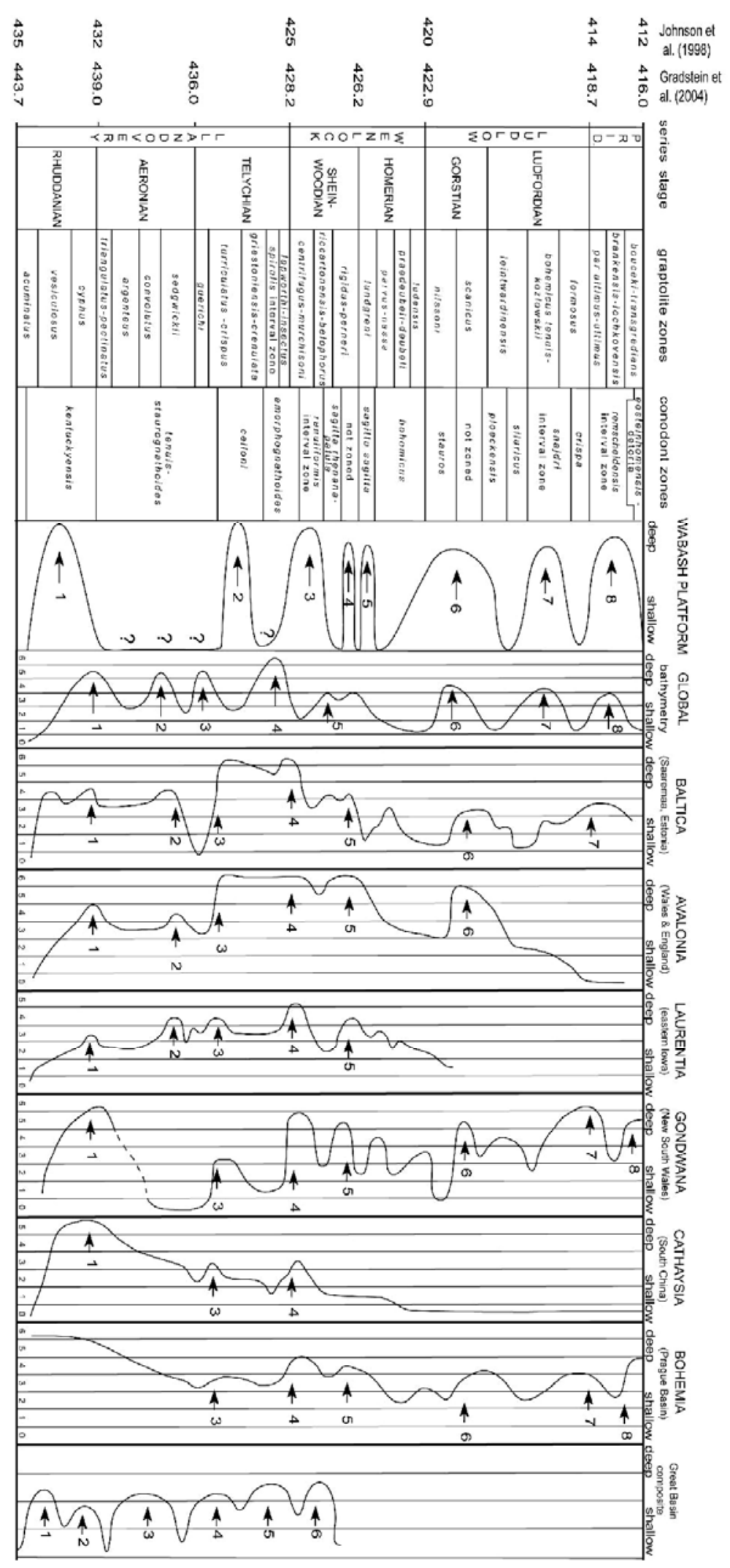


Fig. 11. Global and local sea level curves (Johnson, 1996), compared with Indiana sea level cycles (this study). Most of the Indiana sequences correlate with global eustatic curves and local curves from elsewhere. Exceptions included WS-2, which does not correlate with global or local curves and WS-3 which does not correlate with the global curve, but correlates with some local curves. 


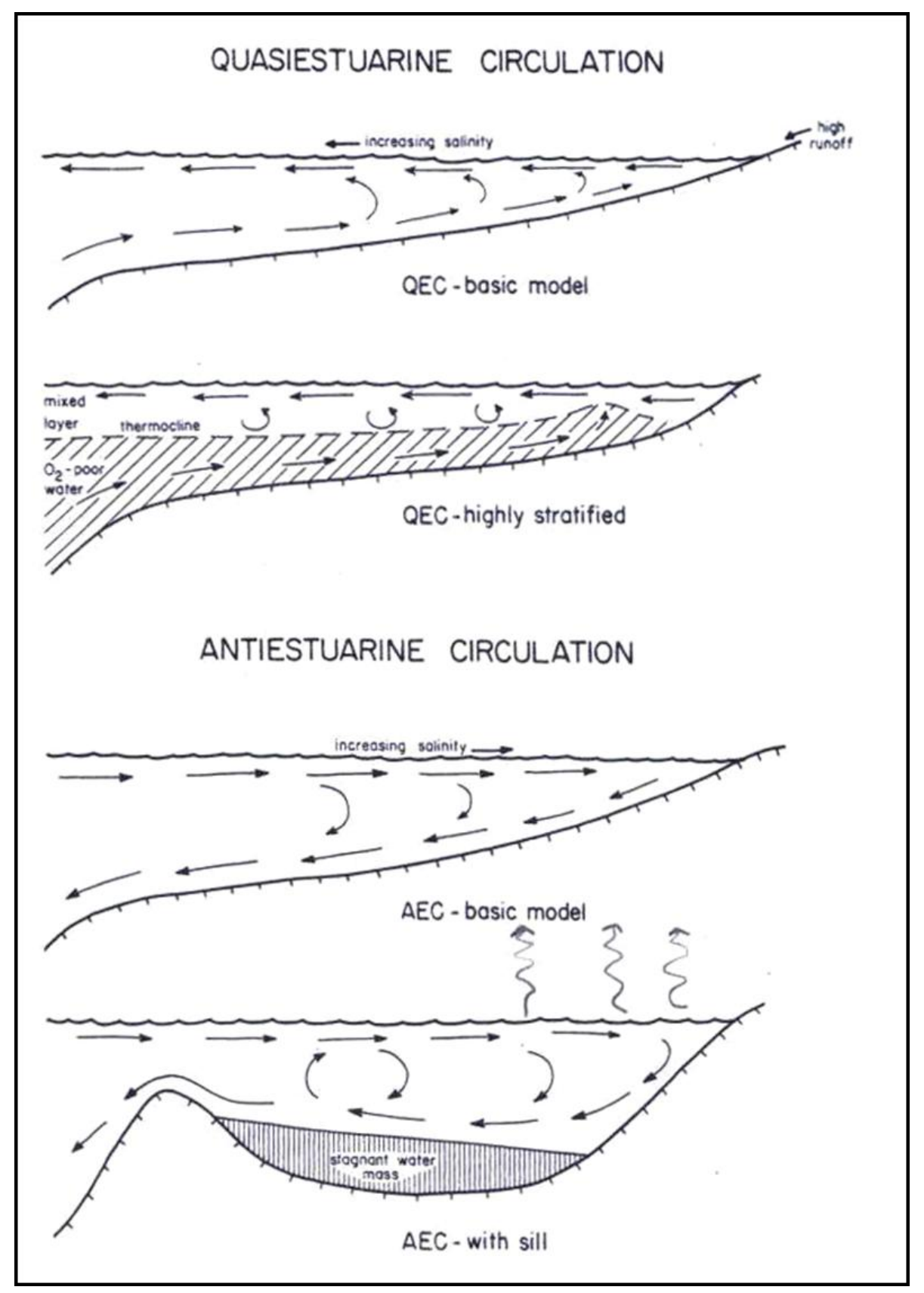

Fig. 12. Circulation models for (A) quasi-estuarine, which dominates during humid, cool climates in the Early Silurian and (B) anti-estuarine, which dominated during arid, warmer climates in the later Silurian (Witzke, 1987). Circulation could also switch from quasi-estuarine to anti-estuarine within third-order sequences (Cramer and Saltzman, 2007). 


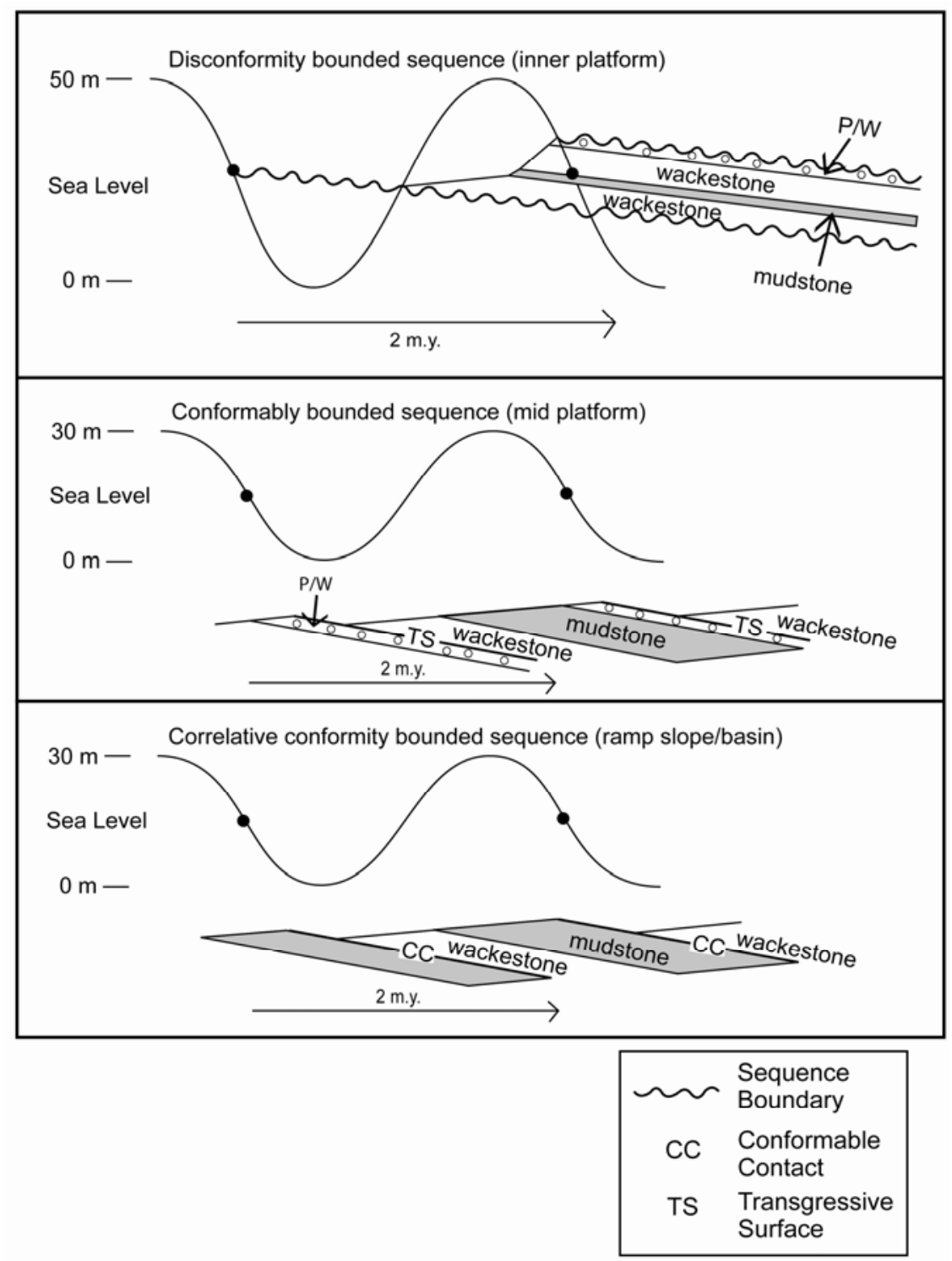

Fig. 13. Schematic origin of bounding surfaces. (A) Sea-level versus time plot showing origin of disconformable sequence boundaries which dominate sequences WS-1 to 3 . They formed on updip parts of the platform that was relatively high with respect to the sea level lowstand; sea level changes were some tens of meters. (B) Mapped conformable boundaries in sequences WS-4 to 8 on the Wabash platform probably 
developed on shallowest water facies at tops of sequences (lowstand deposits) and thus they represent transgressive surfaces. (C) In the basin where the data is limited to cuttings, the correlative conformities were placed arbitrarily beneath the shallowest water facies. 
Table 1. Silurian Carbonate Facies

\begin{tabular}{|c|c|c|c|c|c|c|c|}
\hline \multirow{2}{*}{$\begin{array}{l}\text { Facies } \\
\text { Depositional } \\
\text { Environment }\end{array}$} & \multirow{2}{*}{$\begin{array}{l}\text { Crinoid grainstone to } \\
\text { packstone sheets (High } \\
\text { energy sand shoals) }\end{array}$} & \multirow{2}{*}{\begin{tabular}{|l} 
Non-cherty, skeletal \\
wacke- packstone, \\
wackestone and wacke- \\
mudstone (deeper lagoon \\
to ramp slope)
\end{tabular}} & \multirow{2}{*}{$\begin{array}{l}\text { Cherty, skeletal } \\
\text { wackestone and wacke- } \\
\text { mudstone (dominantly } \\
\text { ramp slope) }\end{array}$} & \multirow{2}{*}{$\begin{array}{l}\text { Variably argillaceous } \\
\text { carbonate mudstone } \\
\text { (deepening lagoon, low } \\
\text { oxygen setting) }\end{array}$} & \multicolumn{3}{|l|}{ Buildup Facies } \\
\hline & & & & & $\begin{array}{l}\text { Stromatactis wackestone } \\
\text { and mudstone (deeper } \\
\text { mound setting) }\end{array}$ & $\begin{array}{l}\text { Stromatoporoid } \\
\text { wackestone and } \\
\text { floatstone (moderate } \\
\text { energy mound setting) }\end{array}$ & $\begin{array}{l}\text { Crinoidal rudstone, } \\
\text { grainstone and packstone } \\
\text { (in-situ to allochthonous, } \\
\text { high energy flank beds) }\end{array}$ \\
\hline \multirow{2}{*}{$\begin{array}{l}\text { Thickness anc } \\
\text { Stratigraphic } \\
\text { Occurrence }\end{array}$} & \multirow{2}{*}{$\begin{array}{l}3 \text { to } 5 \mathrm{~m} \text { thick sheet-like } \\
\text { units; occurs in Brassfield } \\
\text { Formation }\end{array}$} & \multirow{2}{*}{$\begin{array}{l}2 \text { to } 15 \mathrm{~m} \text { thick sheet-like } \\
\text { units; occurs throughout } \\
\text { section }\end{array}$} & \multirow{2}{*}{$\begin{array}{l}9 \text { to } 40 \mathrm{~m} \text { thick sheet-like } \\
\text { units; occurs throughout } \\
\text { section }\end{array}$} & \multirow{2}{*}{$\begin{array}{l}1 \text { to } 6 \mathrm{~m} \text { thick sheets; occur } \\
\text { in Osgood Shale, Waldron } \\
\text { Shale and Mississinewa } \\
\text { Shale Members }\end{array}$} & \multicolumn{3}{|c|}{1 to $15 \mathrm{~m}$ thick; associated with the Terre Haute Bank and individual buildups } \\
\hline & & & & & \multicolumn{2}{|c|}{ Probably mound-like units interfingering with flank facies } & Flank beds to mounds \\
\hline Color & medium gray & light to dark gray & white to light gray & $\begin{array}{l}\text { buff to brownish gray to light } \\
\text { gray }\end{array}$ & light gray & pale gray to white & pale gray to white \\
\hline \multirow[t]{2}{*}{$\begin{array}{l}\text { Depositional } \\
\text { Texture and } \\
\text { Grain Types }\end{array}$} & \multirow[t]{2}{*}{$\begin{array}{l}\text { medium to very coarse } \\
\text { grained, moderately to well } \\
\text { sorted, whole and } \\
\text { fragmented echinoderm, } \\
\text { lesser brachiopod, ostracod, } \\
\text { trilobite, mollusk, bryozoan } \\
\text { and rare glauconite grains }\end{array}$} & \multirow[t]{2}{*}{$\begin{array}{l}\text { fine- to coarse-grained, } \\
\text { poorly to moderately sorted, } \\
\text { whole and fragmented } \\
\text { echinoderms, lesser } \\
\text { brachiopod, mollusk, } \\
\text { ostracod, trilobite and } \\
\text { bryozoan debris and rare } \\
\text { peloids and glauconite }\end{array}$} & \multirow[t]{2}{*}{$\begin{array}{l}\text { rare to abundant fine- to } \\
\text { coarse-grained, poorly } \\
\text { sorted, whole and } \\
\text { fragmented echinoderms, } \\
\text { lesser brachiopod, ostracod, } \\
\text { and bryozoan debris with } \\
\text { rare to abundant diagenetic } \\
\text { chert and dolomitized matrix }\end{array}$} & \multirow[t]{2}{*}{$\begin{array}{l}\text { mud, fine- to medium- } \\
\text { grained, rare echinoderm, } \\
\text { brachiopod, ostracod, } \\
\text { bryozoan and indeterminate } \\
\text { skeletal debris, chert and } \\
\text { variably dolomitized fine } \\
\text { grained matrix }\end{array}$} & $\begin{array}{l}\text { fine- to medium-grained, } \\
\text { poorly to moderately sorted } \\
\text { whole and fragmented } \\
\text { echinoderms, stick } \\
\text { bryozoans and lesser } \\
\text { brachiopod, mollusk, } \\
\text { ostracod, Halysites debris } \\
\text { and Stromatactis }\end{array}$ & $\begin{array}{l}\text { small platey to sub- } \\
\text { spherical stromatoporoid, } \\
\text { rare crinoid, brachiopod, } \\
\text { ostracod, bryozoan and } \\
\text { some fragmented coral } \\
\text { pieces such as Favosites } \\
\text { and Halysites }\end{array}$ & $\begin{array}{l}\text { Gravel-sized and lesser } \\
\text { sand sized, poorly sorted } \\
\text { skeletal debris dominated } \\
\text { by crinoids, along with } \\
\text { lesser brachiopod, ostracod, } \\
\text { bryozoan and colonial coral. } \\
\text { Matrix is commonly } \\
\text { dolomitized skeletal silt-rich } \\
\text { mudstone }\end{array}$ \\
\hline & & & & & \multicolumn{3}{|l|}{ Variably dolomitized } \\
\hline $\begin{array}{l}\text { Sedimentary } \\
\text { Structures }\end{array}$ & massive & $\begin{array}{l}\text { massive, planar or wavy } \\
\text { bedded }\end{array}$ & $\begin{array}{l}\text { massive, planar to wavy } \\
\text { bedded, with variable } \\
\text { amounts of burrowing and } \\
\text { wavy argillaceous stringers }\end{array}$ & $\begin{array}{l}\text { planar to nodular bedded, } \\
\text { with minor amounts of } \\
\text { burrowing and argillaceous } \\
\text { dolomitic stringers }\end{array}$ & massive to bedded & massive to dipping beds & dipping flank beds \\
\hline $\begin{array}{l}\text { Processes and } \\
\text { Depths }\end{array}$ & $\begin{array}{l}\text { High production of skeletal } \\
\text { grains relative to mud } \\
\text { accumulation; wave-and } \\
\text { current-winnowed crinoidal } \\
\text { sand shoals, normal marine, } \\
\text { above fair-weather wave } \\
\text { base; }<10 \text { m water depths. }\end{array}$ & $\begin{array}{l}\text { moderate to low production } \\
\text { of skeletal grains relative to } \\
\text { mud production and } \\
\text { accumulation. Moderate to } \\
\text { low energy subtidal from } \\
\text { just below fair weather wave } \\
\text { base }>10 \mathrm{~m} \text { water depths } \\
\text { to storm wave base }<30 \mathrm{~m} \\
\text { water depths. Units } \\
\text { become more grainy with } \\
\text { upward shallowing }\end{array}$ & $\begin{array}{l}\text { Low energy ramp slope, } \\
\text { from } 35 \text { to } 100 \mathrm{~m} \text { water } \\
\text { depths, inhabited by } \\
\text { echinoderms, siliceous } \\
\text { sponges, moderate to low } \\
\text { grain production relative to } \\
\text { lime mud. Chert from } \\
\text { sponge spicules, possibly } \\
\text { associated with upwelling. }\end{array}$ & $\begin{array}{l}\text { Very low energy settings } \\
\text { below storm wave base } 35 \\
\text { to } 100 \mathrm{~m} \text { water depths; low } \\
\text { oxygen; stratified water } \\
\text { column, low grain } \\
\text { production relative to } \\
\text { abundant accumulation of } \\
\text { fines from terrestrial and } \\
\text { marine sources }\end{array}$ & $\begin{array}{l}\text { low energy mound facies } \\
\text { below storm wave base }> \\
30 \mathrm{~m} \text { water depths, below } \\
\text { depths of abundant crinoid } \\
\text { and stromatoporoid growth. } \\
\text { Marine cementation in } \\
\text { stromatactis cavities }\end{array}$ & $\begin{array}{l}\text { generally moderate energy } \\
\text { mounds inhabited by } \\
\text { laminar stromatoporoids, } \\
\text { moderate to high energy } \\
\text { settings; > } 30 \text { m water } \\
\text { depths }\end{array}$ & $\begin{array}{l}\text { high energy flank beds in } \\
\text { place of allochthonous } \\
\text { debris dominated by large } \\
\text { crinoids; leeward sides of } \\
\text { buildups; after shoaling to } \\
\text { wave base, marine } \\
\text { cementation common; } \\
\text { variable water depths }\end{array}$ \\
\hline
\end{tabular}


Table 2. Silurian Sequence Stratigraphy

\begin{tabular}{|c|c|c|c|c|c|c|c|}
\hline $\begin{array}{c}\text { Sequence and } \\
\text { age }\end{array}$ & $\begin{array}{l}\text { Lithostrat and sequence } \\
\text { thickness (meters) }\end{array}$ & Basal boundary & LST & Transgressive System Tract (TST) & $\begin{array}{l}\text { Maximum Flooding Surface } \\
\text { (MFS) }\end{array}$ & $\begin{array}{l}\text { Highstand System Tract (HST) (top may } \\
\text { include LST) }\end{array}$ & Parasequence \\
\hline \begin{tabular}{|l|} 
WS-1 \\
Rhuddanian to \\
mid-Aeronian
\end{tabular} & $\begin{array}{l}\text { Lower Brassfield/Lower Sexton } \\
\text { Creek; } 2 \mathrm{~m} \text { updip to } 6 \mathrm{~m} \\
\text { downdip }\end{array}$ & $\begin{array}{l}\text { Subtle erosional unconformity } \\
\text { updip above Ordovician quartz } \\
\text { silty dolomite and limestone, } \\
\text { locally laminated downdip. }\end{array}$ & None & \multicolumn{3}{|c|}{$\begin{array}{l}\text { TST and HST similar, dominated by glauconitic crinoid grainstone and packstone updip and locally cherty and commonly laminated lime } \\
\text { wackestone and mudstone downdip. Basal units are argillaceous locally. Farthest west well (Gibson County) has grainstone and packstone. }\end{array}$} & Simple parasequence \\
\hline $\begin{array}{l}\text { WS-2 upper } \\
\text { Telychian }\end{array}$ & $\begin{array}{l}\text { Upper Brassfield/Lee Creek } \\
\text { updip; Upper Sexton Creek } \\
\text { downdip; } 3 \mathrm{~m} \text { updip to over } 7 \mathrm{~m} \\
\text { downdip }\end{array}$ & $\begin{array}{l}\text { Updip non-depositional hiatus with } \\
\text { missing conodont zones. }\end{array}$ & None & \begin{tabular}{|l|} 
TST of wackestone with packstone storm beds \\
passes downdip to the north into locally cherty, \\
dolomudstone up into wackestone and to the west \\
into cherty lime mudstone then into cherty \\
wackestone. Farthest west well, Gibson County, \\
has grainstone and packstone.
\end{tabular} & $\begin{array}{l}\text { MFS updip on wacke-packstone } \\
\text { facies beneath wackestone. }\end{array}$ & $\begin{array}{l}\text { HST is commonly shallowing upward sequence from } \\
\text { wackestone or mudstone into wackestone or local } \\
\text { wacke-packstone (Wells } 8 \text { and } 9 \text { ). }\end{array}$ & $\begin{array}{l}\text { Two parasequences } \\
\text { locally developed } \\
\text { updip }\end{array}$ \\
\hline $\begin{array}{l}\text { WS-3 } \\
\text { lower } \\
\text { Sheinwoodian }\end{array}$ & $\begin{array}{l}\text { Osgood Shale and lower Laurel } \\
\text { Member, Salamonie Dolomite; } 4 \\
\text { m updip to } 10 \text { m downdip }\end{array}$ & $\begin{array}{l}\text { Sharp contact or hardground on } \\
\text { underlying sequence which has } \\
\text { internal sediment-filled cavities in } \\
\text { grainstone (exposure?) }\end{array}$ & None & $\begin{array}{l}\text { TST of argillaceous lime mudstone or } \\
\text { dolomudstone passes locally downdip into } \\
\text { transgressive wackestone (Wells 11, 12, 13 and } \\
\text { 14). }\end{array}$ & $\begin{array}{l}\text { MFS locally above transgressive } \\
\text { wackestone (Wells } 8,9,12,13 \text { and } \\
\text { 14); elsewhere coincident with } \\
\text { sequence boundary. }\end{array}$ & $\begin{array}{l}\text { HST is skeletal wackestone that locally grades into } \\
\text { wacke-packstone; thick lagoonal mudstone early in } \\
\text { HST and local mudstone in Well } 9 \text {. }\end{array}$ & $\begin{array}{l}\text { Generally one with } \\
\text { locally two } \\
\text { parasequences updip }\end{array}$ \\
\hline $\begin{array}{l}\text { WS-4 } \\
\text { upper } \\
\text { Sheinwoodian }\end{array}$ & $\begin{array}{l}\text { middle Laurel Member, } \\
\text { Salamonie Dolomite; } \\
\text { approximately } 7 \mathrm{~m} \text { thick }\end{array}$ & $\begin{array}{l}\text { Sharp to gradational contact with } \\
\text { local hardground (Well 9). }\end{array}$ & None & TST of thin wackestone updip, thickening downdip. & \begin{tabular}{|l|} 
MFS above transgressive \\
wackestone, beneath finer grain units \\
and on local hardground (Well 12) or \\
coincident with SB (Wells 2 and 3 ).
\end{tabular} & $\begin{array}{l}\text { HST is shallowing-upward wackestone to wacke- } \\
\text { packstone with local deeper lagoon cherty mudstone } \\
\text { (Wells } 8 \text { and 9) grading up into wackestone updip } \\
\text { and carbonate mudstone downdip in the cuttings. }\end{array}$ & $\begin{array}{l}\text { Generally one } \\
\text { parasequence updip } \\
\text { with two } \\
\text { parasequences } \\
\text { downdip }\end{array}$ \\
\hline \begin{tabular}{|l|} 
WS-5 \\
lower Homerian
\end{tabular} & $\begin{array}{l}\text { upper Laurel Member, } \\
\text { Salamonie Dolomite; } 7 \mathrm{~m} \text { updip } \\
\text { thinning westward to } 3 \mathrm{~m}\end{array}$ & $\begin{array}{l}\text { Sharp to gradational contact with } \\
\text { local hardground (Well 10). }\end{array}$ & None & $\begin{array}{l}\text { TST of wackestone both updip and downdip, locally } \\
\text { pinching out in updip Wells } 8 \text { and } 9 .\end{array}$ & $\begin{array}{l}\text { MFS developed above transgressive } \\
\text { wackestone and below finer grained } \\
\text { facies and is coincident with SB (Well } \\
\text { 8) and local hardgrounds (Well 1). }\end{array}$ & $\begin{array}{l}\text { HST is shallowing-upward; local mudstone (Wells } 8 \\
\text { and 9) to wackestone to wacke-packstone updip and } \\
\text { argillaceous mudstone grading up into wackestone } \\
\text { locally capped by grainstone/packstone (Wells } 11, \\
12 \text { and 13) downdip. Local hardground in upper part } \\
\text { of HST in Well } 8 \text { and } 11 \text {. }\end{array}$ & \begin{tabular}{|l} 
Generally one \\
parasequence local \\
with two \\
parasequences in \\
easterly wells (Wells \\
1 and 2)
\end{tabular} \\
\hline \begin{tabular}{|l|} 
WS-6 upper \\
Homerian, \\
Grostian, lower \\
Ludfordian
\end{tabular} & $\begin{array}{l}\text { Waldron Shale and Louisville } \\
\text { Limestone; } 9 \mathrm{~m} \text { updip to } 20 \mathrm{~m} \\
\text { downdip. May be } 2 \text { sequences } \\
\text { developed. }\end{array}$ & $\begin{array}{l}\text { Sharp contact or hardground } \\
\text { (Wells } 2 \text { and } 8 \text { ) or glauconite } \\
\text { (Well 1). }\end{array}$ & None & $\begin{array}{l}\text { TST of dominantly argillaceous mudstone, locally } \\
\text { basal wackestone grading up into argillaceous } \\
\text { mudstone (Wells } 10,11 \text { and 12). Local } \\
\text { hardgrounds (Well 12). }\end{array}$ & $\begin{array}{l}\text { MFS lies on or within argillaceous } \\
\text { mudstone (Waldron Shale) }\end{array}$ & $\begin{array}{l}\text { HST is upward shallowing wackestone to local } \\
\text { wacke-packstone cap. Local carbonate mudstone in } \\
\text { middle HST (Wells 2, 5, } 9 \text { and 10). }\end{array}$ & $\begin{array}{l}\text { Two to three } \\
\text { parasequences updip } \\
\text { to up to five } \\
\text { parasequences } \\
\text { downdip }\end{array}$ \\
\hline $\begin{array}{l}\text { WS-7 middle to } \\
\text { upper } \\
\text { Ludfordian }\end{array}$ & $\begin{array}{l}\text { Mississinewa Shale and lower } \\
\text { Liston Creek; Absent in } \\
\text { southeast (Wells } 1 \text { and 2) } \\
\text { thickens downdip to } 70 \mathrm{~m} \\
\text { downdip }\end{array}$ & Generally sharp contact. & None & $\begin{array}{l}\text { Updip, TST is upward deepening succession of } \\
\text { argillaceous mudstone and backstepping } \\
\text { wackestone. Downdip, TST is upward deepening } \\
\text { succession of argillaceous mudstone beneath } \\
\text { buildup in the north, and upward deepening shale } \\
\text { into wackestone in west. }\end{array}$ & \begin{tabular}{|l|} 
MFS downdip is minor flooding \\
surface within upper part of basal \\
argillaceous lime mudstone. MFS \\
lies in upper portion of argillaceous \\
mudstone updip and within or near \\
base of deeper water dolomudstone, \\
above lower part of buildup downdip.
\end{tabular} & $\begin{array}{l}\text { Updip, HST is argillaceous carbonate mudstone with } \\
\text { local wackestone. Downdip, HST consists of overall } \\
\text { succession of local buildup facies (Well 13) that } \\
\text { pass northward, south of Fort Wayne Bank } \\
\text { (downdip) into thick dolomudstone up into thin } \\
\text { wackestone. To west, HST is thin dolomudstone } \\
\text { passing updip into shallowing succession of stacked } \\
\text { buildup facies of Terre Haute Bank. }\end{array}$ & $\begin{array}{l}\text { At least four } \\
\text { parasequences updip } \\
\text { and at least eight } \\
\text { parasequences } \\
\text { downdip }\end{array}$ \\
\hline $\begin{array}{l}\text { WS-8 } \\
\text { Pridoli }\end{array}$ & $\begin{array}{l}\text { upper Liston Creek; Absent in } \\
\text { southeast (Wells } 1 \text { and } 2,3,8, \\
9,10) \text {, thickens to over } 45 \mathrm{~m} \\
\text { downdip }\end{array}$ & $\begin{array}{l}\text { Gradational contact except } \\
\text { generally above buildups, which is } \\
\text { sharp. }\end{array}$ & None & $\begin{array}{l}\text { TST is upward deepening succession of local } \\
\text { wackestone to dolomudstone (Well 11) or } \\
\text { laminated argillaceous carbonate mudstone and } \\
\text { wackestone. TST is difficult to define in Terre } \\
\text { Haute bank, but probably within interbedded } \\
\text { wackestone and mudstone low in sequence. }\end{array}$ & $\begin{array}{l}\text { MFS is difficult to define accurately. } \\
\text { Placed within laminated argillaceous } \\
\text { mudstones and dolomudstones and } \\
\text { at base of very cherty argillaceous } \\
\text { wackestone/mudstone to west, but } \\
\text { cannot trace through Terre Haute } \\
\text { buildup facies. }\end{array}$ & $\begin{array}{l}\text { HST is upward shallowing succession of carbonate } \\
\text { mudstone up into buildup facies. Away from buildup } \\
\text { (Well 14), upward shallowing mudstone to } \\
\text { wackestone. In Vincennes Basin, shallowing of } \\
\text { argillaceous cherty wacke-mudstone with increasing } \\
\text { number of interbedded crinoidal packstone beds } \\
\text { upsection. Top of sequence is Silurian-Devonian } \\
\text { unconformity. }\end{array}$ & $\begin{array}{l}\text { Up to six } \\
\text { parasequences } \\
\text { downdip }\end{array}$ \\
\hline
\end{tabular}


APPENDIX A: Well Locations

\begin{tabular}{|c|c|c|c|c|c|c|}
\hline $\begin{array}{l}\text { Well \# } \\
\text { (This } \\
\text { report) }\end{array}$ & $\begin{array}{l}\text { Well } \\
\# \\
\text { (IGS) }\end{array}$ & $\begin{array}{l}\text { IGS ID } \\
\#\end{array}$ & County & Township & Range & Section \\
\hline 1 & 131 & 127051 & Jennings & $5 \mathrm{~N}$ & $8 \mathrm{E}$ & 4 \\
\hline 2 & 128 & 125456 & Bartholomew & $8 \mathrm{~N}$ & $7 \mathrm{E}$ & 5 \\
\hline 3 & 125 & 125302 & Johnson & $11 \mathrm{~N}$ & $5 \mathrm{E}$ & 17 \\
\hline 4 & 152 & 107203 & Lawrence & $5 \mathrm{~N}$ & $2 \mathrm{E}$ & 20 \\
\hline 5 & 14 & 125617 & Owen & $9 \mathrm{~N}$ & $5 \mathrm{~W}$ & 21 \\
\hline 6 & N/A & 161244 & Sullivan & $8 \mathrm{~N}$ & $9 \mathrm{~W}$ & 36 \\
\hline 7 & $\mathrm{~N} / \mathrm{A}$ & 132162 & Gibson & $3 \mathrm{~S}$ & $14 \mathrm{~W}$ & 13 \\
\hline 8 & 493 & 146760 & Shelby & $14 \mathrm{~N}$ & $7 \mathrm{E}$ & 26 \\
\hline 9 & 481 & 145914 & Rush & $15 \mathrm{~N}$ & $8 \mathrm{E}$ & 24 \\
\hline 10 & 494 & 126571 & Marion & $15 \mathrm{~N}$ & $3 \mathrm{E}$ & 25 \\
\hline 11 & 113 & 126700 & Marion & $17 \mathrm{~N}$ & $4 \mathrm{E}$ & 20 \\
\hline 12 & 472 & 126648 & Boone & $17 \mathrm{~N}$ & $2 \mathrm{E}$ & 5 \\
\hline 13 & 736 & 158072 & Howard & $23 \mathrm{~N}$ & $5 \mathrm{E}$ & 30 \\
\hline 14 & 416 & 147606 & Wabash & $27 \mathrm{~N}$ & $6 \mathrm{E}$ & 55 \\
\hline
\end{tabular}


APPENDIX B: Thin Section Descriptions 


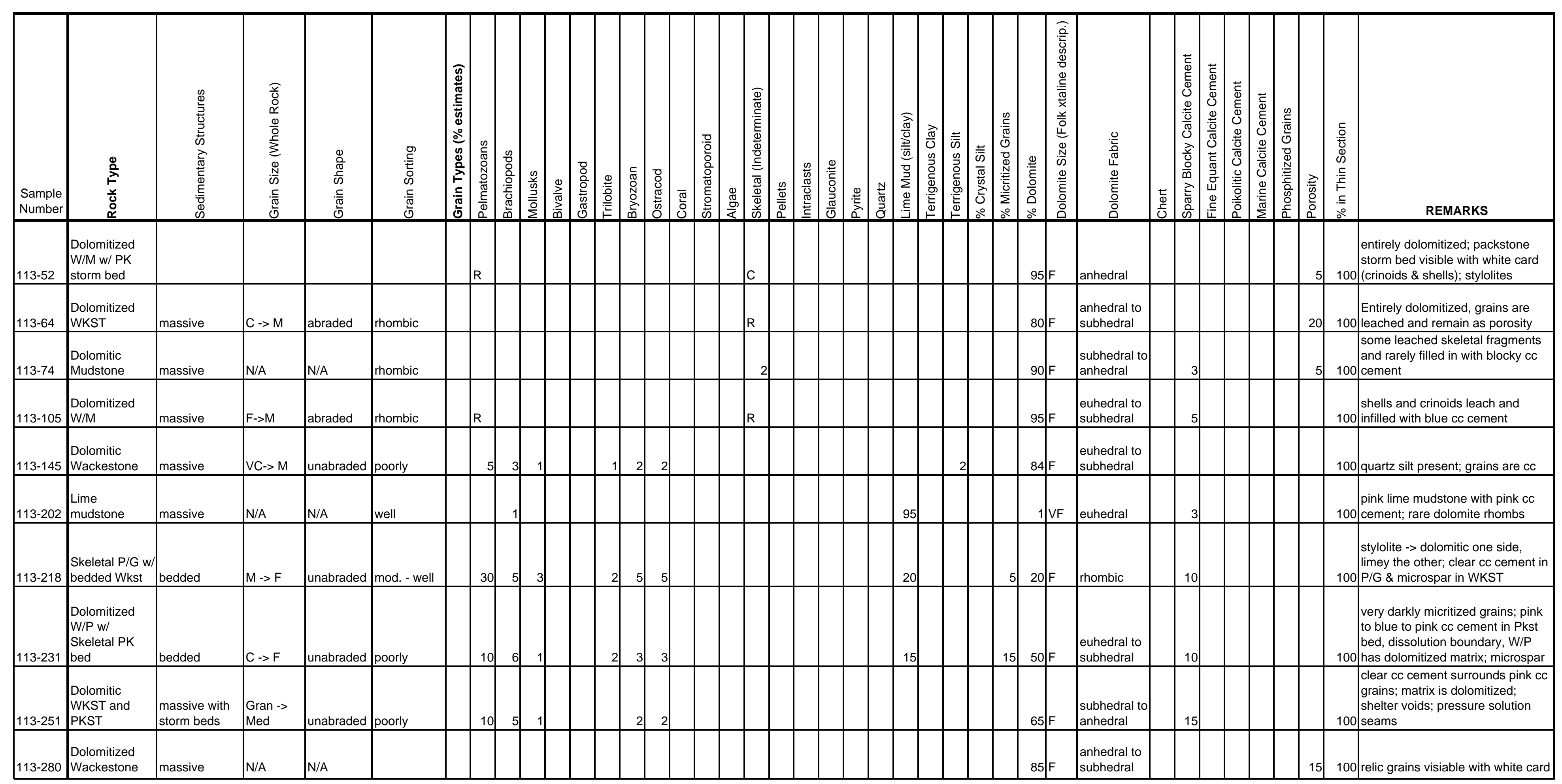




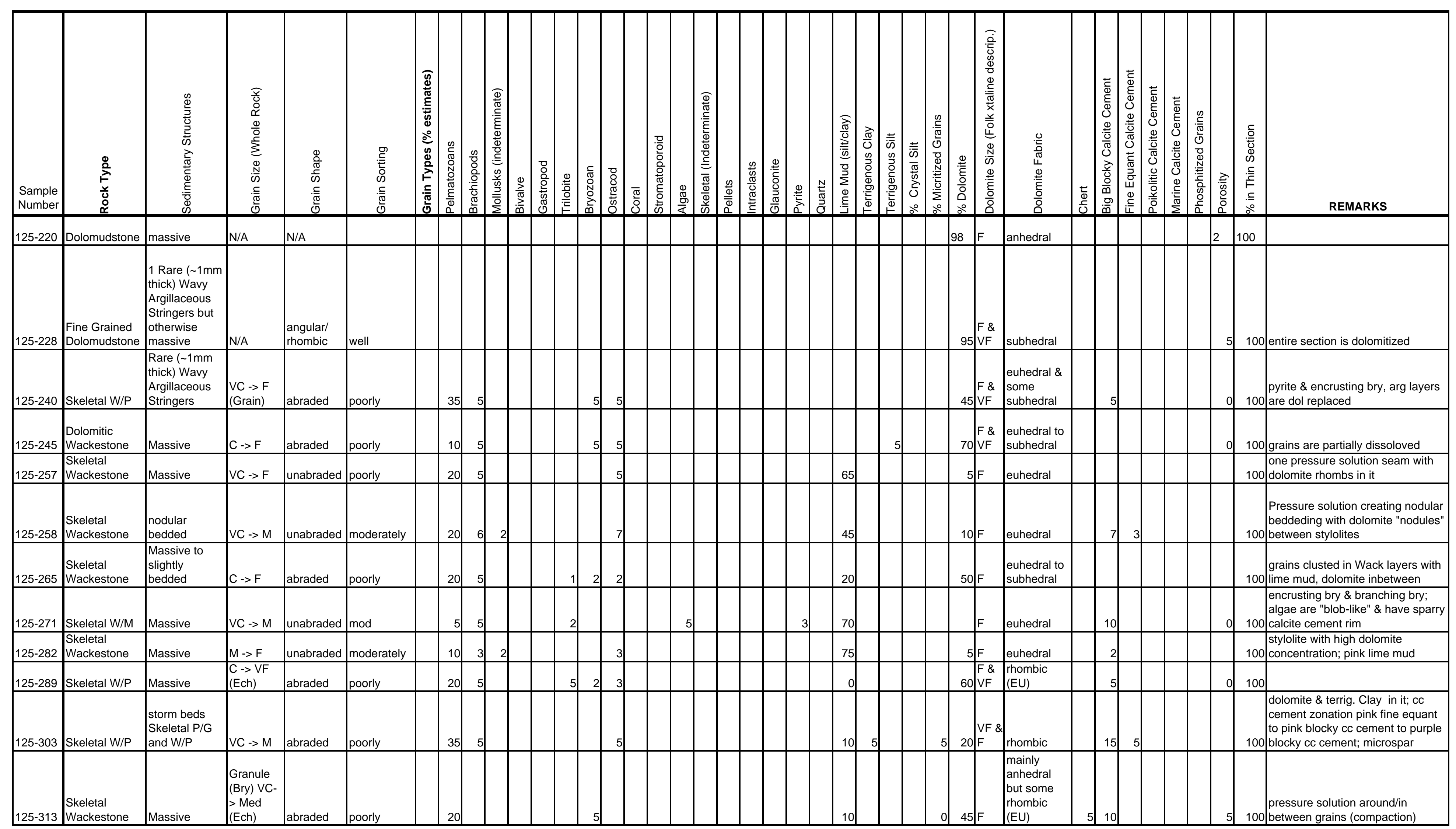




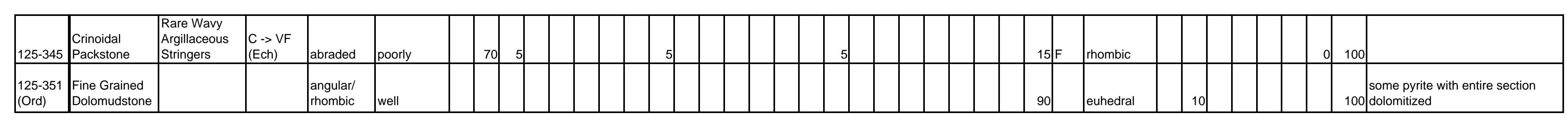




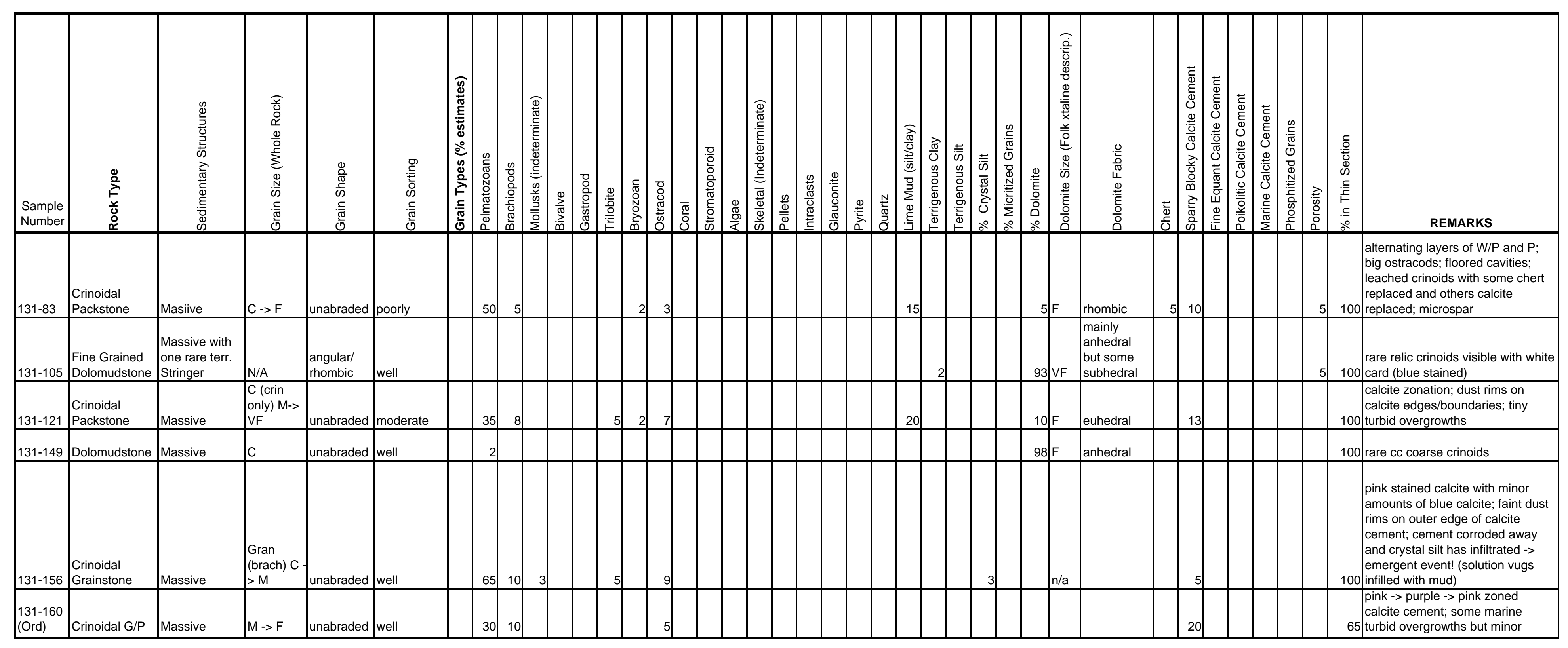




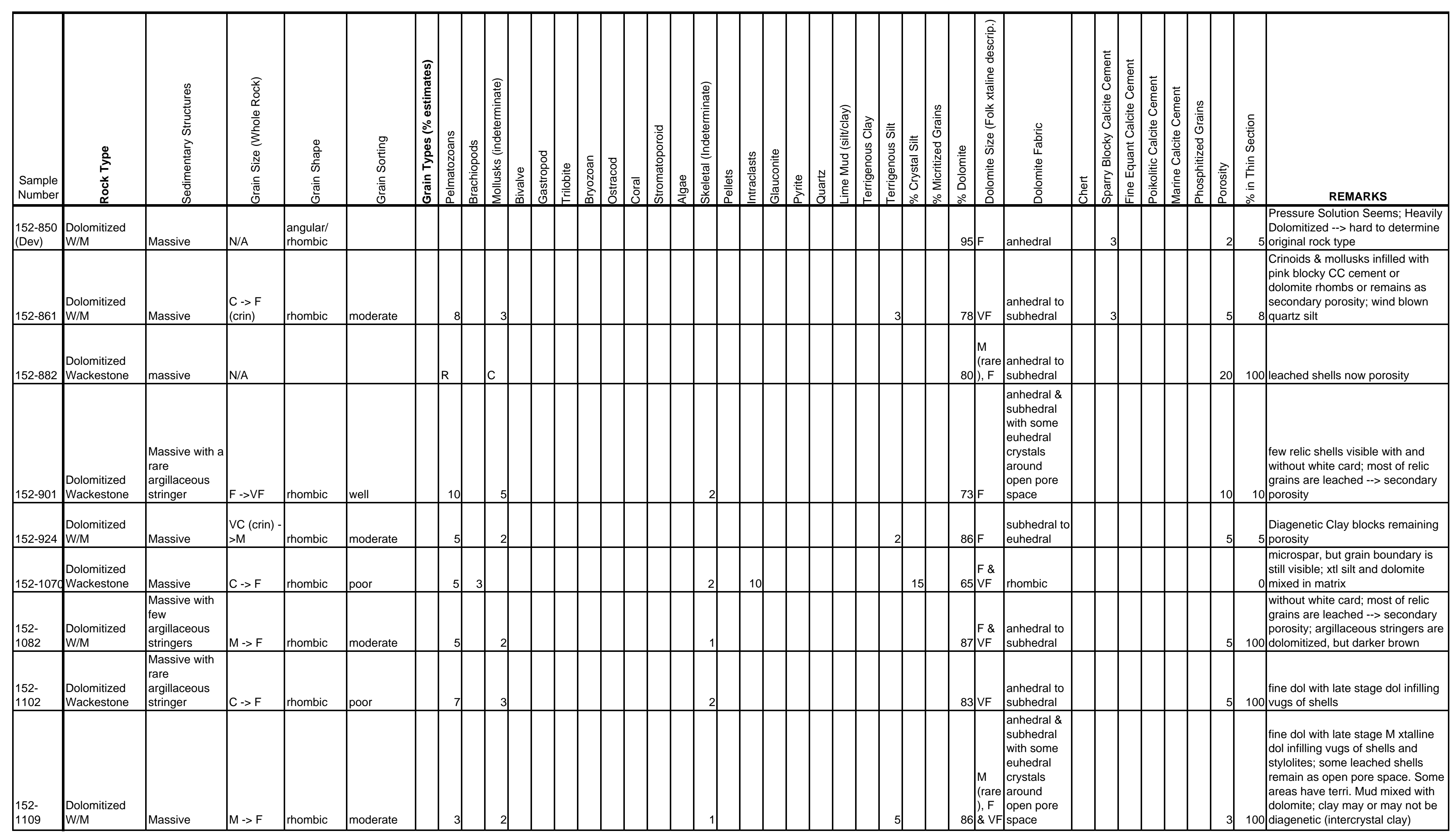




\begin{tabular}{|c|c|c|c|c|c|c|c|c|c|c|c|c|c|c|c|c|c|c|c|c|c|c|c|c|c|c|c|c|c|c|c|c|c|c|c|c|c|c|c|}
\hline $\begin{array}{l}\text { Sample } \\
\text { Number }\end{array}$ & 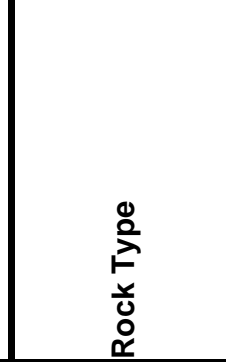 & 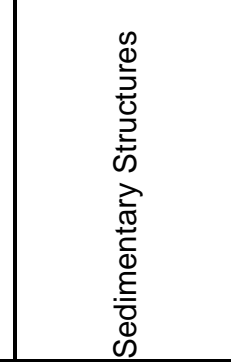 & 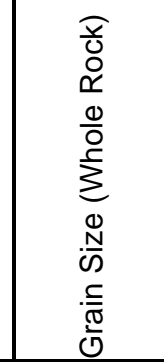 & $\begin{array}{l}\frac{0}{0} \\
\frac{\pi}{\pi} \\
\frac{\pi}{0} \\
\frac{5}{\pi} \\
\frac{\pi}{0}\end{array}$ & 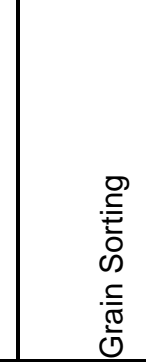 & 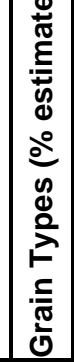 & 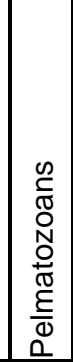 & \begin{tabular}{|l|} 
\\
\\
$\frac{0}{0}$ \\
0 \\
.0 \\
.$\frac{0}{\bar{c}}$ \\
$\frac{0}{0}$ \\
$\frac{0}{0}$
\end{tabular} & 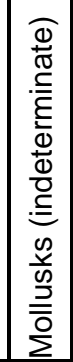 & 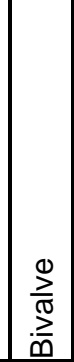 & \begin{tabular}{|l|l} 
\\
0 \\
0 \\
0 \\
0 \\
0 \\
$\tilde{0}$ \\
0 \\
\end{tabular} & 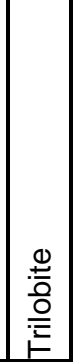 & 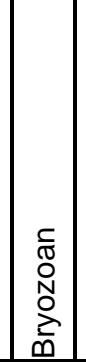 & 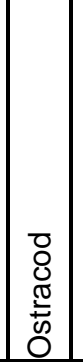 & 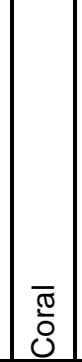 & 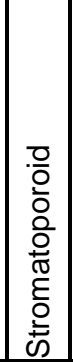 & 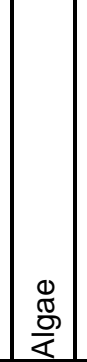 & 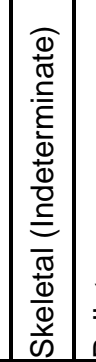 & 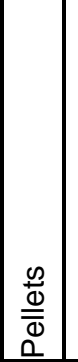 & 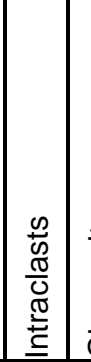 & 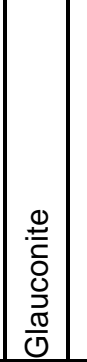 & 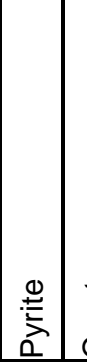 & 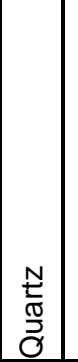 & 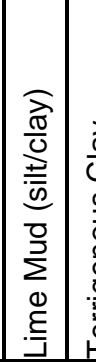 & 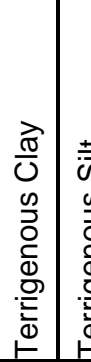 & 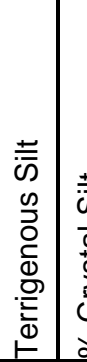 & 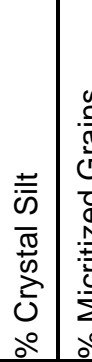 & 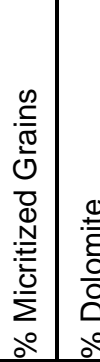 & 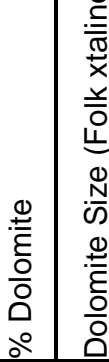 & 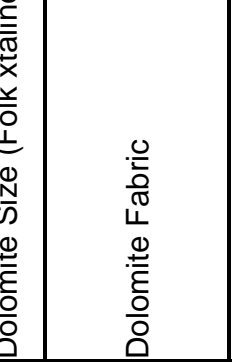 & 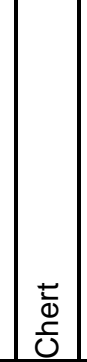 & 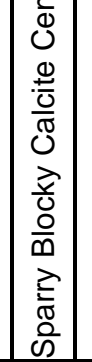 & 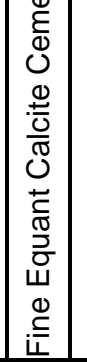 & 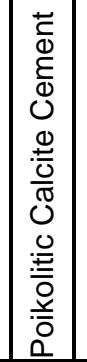 & 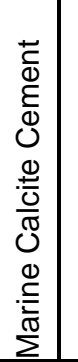 & 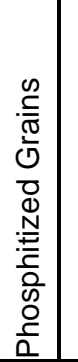 & $\begin{array}{l}2 \\
\frac{7}{0} \\
\frac{0}{0} \\
0 \\
0\end{array}$ & 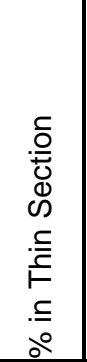 & REMARKS \\
\hline 416-38 & Skeletal W/M & $\begin{array}{l}\begin{array}{l}\text { massive with } \\
\text { chert }\end{array} \\
\end{array}$ & $C \rightarrow F$ & abraded & poorly & & 4 & 3 & & & & & 2 & 2 & & & & & & & & & & 44 & & & & & $10 \mathrm{~F}$ & euhedral & 30 & 5 & & & & & & 100 & $\begin{array}{l}\text { microspar; chert is half of thin } \\
\text { section }\end{array}$ \\
\hline 416-53 & \begin{tabular}{|l|} 
Skeletal \\
Wackestone
\end{tabular} & massive & Gran $->M$ & abraded & poorly & & 15 & 5 & 2 & & & & 3 & 5 & & & & & & & & & & 45 & & & & & $25 \mathrm{~F}$ & euhedral & & & & & & & & 100 & $\begin{array}{l}\text { matrix is dolomitized heavily in } \\
\text { places; microspar in other places }\end{array}$ \\
\hline $416-60$ & Dolomudstone & massive & N/A & N/A & & & & & & & & & & & & & & & & & & & & & & 5 & & & $95 / F$ & anhedral & & & & & & & & 100 & quartz silt; stained blue \\
\hline 416-71 & Lime Mudstone & massive & N/A & N/A & & & & & & & & & & & & & & $\mathrm{R}$ & & & & & & 95 & & & & & & & & & & & & & 5 & 100 & $\begin{array}{l}\text { some shell fragments leached as } \\
\text { porosity }\end{array}$ \\
\hline $416-148$ & Dolomudstone & laminated & N/A & N/A & & & & & & & & & & & & & & & & & & & & & & 5 & & & 95 & & & & & & & & & 100 & $\begin{array}{l}->\text { quartz \& mica pieces; } \\
\text { suggestion of low angle cross } \\
\text { ripples }\end{array}$ \\
\hline $416-185$ & $\begin{array}{l}\text { Dolomitic } \\
\text { Wackestone }\end{array}$ & massive & $V C \rightarrow M$ & abraded & poorly & & 20 & 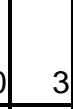 & & & & & 2 & 5 & & & & & & & & & & 15 & & & & & $55 \mathrm{~F}$ & $\begin{array}{l}\text { euhedral to } \\
\text { subhedral }\end{array}$ & & & & & & & & 100 & $\begin{array}{l}\text { matrix is dolomitized in regions \& } \\
\text { chewing into lime mud \& grains }\end{array}$ \\
\hline 416-207 & Dolomitic W/M & massive & $V C \rightarrow M$ & unabraded & poorly & & 15 & 2 & & & & & & 3 & & & & & & & & & & & & & & & $75 \mathrm{~F}_{\mathrm{F}}$ & $\begin{array}{l}\text { anhedral to } \\
\text { subhedral }\end{array}$ & & & & & & & 5 & 100 & grains still cc; rest is dolomitized \\
\hline 416-218 & Dolomudstone & massive & N/A & N/A & & & & & & & & & & & & & & & & & & & & & 5 & & & & $90 \mathrm{~F}$ & anhedral & & & & & & & 5 & 100 & \begin{tabular}{|l} 
completely dolomitized; cant see \\
relic grains; severl stylolites
\end{tabular} \\
\hline 416-273 & Dolomudstone & massive & N/A & N/A & & & & & & & & & & & & & & & & & & & & & & & & & $100 / F$ & anhedral & & & & & & & & 100 & \\
\hline 416-299 & Dolomitic W/M & massive & N/A & N/A & & & $R$ & & & & & & & & & & & & & & & & & & 5 & & & & $90 / \mathrm{F}$ & anhedral & & & & & & & 5 & 100 & $\begin{array}{l}\text { stylolites; leached grains now } \\
\text { porosity }\end{array}$ \\
\hline 416-307 & Dolomitic W/M & $\begin{array}{l}\text { nodular } \\
\text { bedded }\end{array}$ & N/A & N/A & & & $R$ & & & & & & & & & & & & & & & & & & 5 & & & & $95 \mathrm{~F}_{\mathrm{F}}$ & anhedral & & & & & & & 0 & 100 & $\begin{array}{l}\text { causing nodules to form (mud } \\
\text { concentrating around dolomite }\end{array}$ \\
\hline 416-341 & Dolomudstone & massive & N/A & N/A & & & & & & & & & & & & & & $R$ & & & & & & & & & & & $98 \mathrm{~F}_{\mathrm{F}}$ & anhedral & & & & & & & 2 & 100 & leached shells now porosity \\
\hline 416-364 & Dolomitic W/M & massive & N/A & N/A & & & & & & & & & & & & & & $\mathrm{R}$ & & & & & & & & & & & $90 / \mathrm{F}$ & anhedral & & & & & & & 10 & & $\begin{array}{l}\text { leached shells now porosity; } \\
\text { stylolites }\end{array}$ \\
\hline
\end{tabular}




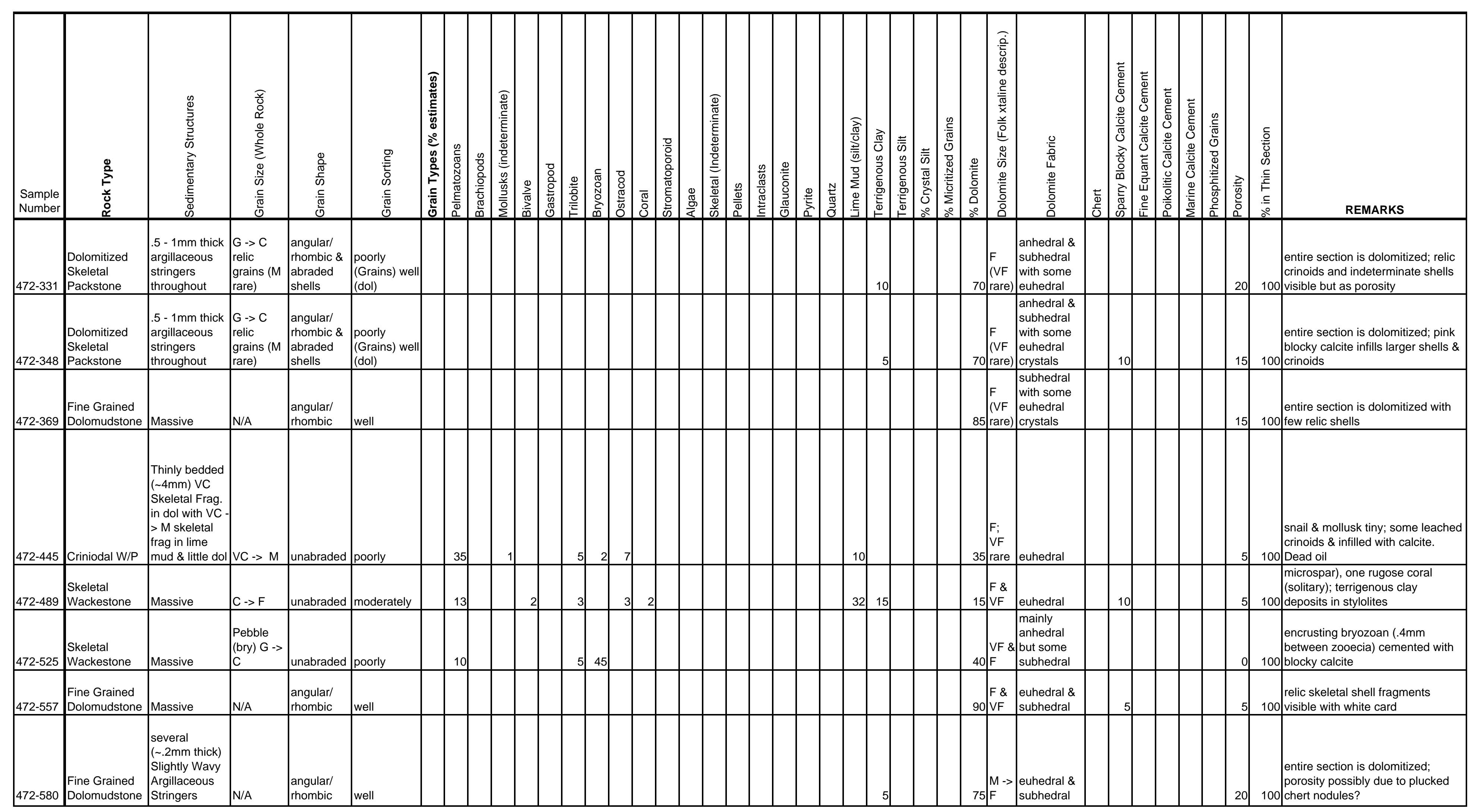




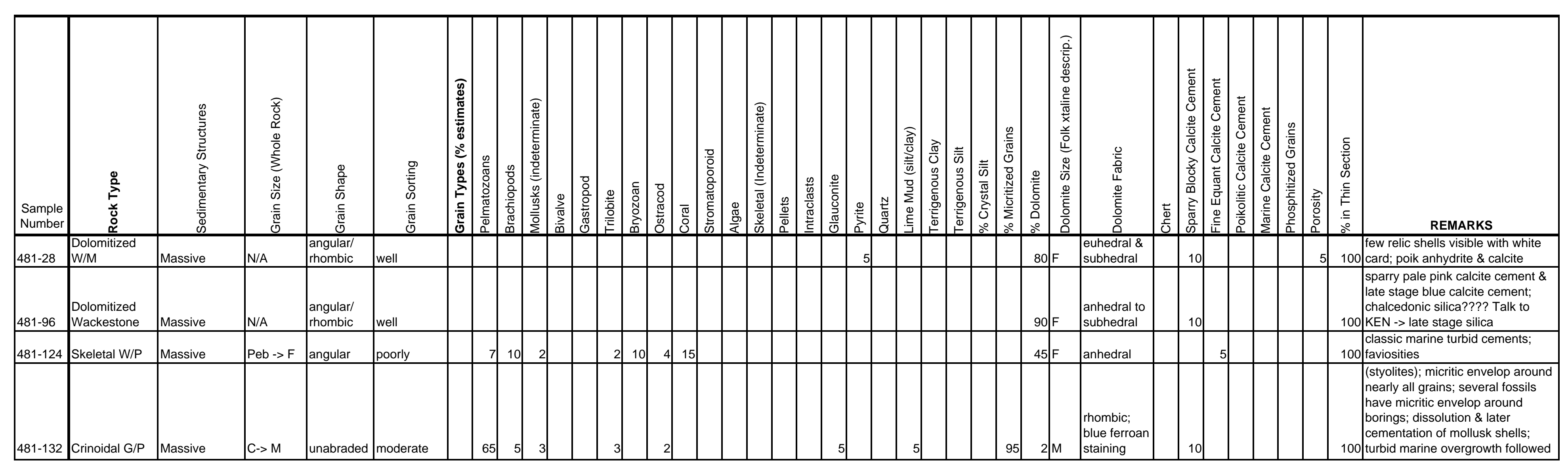




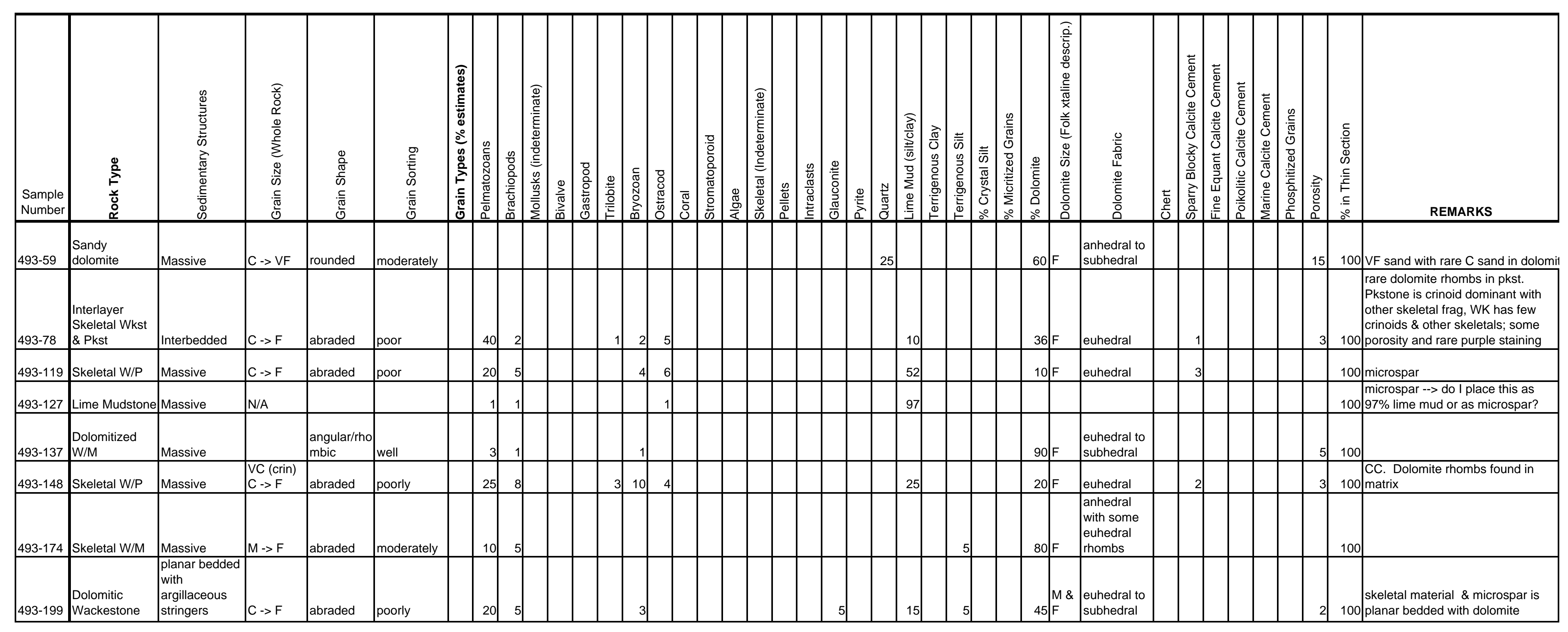




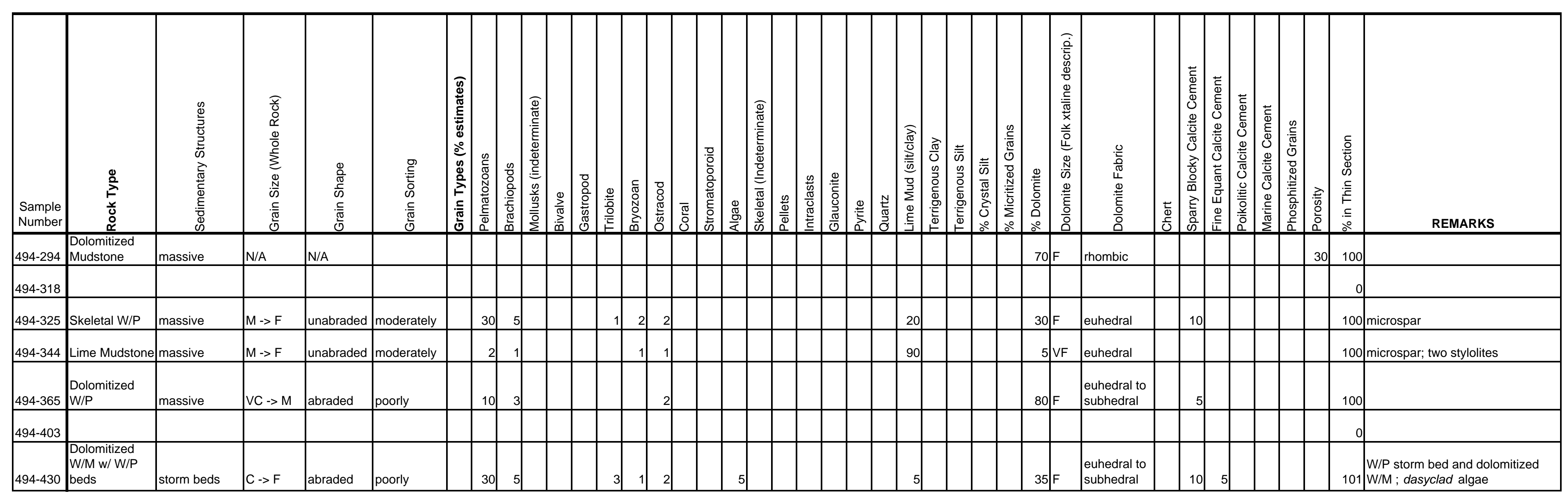




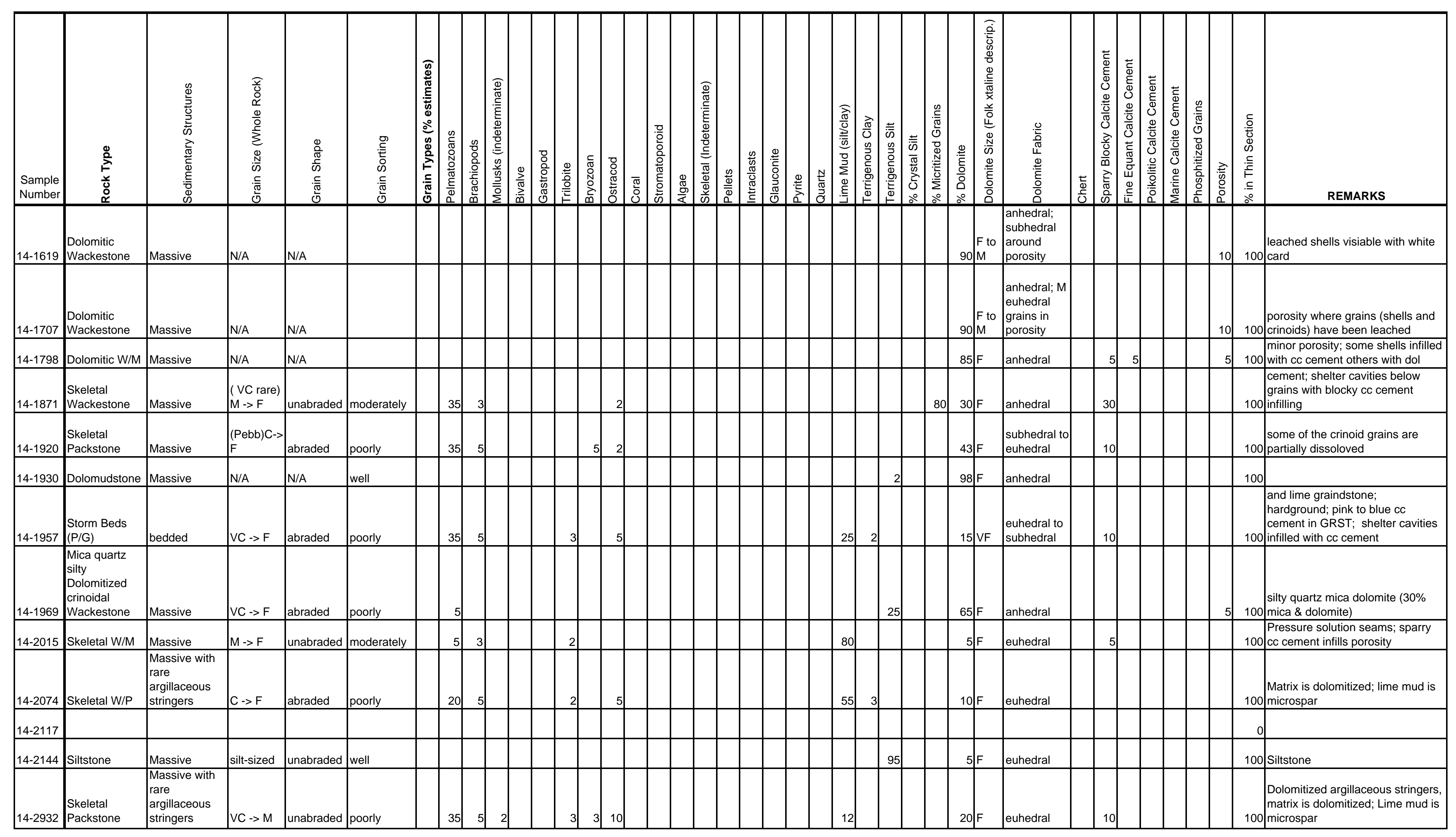




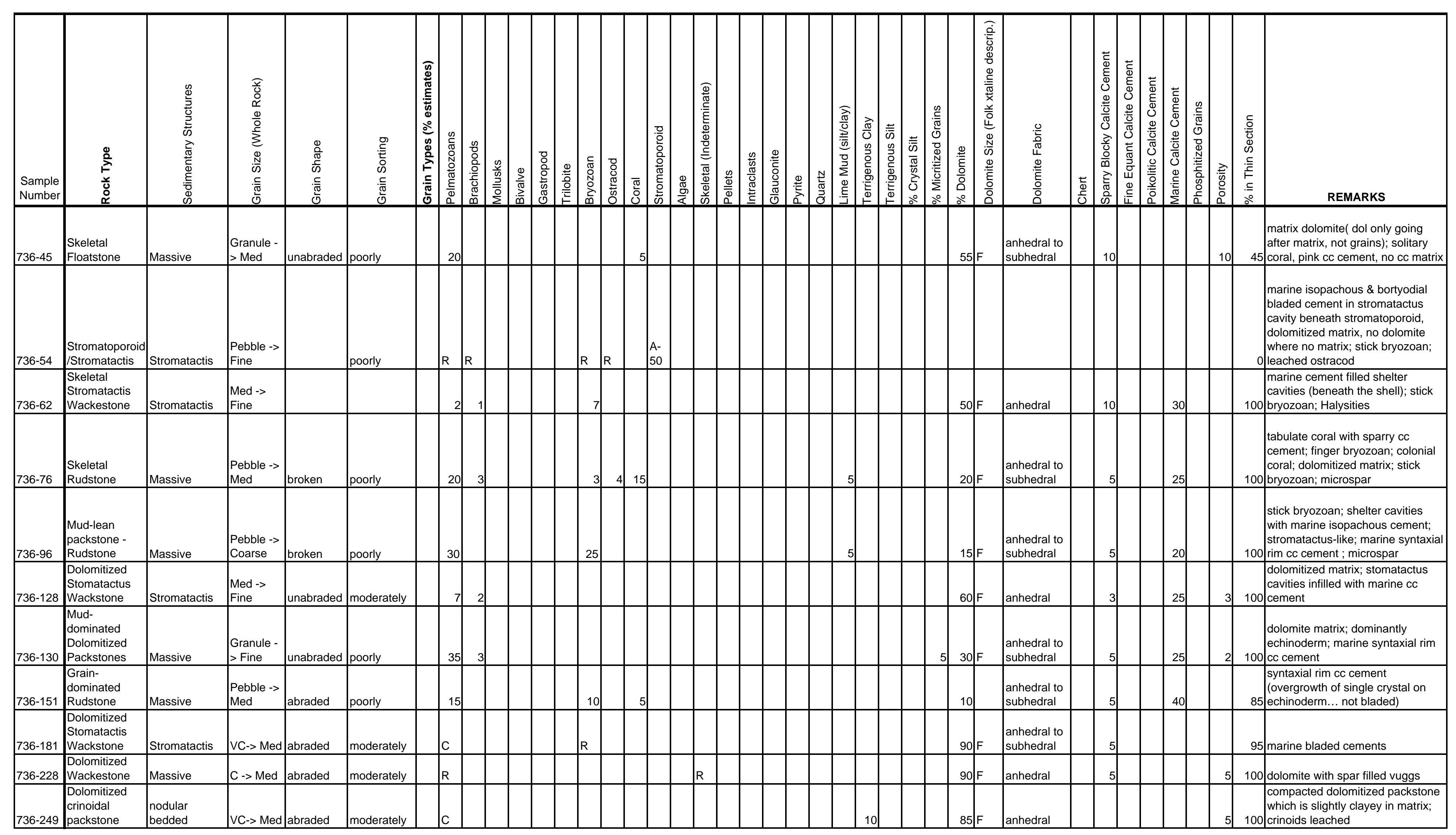




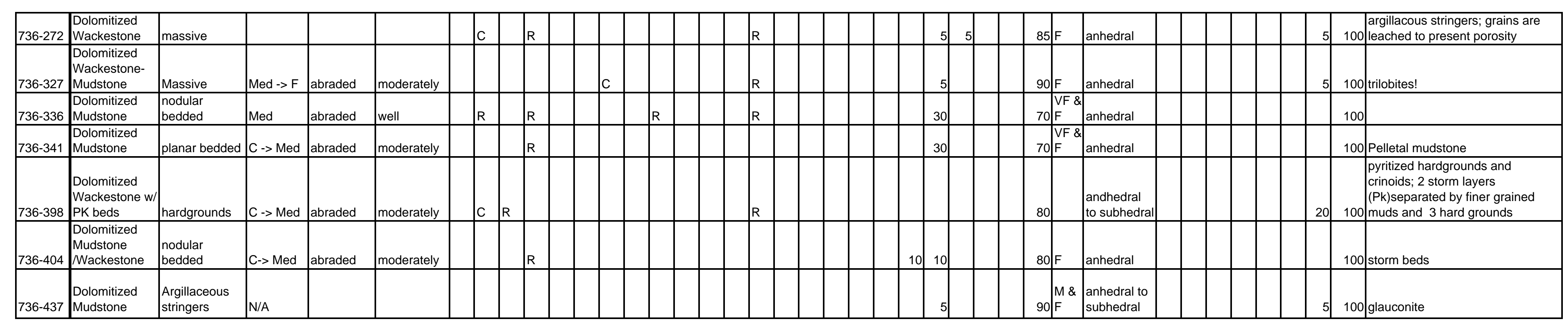




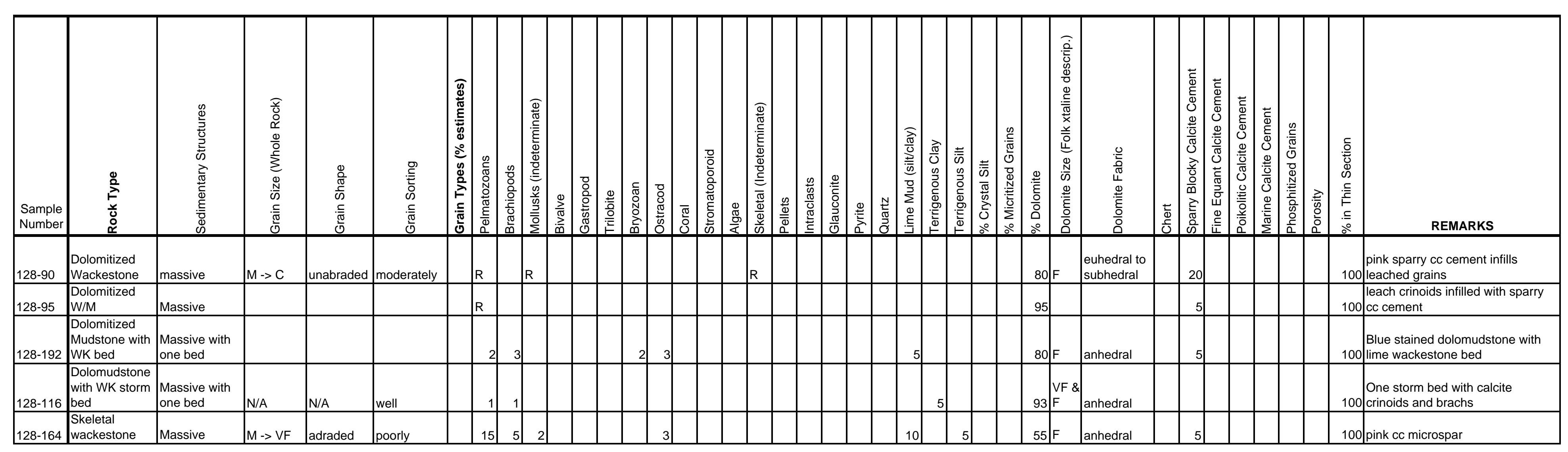

